Key Words: Sludge, Chemical Cleaning,

Oxalic Acid, Nitric Acid

Retention: Permanent

\title{
WASTE TANK HEEL CHEMICAL CLEANING SUMMARY
}

Kofi Adu-Wusu

Mark J. Barnes

Ned E. Bibler

Joel R. Cantrell

Fernando F. Fondeur

Barbara A. Hamm

Connie C. Herman

David T. Hobbs

Edward T. Ketusky

Mareesa Singleton

Mary E. Stallings

W. Edward Stevens

Bruce J. Wiersma

September 9, 2003

Westinghouse Savannah River Company Savannah River Site Aiken, SC 29808

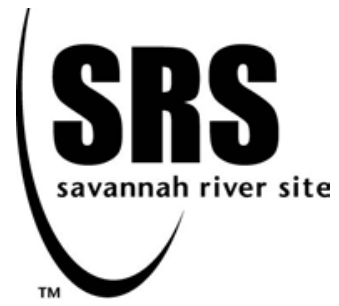


This document was prepared in conjunction with work accomplished under Contract No. DE-AC09-96SR18500 with the U. S. Department of Energy.

\section{DISCLAIMER}

This report was prepared as an account of work sponsored by an agency of the United States Government. Neither the United States Government nor any agency thereof, nor any of their employees, makes any warranty, express or implied, or assumes any legal liability or responsibility for the accuracy, completeness, or usefulness of any information, apparatus, product or process disclosed, or represents that its use would not infringe privately owned rights. Reference herein to any specific commercial product, process or service by trade name, trademark, manufacturer, or otherwise does not necessarily constitute or imply its endorsement, recommendation, or favoring by the United States Government or any agency thereof. The views and opinions of authors expressed herein do not necessarily state or reflect those of the United States Government or any agency thereof.

This report has been reproduced directly from the best available copy.

Available for sale to the public, in paper, from: U.S. Department of Commerce, National Technical Information Service, 5285 Port Royal Road, Springfield, VA 22161, phone: (800) 553-6847, fax: (703) 605-6900

email: orders@ntis.fedworld.gov

online ordering: http://www.ntis.gov/help/index.asp

Available electronically at http://www.osti.gov/bridge

Available for a processing fee to U.S. Department of Energy and its contractors, in paper, from: U.S. Department of Energy, Office of Scientific and Technical Information, P.O. Box 62, Oak Ridge, TN 37831-0062,

phone: (865)576-8401,

fax: (865)576-5728

email: $\underline{\text { reports@ adonis.osti.gov }}$ 
WSRC-TR-2003-00401 


\section{TABLE OF CONTENTS}



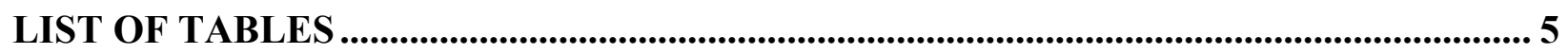

1.0 EXECUTIVE SUMMARY ............................................................................................... 7

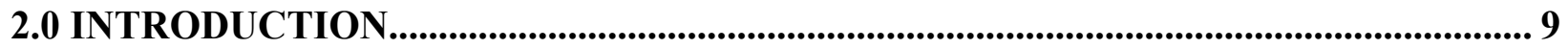

3.0 HIGH LEVEL WASTE DESCRIPTION ........................................................................... 10

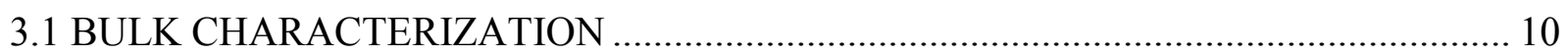

3.2 WASTE STREAM-SPECIFIC CHARACTERIZATION .............................................. 11

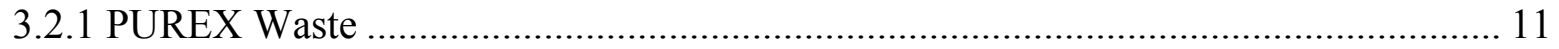



3.3 TANK CONSIDERATIONS FOR HEEL REMOVAL …………................................... 13

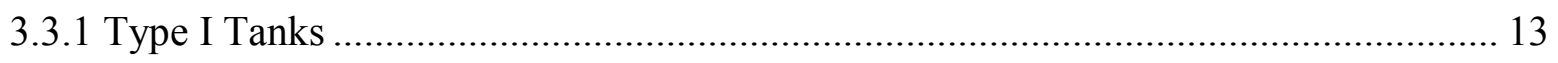





4.0 CHEMICAL CLEANING AGENTS ............................................................................... 18



4.1.1 Chemical Cleaning of Porous Metal Filters .............................................................. 19

4.1.2 Laboratory Tests in Support of Tank 16H Heel Cleaning ............................................. 22

4.1.2.1 Short Term Tank 16H Sludge Tests.................................................................. 22

4.1.2.2 Tests of Oxalic Acid with Simulated Sludge Materials .......................................... 23

4.1.2.3 Long Term Contact Tests with Actual Tank 16H Sludge...................................... 24

4.1.3 Digestion Tests with Tank 16H Sludge ……………................................................ 25

4.1.4 Oxalic Acid Cleaning of Tank 24H ....................................................................... 25

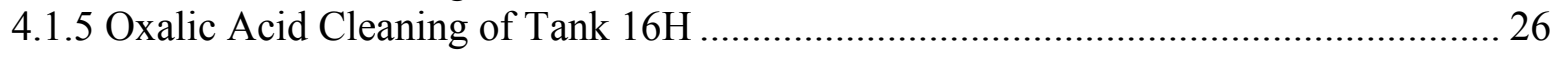

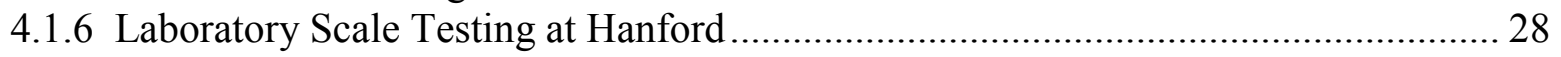

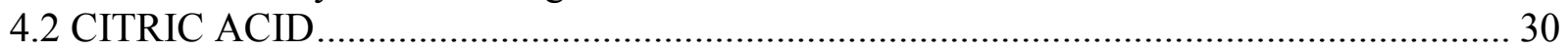

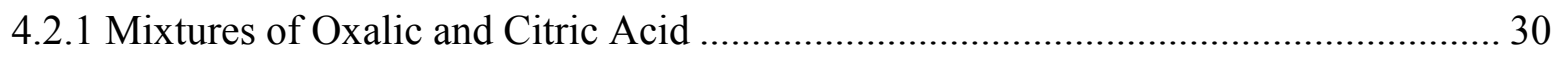

4.3 OXALIC ACID WITH HYDROGEN PEROXIDE ......................................................... 32

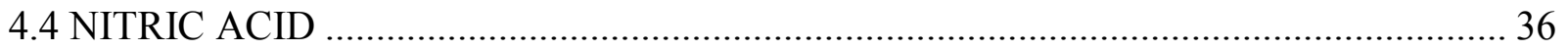

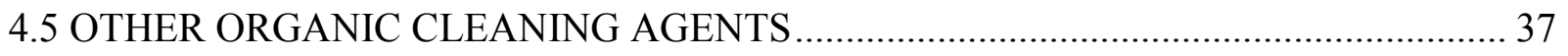

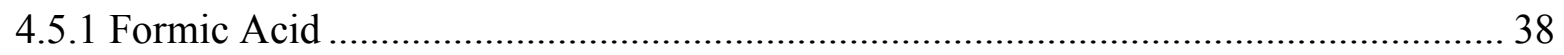

4.5.1.1 Formic Acid Experience with HLW Sludge in DWPF ........................................ 38

4.5.2 1-Hydroxyethane-1,1-Diphosphonic Acid........................................................... 40



5.0 SLUDGE COMPOUNDS AND PROCESS CHEMISTRY ............................................ 46

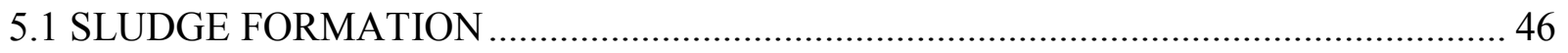

5.2 THE MECHANICAL STRENGTH OF AGGREGATES ……………............................ 47

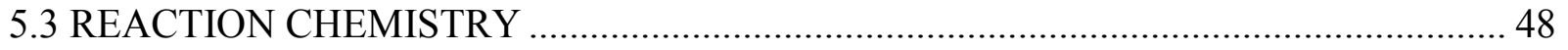

5.4 HEAT OF NEUTRALIZATION OF OXALIC ACID ………....................................... 50

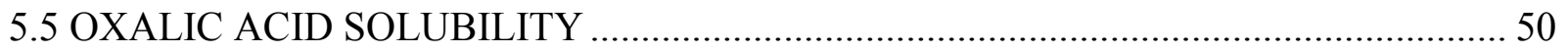

5.6 CLEANING AGENT EFFECTS ON SLUDGE COMPONENTS ………………............ 51

5.7 SOLUBILITY OF SLUDGE COMPONENTS IN OXALIC ACID .................................. 55

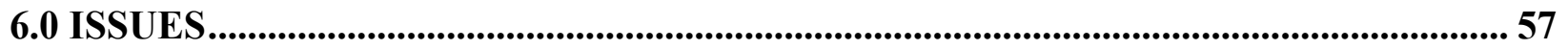

6.1 CORROSION OF CARBON STEEL IN CHEMICAL CLEANING SOLUTIONS ......... 57

6.1.1 Corrosion Mechanisms During Chemical Cleaning .................................................... 57 


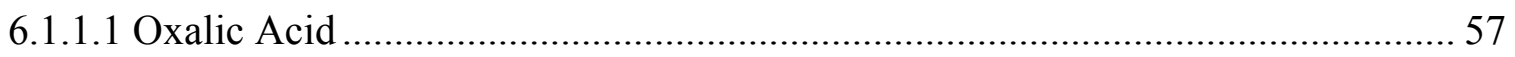

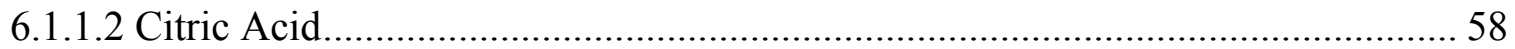



6.1.1.4 Oxalic Acid and Hydrogen Peroxide ................................................................. 58

6.1.1.5 Nitric Acid Corrosion Mechanism........................................................................ 58

6.1.1.6 Formic Acid Corrosion Mechanism.................................................................. 59

6.1.2 Review of Experimentally Determined Corrosion Rates............................................ 59



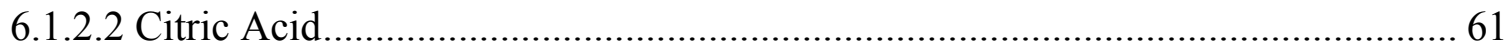

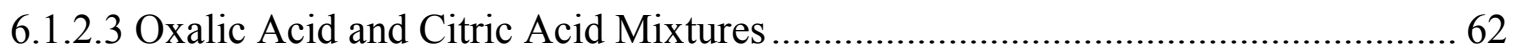

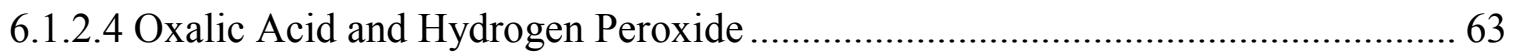

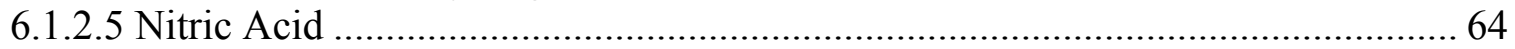

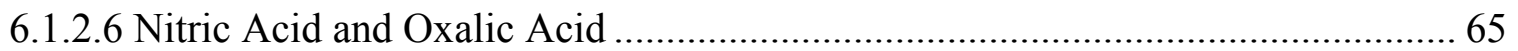

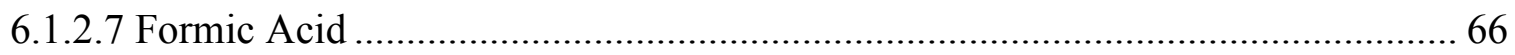

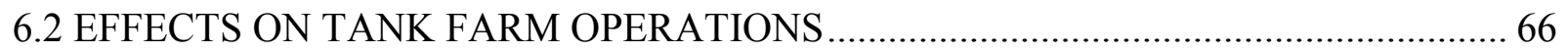

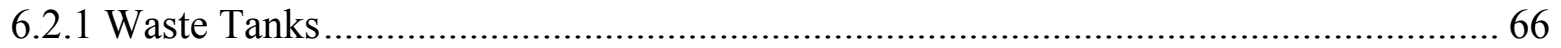

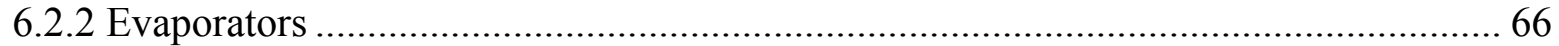

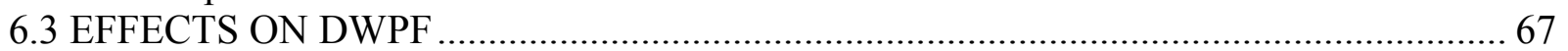

6.4 CRITICALITY AND MISCELLANEOUS SAFETY-RELATED INFORMATION N....... 69

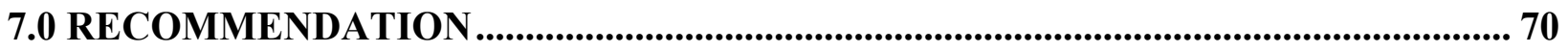

7.1 CLEANING AGENT RECOMMENDATION ………................................................ 70

7.2 HEEL REMOVAL CHEMICAL TREATMENT CONCEPTS ………............................ 71

7.3 GENERIC HEEL REMOVAL CHEMICAL TREATMENT PROCESS .......................... 71

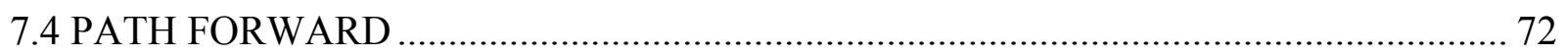

\section{LIST OF FIGURES}

Figure 1 Effect of Various Cleaning Agents on Dissolution of Sludge Species ......................... 20 Figure 2 Effect of Oxalic Acid Concentration, Temperature, and Contact Time on Dissolution of

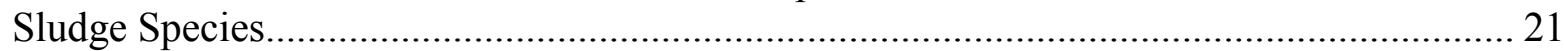

Figure 3 Effect of Oxalic Acid Concentration and Solution to Sludge Volume ratio on Simulated

Sludge Material (Contact time of 6 hours at $80^{\circ} \mathrm{C}$ )....................................................... 24

Figure 4 Sludge Components Dissolved as a Function of the Oxalic Acid to Sludge Volume



Figure 5 Dissolution of Sludge Components as a Function of Time............................................. 29

Figure 6 Appearance of Tank 16 Coil Sample as Received ........................................................ 33

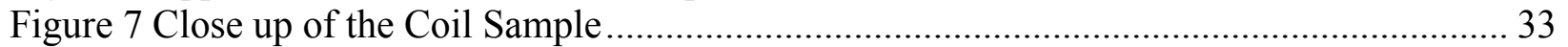

Figure 8 Appearance after Six Tests with 4 wt \% Oxalic Acid.................................................... 34

Figure 9 Appearance after Three Additional Treatments with $4 \mathrm{wt} \%$ Oxalic Acid containing 0.5

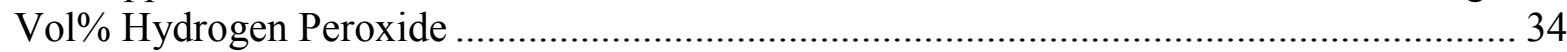

Figure 10 Close up of the Coil Sample after the Final Treatment with Oxalic Acid and Peroxide

Figure 11 Effect of Nitric Acid Concentration, Temperature, and Contact Time on Dissolution of

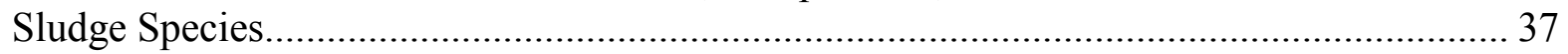

Figure 12 The Dissolution of Iron Oxide Compounds in $6 \mathrm{M} \mathrm{HCl}$......................................... 53

Figure 13 The Effect of the Complexing, Reducing and Acidic Agents on the Dissolution of

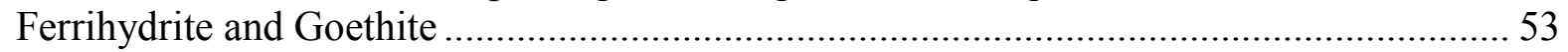




\section{LIST OF TABLES}





Table 3 Al/Fe Weight Ratio for Typical HM Waste Transfers …………………....................... 13

Table 4 Considerations for Heel Dissolution on F Area Type I Tanks ....................................... 14

Table 5 Considerations for Heel Dissolution on H Area Type I Tanks........................................ 14

Table 6 Considerations for Heel Dissolution on H Area Type II Tanks ...................................... 15

Table 7 Considerations for Heel Dissolution on F Area Type IV Tanks....................................... 16

Table 8 Considerations for Heel Dissolution on H Area Type IV Tanks ..................................... 16

Table 9 Composition of specific elements of interest in Simulated Tank 40H sludge.................. 19

Table 10 Composition of Specific Elements of Interest in Test Sludges ………………….......... 21

Table 11 Composition of Washed and Dried Tank 16H Sludge ............................................... 22

Table 12 Actual Tank 16H Waste Sludge (Raw and Dried Dissolution Data)............................. 25

Table 13 Test Conditions for Tank 16 Cleaning Demonstration................................................. 27

Table 14 Summary of Oxalic Acid Solution and Oxalic Acid-Hydrogen Peroxide Solution



Table 15 Composite Evaluation Matrix Scoring of the Various Cleaning Agents....................... 41

Table 16 Evaluation Matrix Scoring for Each Criterion.......................................................... 42

Table 17 Source of Salt and Sludge Components........................................................................ 46

Table 18 Amount of Oxalic Acid Needed to Leach Various Components Out of $1 \mathrm{~kg}$ of HM Sludge

Table 19 Amount of Oxalic Acid Needed to Leach Various Components Out of $1 \mathrm{~kg}$ of PUREX

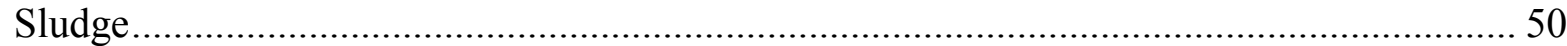

Table 20 Oxalic Acid Solubility in Water as a Function of Temperature ...................................5 51

Table 21 The Dissolution Rate of Common Sludge Compounds in Cleaning Solutions .............. 54

Table 22 Solubility of Various Sludge Components in Oxalic Acid........................................... 55

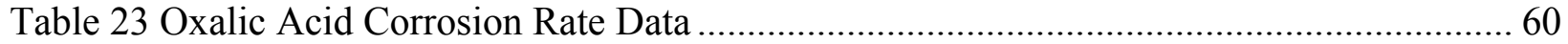

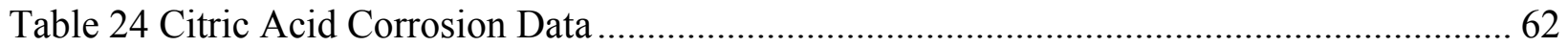

Table 25 Oxalic and Citric Acid Corrosion of Carbon Steel .......................................................... 63

Table 26 Corrosion Rate of Carbon Steel in Oxalic Acid-Hydrogen Peroxide as a Function of



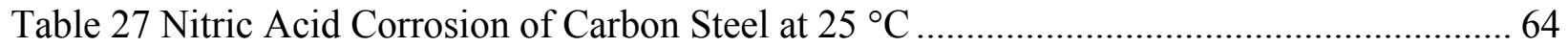

Table 28 Corrosion Rates for Carbon Steel in Mixtures of Nitric and Oxalic Acid...................... 65

Table 29 Corrosion Rates of Carbon Steel in Formic Acid (rates in inches per year) .................. 66 


\section{LIST OF ACRONYMS}

$\begin{array}{ll}\text { AB } & \text { Authorization Basis } \\ \text { DOE } & \text { Department of Energy } \\ \text { DSA } & \text { Documented Safety Analysis } \\ \text { DWPF } & \text { Defense Waste Processing Facility } \\ \text { EDTA } & \text { Ethylenediamine Tetra-acetic Acid } \\ \text { FS } & \text { Ferrous Sulfamate } \\ \text { HAW } & \text { High Activity Waste } \\ \text { HEDPA } & \text { Hydroxyethane-1, 1-diphosphonic Acid } \\ \text { HHW } & \text { High Heat Waste } \\ \text { HM } & \text { H-Modified } \\ \text { ICP-AES } & \text { Inductively Coupled Plasma Atomic Emission Spectroscopy } \\ \text { IH } & \text { Industrial Hygiene } \\ \text { LAW } & \text { Low Activity Waste } \\ \text { LHW } & \text { Low Heat Waste } \\ \text { LWD } & \text { Liquid Waste Disposition } \\ \text { MCC } & \text { Mining and Chemical Combine } \\ \text { MHW } & \text { Mixed Heat Waste } \\ \text { MST } & \text { Monosodium Titanate } \\ \text { PNNL } & \text { Pacific Northwest National Laboratory } \\ \text { PUREX } & \text { Plutonium Uranium Recovery and Extraction } \\ \text { REDOX } & \text { Reduction Oxidation } \\ \text { SME } & \text { Slurry Mix Evaporator } \\ \text { SPP } & \text { Salt Processing Program } \\ \text { SRAT } & \text { Sludge Receipt and Adjustment Tank } \\ \text { SRS } & \text { Savannah River Site } \\ \text { SRTC } & \text { Savannah River Technology Center } \\ \text { SS } & \text { Stainless Steel } \\ \text { TBP } & \text { Tributyl Phosphate } \\ \text { THOREX } & \text { Thorium Extraction Process } \\ \text { WAC } & \text { Waste Acceptance Criteria } \\ \text { WCP } & \text { Waste Caprolactam Product } \\ \text { WCS } & \text { Waste Characterization System } \\ \text { WSMS } & \text { Washington Safety Management Solutions } \\ & \end{array}$




\subsection{EXECUTIVE SUMMARY}

At the Savannah River Site (SRS) in Aiken, South Carolina, there are approximately 40 million gallons of legacy High Level Waste stored in large capacity sub-surface tanks. Twelve of these tanks are single-containment, non-conforming tanks with leaks. These tanks were built in the 1950s. Some of these tanks contain sludge heels and are being considered for near-term removal efforts and vitrification. Currently, only mechanical methods (i.e., pumps) are used to remove the sludge waste with varying degrees of success. To provide for additional levels of removal, chemically-aided techniques are being considered. This consideration is being driven by the need for tank closure. In response to this need, the Closure Business Unit requested the formation of a Waste Tank Heel Removal Chemical Cleaning Team to assess the current knowledge base.

The objective of the Waste Tank Heel Removal Chemical Cleaning Team was to collect and evaluate information available on chemical-based methods for removing residual solids from the Savannah River Site's waste tanks. As part of this study, the team was requested to develop recommendations for chemical treatments to remove residual heels (primarily sludge). Ideally, one agent alone would be efficient at dissolving all residual tank heels and yet satisfy all safety and process concerns. No such chemical cleaning agent was found. The cleaning agents that were identified from the literature, that would most likely find use at SRS, included oxalic acid, a mixture of oxalic acid and citric acid, a combination of oxalic acid with hydrogen peroxide, nitric acid, formic acid, and organics (considered as a whole - this group would include triethanolamine, 1-hydroxyethane-1,1-diphosphonic acid, EDTA, and many of the organic acids such as malonic and ascorbic acid). A criteria matrix for evaluating the various cleaning agents was developed.

The results of the evaluation conclusively support oxalic acid as the cleaning agent of choice for the immediate future. Oxalic acid scored nearly double the next closest cleaning agent. Nitric acid, formic acid, and oxalic acid with hydrogen peroxide were all closely grouped for the next best choice. The mixture of oxalic acid and citric acid rated poorly (mostly due to the fact that it performed less well than oxalic acid and the presence of citrate could adversely impact downstream operations such as the Salt Waste Processing Facility and the DWPF). Organics rated even more poorly due to large uncertainties in performance and downstream impacts.

The information summarized in this document indicates that differing sludge types (e.g., PUREX and HM) will exhibit varying dissolution characteristics. Furthermore, the environmental conditions that the sludge has been exposed to also affect their dissolution characteristics. For these reasons, the authors caution that expecting "one method fits all" is unfounded. Each tank (or at best groups of tanks with similar waste and similar historical conditioning) should be considered individually. Given that warning, oxalic acid offers the most generic application with the best chance of success.

Oxalic acid is the best choice for a number of reasons. First, oxalic acid has been widely studied and used several times to clean HLW tanks at SRS and at other sites within the DOE complex. Integration of oxalic acid into the Liquid Waste Disposition (LWD) system is likely the 
smoothest. Its effect on DWPF and the evaporators is better known. Oxalic acid has been shown to be effective for a wide variety of sludge types and out-performed nitric acid and other chemical cleaning agents in head to head tests. Because of its widespread use and familiarity in the DOE complex, oxalic acid should prove the easiest to pass regulatory, permitting, and perception concerns. Lastly, oxalic acid is less corrosive than nitric acid or a combination of oxalic acid and hydrogen peroxide.

The selection of a chemical cleaning method should be considered on an individual application basis. The use of low molarity nitric acid $(\sim 0.3 \mathrm{M})$ should be considered for use on specific spots or mounds of solids that remain unreactive to oxalic acid. Corrosion is less of an issue since the tanks are subject to closure. The use of hydrogen peroxide in combination with oxalic acid as a follow-up treatment to oxalic acid alone should be considered for increased surface decontamination of those tanks requiring lower residual radioactivity levels. The available data does not support the use of formic acid, citric acid (with or without oxalic acid), or any other agent at this time.

Oxalic acid offers the generic ability to work for most sludge types. Advanced sludge characterization and lab testing will help to minimize the volume of cleaning solution required while maximizing the degree of dissolution (and even defining the level of cleanliness required). The above recommendation to use oxalic acid should not be considered as a conclusion to this area of research. The authors recommend that a small task be maintained to annually evaluate new cleaning agents and provide additional information on existing cleaning agents including tests with tank sludges with the more promising cleaning agents. 


\subsection{INTRODUCTION}

The Savannah River Site (SRS) located near Aiken, SC was constructed in the 1950s to produce materials for national defense. As a result of its mission, SRS generated a large volume of high level radioactive waste. This waste has been stored in large capacity sub-surface waste tanks. Since construction, one tank has been emptied of waste, while two tanks have been closed and grouted. Currently, only 48 tanks are considered to contain HLW. Of these tanks, 24 were built in the 1950s -1960 s and provide only single containment and are the focus of this report. ${ }^{1}$ The wastes are being removed from the tanks and processed for eventual disposal in appropriate repositories.

Because of limitations on the availability of stainless steel during the construction of the earliest tanks (1950s), an alkaline process was required to minimize corrosion. The decided alkaline process ensured that all future tanks were also fabricated from carbon steel ${ }^{1}$.

Waste stored in these tanks are classified as supernate, salt (formed from evaporated supernate), or sludge. The later is the focus of this document. Sludge, a dark brown, sticky solid material forms from oxides and hydroxides of iron, aluminum, and manganese. The majority of this sludge is compacted into a solid mass which is somewhat difficult to remove from the tanks. The bulk of the waste sludge is removed using a hydraulic slurrying technique. The residual waste is termed the 'sludge heel' and is not easily removed by slurrying. To provide for additional levels of removal, chemically aided techniques are being considered. The focus of this study is the review of chemical treatments which can be used to dissolve the sludge heel. The studies reviewed in this document include a tremendous amount of useful information, but it is important to understand the limitations of each one. Studies performed with sludge simulants can be used to provide useful information but there are significant differences between real and simulated sludges. Applications to real waste provide the most relevant information but the data collected from these studies is limited by the radioactive nature of the sludge. There have been three full scale applications of sludge dissolution. All three used oxalic acid. Two of the three were performed at the Savannah River Site. The most notable and successful of these was oxalic acid cleaning of Tank $16 \mathrm{H}$ sludge in $1980 .^{2}$ Oxalic acid is currently being used for sludge dissolution in Hanford Tank C-106 (results currently unreported). The use of oxalic acid on the Tank $24 \mathrm{H}$ zeolite heel was not successful.

This document provides a review of the most relevant chemically aided attacks on sludge material as well as a review of the chemistry and properties associated with such an endeavor. 


\subsection{HIGH LEVEL WASTE DESCRIPTION}

Although many sources of potential data exist, the question, "What is in the tank?" is commonly answered by WCS. The Waste Characterization System (WCS) is a large, access controlled, living, process database developed and maintained across organizational lines within the Closure Business Unit at the Savannah River Site. Although a shared database, WCS is an official reference document which can provide the composition of the waste. ${ }^{3}$

\subsection{BULK CHARACTERIZATION}

As shown in Table 1, WCS breaks the bulk (macro characterization) contents down into very general categories, such as sludge volume and salt volume. The table shows the volumes for Tanks 1-24 as listed in WCS (on 9/2/03). ${ }^{3}$

Table 1 Bulk Properties and Constituents of the Tanks ${ }^{3}$

\begin{tabular}{|c|c|c|c|c|}
\hline Tank & $\begin{array}{c}\text { Sludge Volume } \\
\text { (gal) }\end{array}$ & $\begin{array}{c}\text { Salt } \\
\text { Volume (gal) }\end{array}$ & $\begin{array}{c}\text { Zeolite Volume } \\
\text { (gal) }\end{array}$ & $\begin{array}{c}\text { Grout Volume } \\
\text { (gal) }\end{array}$ \\
\hline 1 & 7000 & 480000 & 0 & 0 \\
\hline 2 & 4000 & 536000 & 0 & 0 \\
\hline 3 & 4000 & 536000 & 0 & 0 \\
\hline 4 & 127000 & 34000 & 0 & 0 \\
\hline 5 & 28000 & 0 & 0 & 0 \\
\hline 6 & 25000 & 0 & 0 & 0 \\
\hline 7 & 62000 & 0 & 0 & 0 \\
\hline 8 & 7000 & 0 & 0 & 0 \\
\hline 9 & 3000 & 538000 & 0 & 0 \\
\hline 10 & 3000 & 213000 & 0 & 0 \\
\hline 11 & 141000 & 0 & 0 & 0 \\
\hline 12 & 174000 & 92000 & 0 & 0 \\
\hline 13 & 223000 & 0 & 0 & 0 \\
\hline 14 & 27000 & 156000 & 0 & 0 \\
\hline 15 & 214000 & 102000 & 0 & 0 \\
\hline 16 & $1000 *$ & 0 & 0 & 0 \\
\hline 17 & $2000 *$ & 0 & 0 & 1300000 \\
\hline 18 & 110000 & 0 & 0 & 0 \\
\hline 19 & 3000 & 0 & 12000 & 0 \\
\hline 20 & $1000 *$ & 0 & 0 & 1300000 \\
\hline 21 & 14000 & 0 & 0 & 0 \\
\hline 22 & 21000 & 0 & 0 & 0 \\
\hline 23 & $43000^{*}$ & 0 & 0 & 0 \\
\hline 24 & $4000 *$ & 0 & 4000 & 0 \\
\hline
\end{tabular}

Note*: Tanks 17 and 20 are grouted, but are contained within this report in various stages to enable benchmarking. Additionally, resin in Tank 23 \& zeolite in Tank 24 may be indicated as sludge depending on application. Small contamination levels of sludge in tank 16 may be shown as 1000 gal depending on application.

In addition to the general categories, WCS also breaks down the sludge composition into approximately 40 chemical species and radionuclides. These bulk values are based on uniform mixing, and are commonly used to answer the question, "If mixed, what would the "bulk" sludge look like?" 3,4 
In some activities, even while using WCS, a more detailed knowledge of tank history and waste stream specific characterizations (micro characterization) may be required. Micro characterization would include identification of specific compounds in the sludge solids that control solubility in a particular acid solution. Note: although not found in the reference document, the term "macro" and "micro" are used herein for clarification.

\subsection{WASTE STREAM-SPECIFIC CHARACTERIZATION}

The sludge additions to the tanks are based on three major processing campaigns, ${ }^{4,5,6} \mathrm{~F}-\mathrm{Canyon}$ PUREX, H-Canyon PUREX, and H-Canyon Modified (HM). The wastes contributions are further accounted for by the (Separations) process content and header through which the waste is transferred to the tank farm. The waste transferred through the High Heat Waste Header (HHW) generally contains centrifuge cakes from the head end and waste from first cycle. The waste transferred through the Low Heat Waste header (LHW) generally contains waste from second uranium cycle, second product cycle, solvent washes, equipment decontamination, and other low fission product sources. Mixed Heat Waste, is a mixture of HHW and LHW that is transferred through the HHW header.

(Note: A detailed discussion of waste streams is beyond the scope of this report. For a detailed understanding, please consult References 4, 5, and 6.)

\subsubsection{PUREX Waste}

The PUREX process recovers uranium and plutonium from irradiated depleted uranium targets. The targets are hollow slugs of uranium metal clad in a thin coating of aluminum. Before dissolving the uranium, the aluminum cladding is removed with sodium hydroxide and sodium nitrate. Then the uranium metal, plutonium, and fission products are dissolved in nitric acid. ${ }^{6}$

Uranium and plutonium are separated from each other and decontaminated from fission products by a solvent extraction process using tributyl phosphate as an extractant. Nitric acid is used to salt or promote extraction of the uranium and plutonium by the solvent, and the ferrous sulfamate (FS) reductant is used to adjust the valence of the plutonium. ${ }^{6}$

Prior to receipt in the tank farm, the waste was normally evaporated for concentration and nitric acid recovery and neutralized with $\mathrm{NaOH}$. In the canyon, the amount of waste sent to the tank farm from PUREX is expressed in gallons per metric ton of uranium (MTU). ${ }^{6}$

In all PUREX campaigns, the sum of iron and aluminum waste represents in excess of $60 \%$ of the total solids mass. The calculated Al/Fe ratios for the HHW, MHW, and LHW PUREX streams (often assumed to be a potentially good indicator of oxalic acid dissolution effectiveness based on particle size, rheology, and behavior of known sludge simulate dissolution behavior) is shown in Table 2.

\subsubsection{HM}

Since June 1959, the HM process has been used in H-Canyon to recover unused uranium and byproduct neptunium from spent enriched uranium reactor fuel, with $\mathrm{Np}$ recovery starting in November 1960. The process is similar to the PUREX process. The fuel is typically in the form 
Table 2 Al/Fe Weight Ratio for PUREX Waste Transfers ${ }^{6}$

\begin{tabular}{|c|c|c|c|}
\hline Year & HHW & LHW & MHW \\
\hline 1955 & 0.08 & 0.59 & 0.69 \\
\hline 1956 & 0.10 & 0.88 & 0.90 \\
\hline 1957 & 0.08 & 3.25 & 1.27 \\
\hline 1958 & 0.10 & 3.42 & 1.45 \\
\hline 1959 & 0.10 & 3.25 & 1.44 \\
\hline 1960 & 0.02 & 3.25 & 0.30 \\
\hline 1961 & 0.03 & 3.38 & 0.56 \\
\hline 1962 & 0.03 & 3.47 & 0.43 \\
\hline 1963 & 0.05 & 6.64 & 0.43 \\
\hline 1964 & 0.03 & 1.75 & 0.25 \\
\hline 1965 & 0.07 & 1.93 & 0.49 \\
\hline 1966 & 0.05 & 6.47 & 0.45 \\
\hline 1967 & 0.05 & 6.47 & 0.45 \\
\hline 1968 & 0.02 & 3.23 & 0.20 \\
\hline 1969 & 0.03 & 1.61 & 0.22 \\
\hline 1970 & 0.03 & 1.61 & 0.22 \\
\hline 1971 & 0.02 & 1.61 & 0.20 \\
\hline 1971 to most current & 0.02 & 1.61 & 0.20 \\
\hline
\end{tabular}

of long tubes of uranium and aluminum alloy, clad in aluminum. The uranium alloy fuel tubes and the cladding were dissolved in nitric acid using a mercury catalyst to dissolve the aluminum. ${ }^{7}$

The head end decontamination step uses a manganese dioxide precipitate formed from manganese nitrate to absorb the fission product zirconium and niobium from the dissolved fuel. Uranium and neptunium are separated from each other and decontaminated from fission products by solvent extraction using $7.5 \%$ TBP as the extractant. ${ }^{6}$

Aluminum nitrate from the dissolved fuel and nitric acid are used to salt the uranium and neptunium into the solvent, and ferrous sulfamate is used to adjust the valence of the neptunium. The waste from the HM process is evaporated for concentration and nitric acid recovery, neutralized with sodium hydroxide, and transferred to the tank farm. In the canyon, the amount of waste sent to the tank farm from HM is normally expressed in terms of aluminum. ${ }^{6}$

Feed to the HM process has included a variety of offsite materials in addition to material from the SRS reactors. Special campaigns have also been carried out in the H-Canyon. For both iron and aluminum, the process efficiencies varied. THOREX and Frames process, as well as the special stainless steel clad campaigns are often included in the HM process. ${ }^{6}$

The THOREX process was conducted on April through May 1964, and January through February 1965. During this time ${ }^{233} \mathrm{U}$ was recovered and all Th was discarded through HHW. From 1965 to 1969 the THOREX process was run to recover both ${ }^{233} \mathrm{U}$ and Th. During this time, therefore, Th waste was transferred to both the HHW and LHW. (Note: FS is not used in the 
THOREX process) For the THOREX campaigns, separation process efficiencies are scaled to Th. For other waste streams, such as the Stainless Steel (SS) clad rods, separation process efficiencies are scaled to SS. ${ }^{6}$

The Frames process operated in H-Canyon between 1961 and May 1986 to recover ${ }^{237} \mathrm{~Np}$ and ${ }^{238} \mathrm{Pu}$ from irradiated $\mathrm{NpO}_{2}-\mathrm{Al}$ tubes. The $\mathrm{Np}$ which was not recovered was discarded to LHW through the Frame Recovery System. ${ }^{6}$

Because of the variability in the types of $\mathrm{HM}$ streams, the $\mathrm{Al} / \mathrm{Fe}$ ratios are based on the different ratios of Tanks 11-16 and Tank 21. ${ }^{5}$ The calculated Al/Fe ratios for the HHW, and LHW HM (often assumed to be a potentially good indicator of oxalic acid dissolution effectiveness based on particle size, rheology, and behavior of known sludge simulate dissolution behavior) are shown in Table 3.

Table 3 Al/Fe Weight Ratio for Typical HM Waste Transfers ${ }^{5}$

\begin{tabular}{|c|c|c|}
\hline Waste & $\begin{array}{c}\text { Bounding } \\
\text { Process Ratio }\end{array}$ & Notes \\
\hline HM HHW & 3.359 & Almost all 3.315 a few as low as .00277 \\
\hline HM LHW & 0.969 & significant variability \\
\hline $\begin{array}{c}\text { THOREX } \\
\text { HHW }\end{array}$ & Not Applicable & FS is not used in the THOREX process \\
\hline $\begin{array}{c}\text { THOREX } \\
\text { LHW }\end{array}$ & Not Applicable & FS is not used in the THOREX process \\
\hline
\end{tabular}

\subsection{TANK CONSIDERATIONS FOR HEEL REMOVAL}

Various factors may affect the amount of heel allowed to remain in a tank during tank closure, as well as the potential effectiveness of heel removal efforts. The following information is included to provide an overview of some of the variation, amongst tanks, and hence suggest some level of potential difficulty.

The actual level of difficulty or probability of success however, must include many factors, not limited to an assessment of the available equipment and impact during heel removal (e.g. available pumps).

\subsubsection{Type I Tanks}

Type I Tanks were constructed as the original waste processing tanks during 1952 and 1953. The tanks have a diameter of 75 feet and a height of $241 / 2 \mathrm{ft}$, with a design capacity of 750,000 gallons. The shell and $5 \mathrm{ft}$ annulus pan is constructed of $1 / 2$ inch thick carbon steel. Internally, these tanks have twelve 2 foot wide columns that may make heel removal difficult. $8,9,10,11,14,15$ Tanks 1-8 are F-Area, Type I tanks. Tanks 1-8 contain mostly separation process fresh waste that is the sludge is attributed to PUREX waste. 5,6 Tanks 9-12 are Type I tanks in H Area and received both HM and PUREX wastes. ${ }^{5,6}$ Refer to Table 4 and Table 5. 
Table 4 Considerations for Heel Dissolution on F Area Type I Tanks

\begin{tabular}{|c|c|c|c|c|c|c|}
\hline है & $\begin{array}{c}\text { Receipt } \\
\text { Variation } \\
\text { \& Inter- } \\
\text { Tank }^{5}\end{array}$ & $\begin{array}{c}\text { Initial } \\
\text { Sludge } \\
\text { Type/Yr }{ }^{6}\end{array}$ & $\begin{array}{c}\text { Sludge } \\
\text { Removal } \\
\text { Year/ } \\
\text { Sludge } \\
\text { Remaining } \\
\text { (gal) } \\
\end{array}$ & $\begin{array}{c}\text { Max } \\
\text { Sludge } \\
\text { Temp } \\
\text { From } \\
\text { History } \\
\left({ }^{\circ} \mathrm{C}\right) \\
\end{array}$ & $\begin{array}{c}\text { Lowest Leak } \\
\text { Elevation } \\
\text { Annulus Waste (gal) }{ }^{12}\end{array}$ & $\begin{array}{l}\text { Other Misc } \\
\text { Transfers }^{13}\end{array}$ \\
\hline 1 & $\frac{\text { PUREX }}{\text { HHW* }}$ & $\begin{array}{l}\text { PUREX } \\
\text { HHW } \\
1954\end{array}$ & $\begin{array}{l}1969^{8} \\
7000 \text { gallons }\end{array}$ & $344^{8}$ & $\begin{array}{l}\text { Location unknown } \\
\text { "SMALL DEPOSITS ON } \\
\text { FLOOR" }\end{array}$ & $\begin{array}{l}\text { From } 1969-731 \text { received } \\
\text { evap conc }\end{array}$ \\
\hline 2 & $\frac{\text { PUREX }}{\text { HHW }^{*}}$ & $\begin{array}{l}\text { PUREX } \\
\text { HHW } \\
1955\end{array}$ & $\begin{array}{l}1966^{9} \\
4000 \text { gallons }\end{array}$ & $85^{9}$ & $\begin{array}{l}\text { NA } \\
\text { NA }\end{array}$ & $\begin{array}{l}\text { From } 1967-73 \text { received } \\
\text { evap conc }\end{array}$ \\
\hline 3 & $\begin{array}{l}\text { PUREX } \\
\text { HHW* }\end{array}$ & $\begin{array}{l}\text { PUREX } \\
\text { HHW } \\
1956\end{array}$ & $\begin{array}{l}1968^{10} \\
4000 \text { gallons }\end{array}$ & $110^{10}$ & $\begin{array}{l}\text { NA } \\
\text { NA }\end{array}$ & $\begin{array}{l}\text { From } 1968-73 \text { received } \\
\text { evap conc }\end{array}$ \\
\hline 4 & $\frac{\text { PUREX }}{\text { HHW }}$ & $\begin{array}{l}\text { PUREX } \\
\text { HHW } \\
1961\end{array}$ & $\begin{array}{l}\mathrm{NA}^{11} \\
127000 \text { gallons }\end{array}$ & $120^{11}$ & $\begin{array}{l}\text { NA } \\
\text { NA }\end{array}$ & $\begin{array}{l}\text { From } 1970-73 \text { received } \\
\text { evap conc }\end{array}$ \\
\hline 5 & $\frac{\text { PUREX }}{\text { HHW* }}$ & $\begin{array}{l}\text { PUREX } \\
\text { HHW } \\
1959 \\
\end{array}$ & $\begin{array}{l}\mathrm{NA}^{14} \\
28000 \text { gallons }\end{array}$ & $125^{14}$ & $\begin{array}{l}\text { Two at } 31 \text { " rest above } 45 " \\
\text { Around } 1 \text { gallon @ } 10 \text { of the } \\
15 \text { sites }\end{array}$ & $\begin{array}{l}\text { Received High } \\
\text { Chlorides SRTC } \\
\text { Curium Transfers }\end{array}$ \\
\hline 6 & $\frac{\text { PUREX }}{\text { HHW }}$ & $\begin{array}{l}\text { PUREX } \\
\text { HHW } \\
1964\end{array}$ & $\begin{array}{l}\mathrm{NA}^{15} \\
25000 \text { gallons }\end{array}$ & $100^{15}$ & $\begin{array}{l}\text { Lowest at } 129 " \sim 92 \text { gallons } \\
\text { liquid during original leakage. } \\
\leq 1 \text { inch dried waste }\end{array}$ & Received SRL transfers \\
\hline 7 & $\begin{array}{l}\text { PUREX } \\
\text { HHW } \\
\text { LHW }\end{array}$ & $\begin{array}{l}\text { PUREX } \\
\text { LHW } \\
1954 \\
\end{array}$ & $\begin{array}{l}2003 \\
62000 \mathrm{gal}\end{array}$ & $\begin{array}{l}120 \\
\text { Est. }\end{array}$ & $\begin{array}{l}\text { NA } \\
\text { NA }\end{array}$ & $\begin{array}{l}\text { Received Reactor Heat } \\
\text { exchanger flushes }\end{array}$ \\
\hline 8 & $\begin{array}{l}\text { PUREX } \\
\text { HHW } \\
\text { LHW }\end{array}$ & $\begin{array}{l}\text { PUREX } \\
\text { LHW } \\
1956 \\
\end{array}$ & $\begin{array}{l}2000 \\
6500 \mathrm{gal} \\
\end{array}$ & $\begin{array}{l}120 \\
\text { Est. }\end{array}$ & $\begin{array}{l}\text { NA } \\
\text { NA }\end{array}$ & $\begin{array}{l}\text { Received High } \\
\text { Chlorides SRTC } \\
\text { Curium Transfers }\end{array}$ \\
\hline
\end{tabular}

*Note: Early PUREX HHW contained LAW, and depending on effort may be best represented by MHW.

Table 5 Considerations for Heel Dissolution on H Area Type I Tanks

\begin{tabular}{|c|c|c|c|c|c|c|}
\hline 芫 & $\begin{array}{l}\text { Receipt } \\
\text { Variation } \\
\text { \& Inter- } \\
\text { Tank }^{5}\end{array}$ & $\begin{array}{c}\text { Initial } \\
\text { Sludge } \\
\text { Type/Yr } \\
6\end{array}$ & $\begin{array}{c}\text { Sludge } \\
\text { Removal } \\
\text { Year/ } \\
\text { Sludge } \\
\text { Remaining } \\
\text { (gal) }\end{array}$ & $\begin{array}{c}\text { Max } \\
\text { Sludge Temp } \\
\text { From History } \\
\left({ }^{\circ} \mathrm{C}\right)\end{array}$ & $\begin{array}{c}\text { Lowest Leak } \\
\text { Elevation } \\
\text { Annulus Waste (gal) }{ }^{12}\end{array}$ & $\begin{array}{l}\text { Other Misc } \\
\text { Transfers }^{13}\end{array}$ \\
\hline 9 & $\begin{array}{l}\text { PUREX } \\
\text { HHW } \\
\text { LHW }\end{array}$ & $\begin{array}{l}\text { PUREX } \\
\text { HHW } \\
1955\end{array}$ & $\begin{array}{l}1966^{16} \\
3000 \text { gallons }\end{array}$ & $\begin{array}{l}80 ; \\
\text { most } 50^{16}\end{array}$ & $\begin{array}{l}\text { Unknown (source of waste in } \\
\text { pan unknown) } \\
10-12 \text { inches of waste. } \\
\text { Annulus previously cleaned } \\
\text { March 1958-Feb } 1959\end{array}$ & NA \\
\hline $\begin{array}{l}1 \\
0\end{array}$ & $\frac{\text { PUREX }}{\text { HHW }}$ & $\begin{array}{l}\text { PUREX } \\
\text { HHW } 1956\end{array}$ & $\begin{array}{l}1968^{17} \\
3000 \text { gallons }\end{array}$ & $\begin{array}{l}40 \text { (but supernate } \\
\text { at } 100)^{17}\end{array}$ & $\begin{array}{l}\text { Unknown } \\
\text { 2-3 inches covering floor }\end{array}$ & $\begin{array}{l}\text { From 1968-73 received } \\
\text { evap conc }\end{array}$ \\
\hline \begin{tabular}{|l|}
1 \\
1
\end{tabular} & $\begin{array}{l}\text { PUREX } \\
\text { LHW } \\
\text { HM } \\
\text { HHW } \\
\text { THOREX } \\
\text { LHW }\end{array}$ & $\begin{array}{l}\text { PUREX } \\
\text { LHW } \\
1955\end{array}$ & $\begin{array}{l}1969^{18} \\
140000 \text { (note: } \\
\text { removal with } \\
\text { limited } \\
\text { success) }\end{array}$ & $100^{18}$ & $\begin{array}{l}189 \text { “ } \\
\text { Nodules/waste on wall and } \\
\text { trace amounts on annulus pan } \\
\text { due to solids washing down } \\
\text { wall }\end{array}$ & NA \\
\hline \begin{tabular}{|l|}
1 \\
2
\end{tabular} & $\begin{array}{l}\text { PUREX } \\
\text { HHW } \\
\text { HM } \\
\text { HHW } \\
\text { THOREX }\end{array}$ & $\begin{array}{l}\text { PUREX } \\
\text { HHW } 1956\end{array}$ & $\begin{array}{l}\text { NA }^{19} \\
174000 \\
\text { (Note: No } \\
\text { previous } \\
\text { sludge } \\
\text { removal) } \\
\end{array}$ & $138^{19}$ & $\begin{array}{l}93 \text { “ } \\
\text { Nodules/waste on wall and } \\
\text { trace amounts on annulus pan } \\
\text { due to solids washing down } \\
\text { wall }\end{array}$ & $\begin{array}{l}\text { A transfer to Tank } 21 \\
\text { was stopped because } \\
\text { sludge was being } \\
\text { transferred (1969) }\end{array}$ \\
\hline
\end{tabular}

*Note: Early PUREX HHW contained LAW, and depending on effort may be best represented by MHW. 


\subsubsection{Type II Tanks}

Tanks 13-16 are Type II tanks in H-Area. Half of the tanks received some PUREX waste, while all received some HM waste. The Type II tanks were constructed in 1955 and 1956. The tanks have a 85 feet diameter, a height of $27 \mathrm{ft}$, with the design capacity of 1,030,000 gallons. The top, bottom, and annulus pan are made of $1 / 2$ inch thick carbon steel. There are also slightly thicker upper and lower knuckle plates. The roof support is one central concrete column clad with carbon steel. ${ }^{20,21,22}$ Refer to Table 6 .

Table 6 Considerations for Heel Dissolution on H Area Type II Tanks

\begin{tabular}{|c|c|c|c|c|c|c|}
\hline 吾 & $\begin{array}{c}\text { Receipt } \\
\text { Variation } \\
\text { \& Inter- } \\
\text { Tank }^{5}\end{array}$ & $\begin{array}{c}\text { Initial } \\
\text { Sludge } \\
\text { Type/Yr }\end{array}$ & $\begin{array}{c}\text { Sludge } \\
\text { Removal } \\
\text { Year/ } \\
\text { Sludge } \\
\text { Remaining } \\
\text { (gal) }\end{array}$ & $\begin{array}{c}\text { Max } \\
\text { Sludge } \\
\text { Temp } \\
\text { From } \\
\text { History } \\
\left({ }^{\circ} \mathrm{C}\right)\end{array}$ & $\begin{array}{c}\text { Lowest Leak } \\
\text { Elevation } \\
\begin{array}{c}\text { Annulus Waste } \\
\text { (gal) }\end{array}\end{array}$ & $\begin{array}{l}\text { Other Misc } \\
\text { Transfers }^{13}\end{array}$ \\
\hline $\begin{array}{l}1 \\
3\end{array}$ & $\begin{array}{l}\text { PUREX } \\
\text { HHW } \\
\text { LHW } \\
\text { HM } \\
\text { HHW } \\
\text { LHW } \\
\text { THOREX }\end{array}$ & $\begin{array}{l}\text { PUREX } \\
\text { LHW } \\
1956\end{array}$ & $\begin{array}{l}\mathrm{NA}^{20} \\
223000 \text { gallons } \\
\text { (received tank } 9 \text { in } \\
66, \text { tank } 10 \text { in } \\
1968, \text { tank } 14 \text { in } \\
68, \text { tank } 11 \text { in } \\
1969^{5}\end{array}$ & $\begin{array}{l}50 \text { (but } \\
\text { supernate at } \\
80)^{20}\end{array}$ & $\begin{array}{l}269 " \\
\text { nodules/waste on } \\
\text { wall and trace } \\
\text { amounts on annulus } \\
\text { pan due to solids } \\
\text { washing down wall }\end{array}$ & $\begin{array}{l}\text { Evap Feed Tank - } \\
\text { 1988, } \\
\text { 1976 Received } 605 \\
\text { lbs of free nitric }\end{array}$ \\
\hline $\begin{array}{l}1 \\
4\end{array}$ & $\begin{array}{l}\text { PUREX } \\
\text { HHW } \\
\text { HM } \\
\text { HHW } \\
\text { LHW } \\
\text { THOREX } \\
\end{array}$ & $\begin{array}{l}\text { PUREX } \\
\text { HHW } \\
1957\end{array}$ & $\begin{array}{l}1968^{21} \\
27000 \text { gallons }^{5}\end{array}$ & $125^{21}$ & $\begin{array}{l}16 " \\
12-13 \text { inches in } \\
\text { annulus }\end{array}$ & $\begin{array}{l}\text { Received Tank } 16 \\
\text { annulus waste }\end{array}$ \\
\hline $\begin{array}{l}1 \\
5\end{array}$ & $\begin{array}{l}\text { HM } \\
\text { HHW } \\
\text { LHW } \\
\text { THOREX }\end{array}$ & $\begin{array}{l}\text { HM HHW } \\
1960\end{array}$ & $\begin{array}{l}1969 \& 1982^{5} \\
214000 \mathrm{gal}\end{array}$ & $125^{5}$ (Est.) & $\begin{array}{l}5 @ 30 \text { " } \\
\text { Nodules/waste on } \\
\text { wall and trace } \\
\text { amounts on annulus } \\
\text { pan due to solids } \\
\text { washing down wall }\end{array}$ & $\begin{array}{l}\text { NA } \\
\text { (Waste Removal } \\
\text { performed and tank } \\
\text { was used again for } \\
\text { Fresh LHW } \\
\text { Receipts) }\end{array}$ \\
\hline $\begin{array}{l}1 \\
6\end{array}$ & $\begin{array}{l}\text { HM } \\
\text { HHW } \\
\text { LHW } \\
\text { THOREX }\end{array}$ & $\begin{array}{l}\text { HM HHW } \\
1960\end{array}$ & $\begin{array}{l}1978^{2} \\
\text { WCS may show as } \\
1000 \text { gal } \\
\text { depending on } \\
\text { application } \\
\text { clean }(<1 \text { inch } \\
\text { remaining) }\end{array}$ & $125^{22}$ & $\begin{array}{l}\text { Tank is empty } \\
\text { But has various leak } \\
\text { sites } \\
\text { 2-10" inches of } \\
\text { material remains in } \\
\text { the annulus }\end{array}$ & NA \\
\hline
\end{tabular}

\subsubsection{Type IV Tanks}

Type IV Tanks are addressed in this report for informational purposes only. It is not anticipated that chemical cleaning of the tanks will be required to meet closure criteria.

Tanks 17-20 are Type IV Tanks in F-Area. Two of these tanks have been grouted and closed, while closure activities have begun on the remaining two. These tanks were designed to only receive PUREX LHW. Although process records do not record fresh waste receipts into Tank 20, some PUREX sludge, attributed to carry-over was found during closure. ${ }^{5,6,23,24}$ Table 7 provides a summary of Type IV tanks in F-Area. 
Table 7 Considerations for Heel Dissolution on F Area Type IV Tanks

\begin{tabular}{|c|c|c|c|c|c|}
\hline Е & $\begin{array}{l}\text { Receipt } \\
\text { Variation } \\
\text { \& Inter- } \\
\text { Tank }^{5}\end{array}$ & $\begin{array}{c}\text { Initial } \\
\text { Sludge } \\
\text { Type/Yr }{ }^{6}\end{array}$ & $\begin{array}{c}\text { Sludge Removal } \\
\text { Year/ } \\
\text { Sludge Remaining } \\
\text { (gal) }\end{array}$ & $\begin{array}{c}\text { Max } \\
\text { Sludge Temp } \\
\text { From History } \\
\left({ }^{\circ} \mathrm{C}\right)\end{array}$ & $\begin{array}{c}\text { Other Miscellaneous } \\
\text { Transfers }^{13}\end{array}$ \\
\hline 17 & $\frac{\text { PUREX }}{\text { LHW }}$ & $\begin{array}{l}\text { PUREX LHW } \\
1961\end{array}$ & $\begin{array}{l}1984^{23} \\
\text { WCS may show as } 2000 \\
\text { gal, since closed delisted } \\
\text { and may show as } 0 \text { gal. } \\
\text { (Mostly Transferred to } \\
\text { Tank 18) }\end{array}$ & $80^{23}$ & $\begin{array}{l}\text { Tank closed } \\
\text { Received mostly SRTC trailer } \\
\text { waste from 1974-1981 and } \\
\text { evap conc from 1964-1966 }\end{array}$ \\
\hline 18 & $\frac{\text { PUREX }}{\text { LHW }}$ & $\begin{array}{l}\text { PUREX LHW } \\
1959\end{array}$ & $\begin{array}{l}1986-1987 \& 2002 \\
\text { The } 1986-87 \text { sludge was } \\
\text { transferred to Tank } 40,42, \\
\& 51^{3} \\
\text { Currently undergoing } \\
\text { waste removal efforts } \\
\text { WCS shows as } 141,000 \\
\text { gal }^{3}\end{array}$ & 80 (Est.) & $\begin{array}{l}\text { Received various transfers } \\
\text { from } 17,19, \& 20\end{array}$ \\
\hline 19 & $\begin{array}{l}\text { PUREX } \\
\text { LHW }\end{array}$ & $\begin{array}{l}\text { PUREX LHW } \\
1974\end{array}$ & $\begin{array}{l}1999^{3} \\
3000 \text { gal with } 12000 \text { gal of } \\
\text { zeolite; } \\
\text { Currently undergoing } \\
\text { closure efforts }\end{array}$ & $80^{24}$ & $\begin{array}{l}\text { Received evap conc from } \\
1962 \text { to } 1976\end{array}$ \\
\hline 20 & $\frac{\text { PUREX }}{\text { HHW }}$ & $\begin{array}{l}\text { NA; Carryover } \\
\text { from evap }\end{array}$ & $\begin{array}{l}1988^{3} \\
\text { WCS may show as } 1000 \\
\text { gal, since closed delisted } \\
\text { and may show as } 0 \text { gal. }\end{array}$ & 80 , normally $60^{25}$ & $\begin{array}{l}\text { Tank Closed } \\
\text { Received evap conc from } \\
1960 \text { to } 1971\end{array}$ \\
\hline
\end{tabular}

Table 8 Considerations for Heel Dissolution on H Area Type IV Tanks

\begin{tabular}{|c|c|c|c|c|c|}
\hline  & $\begin{array}{l}\text { Receipt } \\
\text { Variation } \\
\text { \& Inter- } \\
\text { Tank }^{5}\end{array}$ & $\begin{array}{c}\text { Initial } \\
\text { Sludge } \\
\text { Type/Yr }{ }^{6}\end{array}$ & $\begin{array}{c}\text { Sludge } \\
\text { Removal } \\
\text { Year/ } \\
\text { Sludge } \\
\text { Remaining } \\
\text { (gal) } \\
\end{array}$ & $\begin{array}{c}\text { Max } \\
\text { Sludge Temp } \\
\text { From History } \\
\left({ }^{\circ} \mathrm{C}\right)\end{array}$ & $\begin{array}{c}\text { Other Miscellaneous } \\
\text { Transfers }^{13}\end{array}$ \\
\hline 21 & $\frac{\mathrm{HM}}{\mathrm{LHW}}$ & $\begin{array}{l}\text { HM LHW } \\
1976\end{array}$ & $\begin{array}{l}1986 \text { (as part of } \\
\text { sludge feed for } \\
\text { DWPF)Receipts } \\
\text { from Tank } 16 \\
\text { (79) and } 22(86) \\
14000 \text { gallons }{ }^{3,26}\end{array}$ & $85^{26}$ & $\begin{array}{l}\text { Received RBOF/RRF 1963-1992, } \\
\text { From 1961-74 received evap feed, } \\
\text { Received unknown quantity of } \\
\text { Tank } 14 \text { sludge (1969), } \\
\text { Transfer from } 12 \text { was stopped } \\
\text { because contained sludge (1969) }\end{array}$ \\
\hline 22 & $\begin{array}{l}\text { HM } \\
\text { LHW } \\
\text { THOREX } \\
\text { LHW }\end{array}$ & $\begin{array}{l}\text { HM LHW } \\
1974\end{array}$ & $\begin{array}{l}1986 \text { (as part of } \\
\text { sludge feed for } \\
\text { DWPF); } \\
21000 \text { gallons }^{27}\end{array}$ & $85^{27}$ & $\begin{array}{l}1966 \text { received evap concentrate, } \\
\text { Received some RBOF/RRF waste } \\
\text { mostly from Tank } 23 \text {, } \\
\text { 1997-current DWPF recycle } \\
\text { receipt tank }\end{array}$ \\
\hline 23 & $\begin{array}{l}\text { RBOF/RRF } \\
\text { Receipt Tank }\end{array}$ & NA & $\begin{array}{l}\text { NA } \\
\text { WCS may show as } \\
43000 \text { gal, most } \\
\operatorname{resin}^{28}\end{array}$ & $70^{28}$ & $\begin{array}{l}\text { Mostly overspec, evap. } \\
\text { Overheads and other non canyon } \\
\text { waste } \\
\text { May contain ion exchange resin }\end{array}$ \\
\hline 24 & $\begin{array}{l}\text { Evaporator } \\
\text { Concentrate }\end{array}$ & NA & $\begin{array}{l}\text { NA } \\
\text { WCS may show as } \\
4000 \text { gal, most } \\
\text { carryover, but } \\
\text { contains zeolite }^{29}\end{array}$ & $100^{29}$ & $\begin{array}{l}\text { CRC flushes, evap concentrate, } \\
\text { and CRC flushes. } \\
\text { Contains spent zeolite. } \\
\text { Based on potential sludge } \\
\text { carryover through the evaporator } \\
\text { sludge may be present. }\end{array}$ \\
\hline
\end{tabular}


Tanks 21-24 are Type IV tanks in H Area. Out of Tanks 21-24, only Tanks 21 and 22 have been recorded as receiving fresh sludge-containing waste. In both cases it was HM type sludge wastes. Tank 21 received 99\% LHW and 1\% HHW, while Tank 22 received only LHW. Tanks 23 and 24 have not been recorded as receiving fresh canyon process waste, although some sludge carry-over may have occurred from supernate transfers. ${ }^{5,6,26,27,28,29}$ Table 8 provides a summary of Type IV tanks in H-Area.

The Type IV tanks were constructed between 1958 and 1963. The tank has a design capacity of $1,300,000$ gallons. The top is made of a concrete domed roof. The shell and bottom are made from $3 / 8$ inch carbon steel, with a lower knuckle plate of 7/16 inch. There is no steel annulus since concrete surrounds the primary shell. ${ }^{23,24,25,26,27,28,29}$ 


\subsection{CHEMICAL CLEANING AGENTS}

There has been a significant amount of work performed on the chemical dissolution of high level waste sludges. This work has been performed primarily at the Savannah Rive Site but there has also been work performed at the Hanford site in Washington state and by a Russian team. This work spans over three decades and includes many laboratory studies and three full scale applications to real waste sludge.

A goal of this report was to identify all relevant studies of high level waste sludge dissolution and to review those studies to collect the information that will form the technical basis for a recommendation for how to dissolve sludge in SRS high level waste tanks. Although a fairly wide variety of chemicals have been tested over the years, oxalic acid appears to be the best choice for waste tank application.

The studies reviewed in this section include a tremendous amount of useful information, but it is important to understand the limitations of each one. Studies performed with sludge simulants can be used to provide useful information but there are significant differences between real and simulated sludges. Tight control of parameters such as temperature, mixing, and solution to sludge ratios can be achieved in the lab but can be difficult or impossible to control in a waste tank.

Applications to real waste provide the most relevant information but the data collected from these studies is limited by the radioactive nature of the sludge. There have been three full scale applications of sludge dissolution. All three used oxalic acid. Two of the three were performed at the Savannah River Site; they are listed below:

- Oxalic acid cleaning of Tank 16H sludge in 1980.

- Oxalic acid treatment of Tank 24H zeolite in 1985.

- Hanford Tank C-106 sludge dissolution using oxalic acid in 2003 (currently in progress).

This section of the document presents the results of the review of the body of literature available on sludge dissolution. It is arranged by chemical and includes a discussion of the studies which provide information about that chemical. Essentially five different chemicals or chemical combinations have been evaluated. They include the following:

- Oxalic acid

- Citric Acid and Oxalic Acid/Citric Acid mixtures

- Oxalic Acid / Hydrogen Peroxide mixture

- Nitric Acid

- Other Organic Agents

The section concludes with a comparative evaluation of each chemical with respect to five broad categories that included: 
- Technology considerations

- Operability and logistical considerations

- Downstream facility impacts

- Safety issues associated with the authorization basis of the tank farm

- Regulatory or permitting issues

The score for oxalic acid was significantly higher than for any other chemical. This reflects both the relative level of knowledge of each chemical as well as the high degree of compatibility of oxalic acid with existing tank farm infrastructure such as carbon steel waste tanks.

\subsection{OXALIC ACID}

Oxalic acid has been widely tested and utilized as a sludge dissolution/removal agent at SRS and other DOE facilities. It provides the largest body of literature and experience in the sludge dissolution field. The following section contains a review (in no particular order) of the most relevant information.

\subsubsection{Chemical Cleaning of Porous Metal Filters}

Poirier and Fink conducted a series of tests investigating various cleaning agents for porous metal filters. ${ }^{30}$ Among the agents tested were oxalic acid, nitric acid, citric acid, and ascorbic acid. The tests involved placing simulated SRS High Level Waste Tank 40H sludge (5 g) and MST $(5 \mathrm{~g})$ in a beaker and adding the respective cleaning agent. Concentrations varied from agent to agent. The tests utilized $300 \mathrm{~mL}$ of cleaning agent solution. This volume provided a greater than 60:1 cleaning solution to sludge ratio. The addition of solution was followed by magnetic stirring of the resulting slurry at ambient temperature or $40{ }^{\circ} \mathrm{C}$, and collecting filtered supernate samples for analysis of the sludge constituents ( $\mathrm{Al}, \mathrm{Fe}, \mathrm{Mn}, \mathrm{Si}$, and $\mathrm{Ti}$ ) using Inductively Coupled Plasma Atomic Emission Spectroscopy (ICP-AES). A contact time of 1 hour was investigated. The tests did not involve multiple contacts (i.e., strikes) Table 9 shows the sludge composition. Results from the tests are provided graphically in Figure 1.

Table 9 Composition of specific elements of interest in Simulated Tank 40H sludge

\begin{tabular}{|l|c|}
\hline Constituent & Simulated Sludge, $\boldsymbol{\mu g} / \mathbf{g}$ \\
\hline Aluminum & 42,900 \\
\hline Iron & 174,900 \\
\hline Manganese & 6,900 \\
\hline Silicon & 6,000 \\
\hline Titanium & 171,300 \\
\hline
\end{tabular}

The tests were performed at short contact times, moderate temperatures, and in some cases with cleaning agent concentrations (specifically $4 \mathrm{M}$ nitric acid) that were designed for dissolution of sludge from a stainless steel filter tube. Even though these conditions are not optimal for sludge dissolution in a waste tank, they offer a degree of comparison that is not otherwise found in the literature. The data show that under the conditions tested, $0.5 \mathrm{M}(4.5 \mathrm{wt} \%)$ oxalic acid offers the 


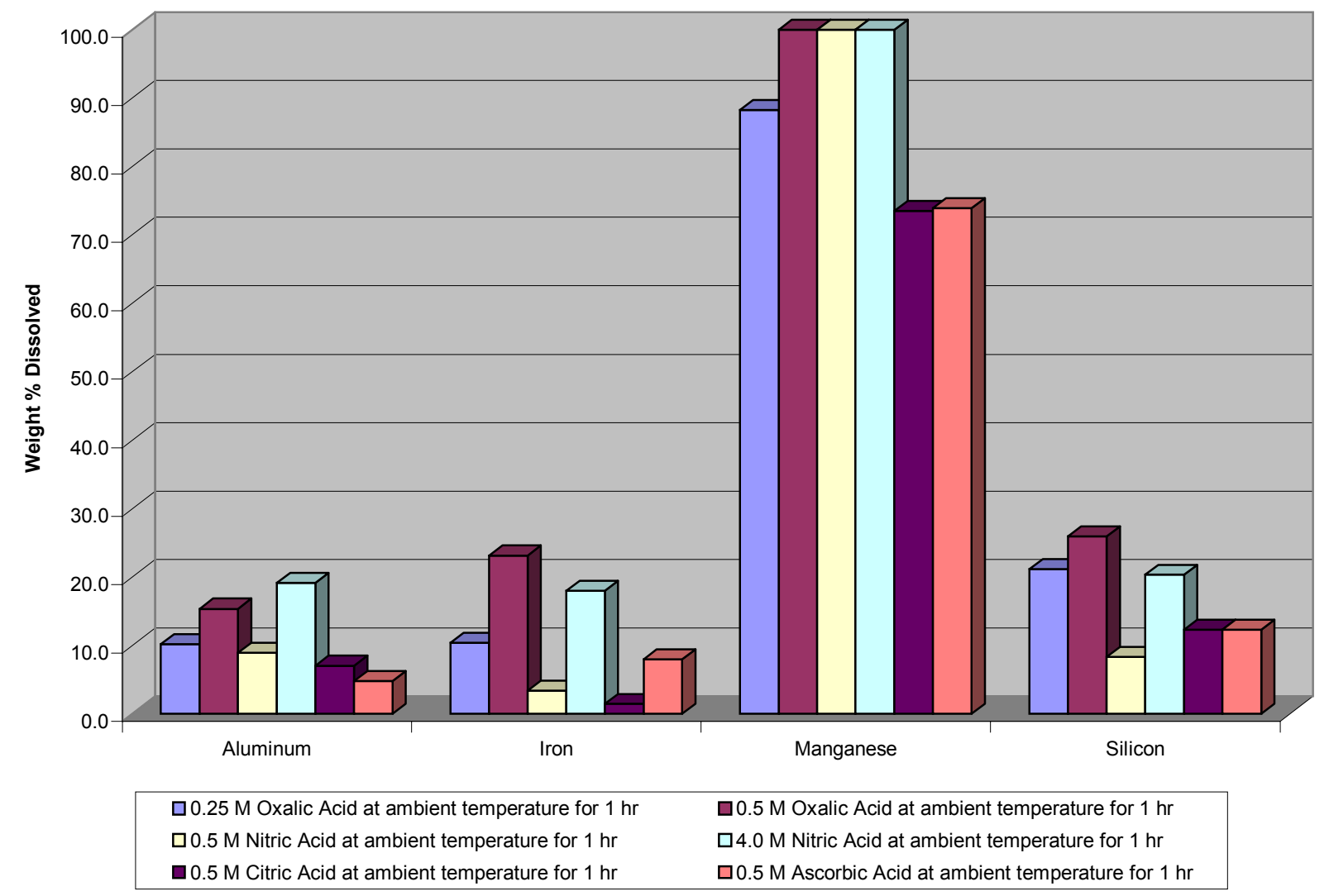

Figure 1 Effect of Various Cleaning Agents on Dissolution of Sludge Species

best removal results (excluding $4 \mathrm{M}$ nitric acid which is likely unacceptable for waste tank cleaning). Each of the cleaning agents are further examined for effectiveness with respect to concentration, temperature, contact time, etc. in later sections of this document.

Poirier and Fink ${ }^{30}$ found that $0.5 \mathrm{M}$ oxalic acid offered the best comparative results with tests of oxalic acid, nitric acid, citric acid, and ascorbic acid. In response to the results, further tests were conducted that explored the effect of additional variables, specifically temperature and contact time. The tests were conducted in a similar manner to those identified earlier. The tests involved placing either simulated SRS High Level Waste Tank 40H sludge (5 g) and MST (5 g) or actual SRS High Level Waste Tank 8F sludge (1 g) and MST (1 g) in a beaker and adding either $0.25 \mathrm{M}(2.2 \mathrm{wt} \%)$ or $0.5 \mathrm{M}(4.5 \mathrm{wt} \%)$ oxalic acid $(300 \mathrm{~mL}$ for simulated sludge and 60 $\mathrm{mL}$ for actual sludge). These volumes provided a greater than 60:1 cleaning solution to sludge ratio. (The high ratio reflects the nature of project. These tests were designed to determine how well the oxalic acid would clean filter tube bundles that contained small quantities of sludge.) This was followed by magnetic stirring of the resulting slurry at ambient temperature or $40{ }^{\circ} \mathrm{C}$, and periodically collecting filtered supernate samples for analysis of the sludge constituents (Al, $\mathrm{Fe}, \mathrm{Mn}, \mathrm{Si}$, and Ti) using Inductively Coupled Plasma Atomic Emission Spectroscopy (ICPAES). Contact times of 1 and 8 hours were investigated. The tests did not involve multiple contacts (i.e., strikes). Table 10 shows the sludge compositions. Results from the tests are provided graphically in Figure 2. 
Table 10 Composition of Specific Elements of Interest in Test Sludges

\begin{tabular}{|l|c|c|}
\hline Constituent & Simulated Sludge, $\boldsymbol{\mu g} / \mathbf{g}$ & Actual Waste Sludge, $\boldsymbol{\mu g} / \mathbf{g}$ \\
\hline Aluminum & 42,900 & 9,780 \\
\hline Iron & 174,900 & 69,000 \\
\hline Manganese & 6,900 & 12,510 \\
\hline Silicon & 6,000 & 3,570 \\
\hline Titanium & 171,300 & 240,000 \\
\hline
\end{tabular}



Figure 2 Effect of Oxalic Acid Concentration, Temperature, and Contact Time on Dissolution of Sludge Species

Conclusions from the tests were as follows:

- Increasing oxalic acid concentration enhanced sludge dissolution.

- Increasing the temperature increased the amount of sludge dissolved.

- Increasing the contact time increased the amount of sludge dissolved.

- For a $0.5 \mathrm{M}$ nitric acid solution, the effect of increasing temperature from ambient to 40 ${ }^{\circ} \mathrm{C}$ is roughly the same as increasing contact time from 1 to 8 hours.

- In general, oxalic acid was very effective on manganese and titanium and less effective with respect to aluminum, iron and silicon. 
- Increasing all three variables (concentration, temperature, and contact time) significantly increased the amount of aluminum dissolved.

- Actual Tank 8F sludge species (with the exception of manganese) were easier to dissolve than simulated sludge.

\subsubsection{Laboratory Tests in Support of Tank 16H Heel Cleaning}

Bradley and Hill reported on the results of a series of lab scale tests conducted in support of the oxalic acid treatment of sludge heel residue in Tank $16 \mathrm{H}^{31}$ They performed three sets of tests: (1) short term scoping tests with actual Tank $16 \mathrm{H}$ sludge and various cleaning agents, (2) short term tests of oxalic acid with simulated aluminum hydroxide, iron hydroxide, and manganese dioxide, and (3) long term tests with actual Tank 16H sludge.

\subsubsection{Short Term Tank 16H Sludge Tests}

The tests involved mixing $1-2 \mathrm{~mL}$ of actual Tank $16 \mathrm{H}$ sludge with $10 \mathrm{~mL}$ of cleaning agent (10 wt \% EDTA, $20 \mathrm{wt} \%$ glycolic and formic acid mixture, 6 wt \% sulfamic acid, 6 wt \% citric acid, 5 and $10 \mathrm{wt} \%$ sulfuric acid, and Turco Decon $4518 \AA$ (primarily 8 wt \% oxalic acid)) at ambient temperature $\left(\sim 25^{\circ} \mathrm{C}\right)$ for 30 minutes with agitation. Prior to testing, the sludge was thoroughly washed with water and centrifuged. It was used in a wet state. The contact phase of the tests was followed by centrifuging, measuring the sludge volume, and decanting the supernatant solution. Water was then added and the previous procedures repeated. In most instances, a second successive treatment was repeated. The amount of sludge dissolved was determined from the initial and final volumes (single or successive treatments) of wet centrifuged sludge. The composition of the actual waste Tank $16 \mathrm{H}$ sludge is given in Table 11.

Table 11 Composition of Washed and Dried Tank 16H Sludge

\begin{tabular}{|l|c|}
\hline Constituent & Wt \% \\
\hline $\mathrm{AlO}_{2}{ }^{-}$ & 16 \\
\hline $\mathrm{Fe}^{3+}$ & 40 \\
\hline $\mathrm{MnO}_{2}$ & 16 \\
\hline $\mathrm{Na}^{+}$ & 20 \\
\hline $\mathrm{SO}_{4}{ }^{2-}$ & 1.1 \\
\hline $\mathrm{Si}^{4+}$ & 2.0 \\
\hline
\end{tabular}

\begin{tabular}{|c|c|}
\hline Constituent & Wt \% \\
\hline $\mathrm{Ba}^{2+}$ & 1.0 \\
\hline $\mathrm{Ca}^{2+}$ & 1.0 \\
\hline $\mathrm{Ce}^{4+}$ & 1.0 \\
\hline $\mathrm{Hg}^{2+}$ & 2.5 \\
\hline $\mathrm{UO}_{2}{ }^{2+}$ & 0.4 \\
\hline
\end{tabular}

The conclusions from the tests were as follows.

- The oxalic acid based chemical agents dissolved the most sludge (nearly 70 vol. \%).

- Sulfuric and citric acid performed equally as well ( 60 vol. \% dissolved).

- Sulfamic acid and the mixture of glycolic and formic acid dissolved approximately 50 volume percent of the sludge.

- EDTA and a decon agent containing sulfamic and citric acid yielded only a 20 volume \% reduction of the sludge. 
It was reported that additional tests showed that omitting the water rinse between the two oxalic acid agent treatments reduced the volume $\%$ of sludge dissolved from $\sim 70 \%$ to $53 \%$. Earlier tests had indicated that soluble salts made up a significant fraction of the sludge. Presumably, the first strike with acid sufficiently exposed the bulk of sludge material so that the water rinse removed a significant fraction of salt. Furthermore, doubling or halving the volume of cleaning agent did not significantly change the amount of sludge dissolved. In addition, decreasing the concentration of oxalic acid agent from $8 \mathrm{wt} \%$ to $5 \mathrm{wt} \%$ had no adverse effect. Likewise, increasing the concentration to $16 \mathrm{wt} \%$ was ineffective. However, reducing the concentration to $3 \mathrm{wt} \%$ halved the volume of sludge dissolved.

Further tests were performed to compare the oxalic acid agent (Decon 4518) with pure oxalic acid solutions. No substantive difference was observed. Based upon these scoping tests, oxalic acid was focused upon for the remainder of their work. Observations obtained from the followup work showed the following.

- Continuous agitation increased the dissolution rate $\sim 30 \%$.

- Increasing temperature from 25 to $85{ }^{\circ} \mathrm{C}$ increases the rate of dissolution $\sim 40 \%$.

- The dissolution rate is directly proportional to the initial volume ratio of cleaning solution to sludge.

\subsubsection{Tests of Oxalic Acid with Simulated Sludge Materials}

Aluminum hydroxide, ferric hydroxide, and manganese dioxide were prepared and tested with oxalic acid. The test protocol was similar to that reported in the previous section except contact times were lengthened to 6 hours. Tests varied the volume ratio of oxalic acid to sludge material $(10,20$, and $40: 1)$ as well as the concentration of oxalic acid (4 and $8 \mathrm{wt} \%)$. The temperature of the tests was $80^{\circ} \mathrm{C}$. Results of the tests are shown in Figure 3. It should be noted that these tests were single sludge component tests (i.e., performed with one metal oxide or hydroxide present in each test) and therefore yielded non-competitive results.

Conclusions drawn from the tests are as follows:

- For aluminum hydroxide, $8 \mathrm{wt} \%$ oxalic acid and a solution to sludge volume ratio of at least 20 are required for complete dissolution.

- For ferric hydroxide, $8 \mathrm{wt} \%$ oxalic acid and a solution to sludge volume ratio of 40 are required for complete dissolution. At the same oxalic acid concentration, the solution to sludge volume ratio of 10 yielded nearly $70 \%$ dissolution.

- For manganese dioxide, only $8 \mathrm{wt} \%$ oxalic acid and a solution to sludge volume ratio of 40 resulted in a significant amount of dissolution. This implies longer contact times and possibly high solution to sludge volume ratios would be needed for complete dissolution of high manganese solutions.

It is difficult to compare the data in Figure 3 with those of Poirier and Fink ${ }^{30}$ (Figure 2) because the experimental conditions were different $(\sim 4.5 \mathrm{wt} \%$ oxalic acid, contact time of 8 hours, temperature of $40{ }^{\circ} \mathrm{C}$, and solution to sludge ratio of greater than 60:1). Also, the specific sludge 


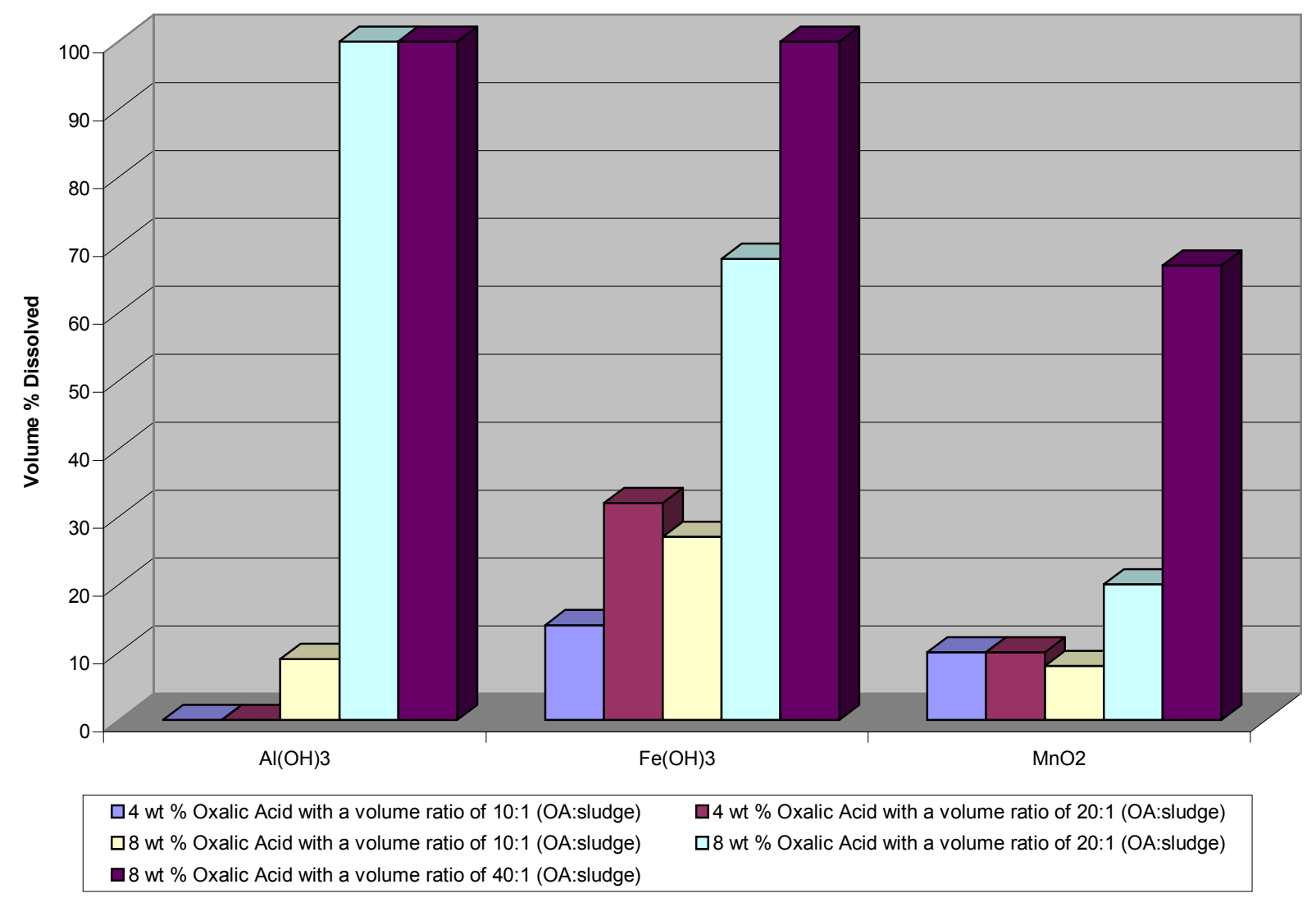

Figure 3 Effect of Oxalic Acid Concentration and Solution to Sludge Volume ratio on Simulated Sludge Material (Contact time of 6 hours at $80^{\circ} \mathrm{C}$ )

compounds were not given in Poirier and Fink's study. However, a seemingly notable contradiction is that while manganese was readily dissolved in the Poirier and Fink's study, it was the most difficult to dissolve in Bradley and Hill's work. ${ }^{31}$ Both sets of tests generally agree that increased temperature, contact time, and oxalic acid concentration yield the best overall sludge dissolution results.

\subsubsection{Long Term Contact Tests with Actual Tank 16H Sludge}

Tests were conducted with oxalic acid and actual Tank $16 \mathrm{H}$ sludge to examine the efficiency of long term contacts on sludge dissolution. Tests were conducted at $85{ }^{\circ} \mathrm{C}$ using $8 \mathrm{wt} \%$ oxalic acid for extended periods of time. Multiple step experiments with final oxalic acid to sludge ratios as high as 80:1 and contact times as long as 186 hours were conducted. Results showed that two successive contacts of 50 hours per contact with agitation at $85{ }^{\circ} \mathrm{C}$ using $8 \mathrm{wt} \%$ oxalic acid and at least a solution to sludge volume ratio of 40 dissolved over $96 \%$ of the sludge. Longer contact times and higher solution to sludge volume ratios did not result in significant gains in dissolution. 


\subsubsection{Digestion Tests with Tank 16H Sludge}

Holtzscheiter performed a series of tests with actual Tank $16 \mathrm{H}$ sludge to further characterize the performance of sludge dissolution under conditions that were expected to more closely simulate actual Tank $16 \mathrm{H}$ cleaning operations. ${ }^{32}$ The experimental procedure for sludge dissolution was the same as outlined for Bradley and Hill's work. ${ }^{31}$ The only exception was that in some tests the sludge was dried and rewetted with water before oxalic acid was added. Results are summarized in Table 12.

Table 12 Actual Tank 16H Waste Sludge (Raw and Dried Dissolution Data)

\begin{tabular}{|c|c|c|c|c|}
\hline $\begin{array}{c}\text { Concentration } \\
\text { of Oxalic Acid, } \\
\text { Wt } \%\end{array}$ & $\begin{array}{c}\text { Volume Ratio, } \\
\text { Oxalic } \\
\text { Acid/Sludge } \\
\end{array}$ & $\frac{\text { Temperature, }}{{ }^{\circ} \mathrm{C}}$ & $\begin{array}{l}\text { Time of Each } \\
3 \text { Successive } \\
\text { Steps, hours }\end{array}$ & $\begin{array}{c}\text { Total Sludge } \\
\text { Dissolved, Vol. } \\
\%\end{array}$ \\
\hline \multicolumn{5}{|c|}{ Actual Tank 16H Waste Sludge - Raw } \\
\hline 4 & $30: 1$ & 85 & 1,9, and 15 & $>99$ \\
\hline \multicolumn{5}{|c|}{ Actual Tank 16H Waste Sludge- Dried } \\
\hline 4 & $30: 1$ & $\begin{array}{c}\text { Room } \\
\text { temperature }\end{array}$ & 1,9 , and 15 & $\sim 70$ \\
\hline 4 & $30: 1$ & 50 & 1,9, and 15 & $\sim 70$ \\
\hline 4 & $30: 1$ & 85 & 1,9 , and 15 & 92 \\
\hline 2 & $30: 1$ & 85 & 1,9, and 15 & 70 \\
\hline $4 *$ & $30: 1$ & 85 & 10 & $81^{*}$ \\
\hline
\end{tabular}

* Tests performed with residual solids from the test with $2 \mathrm{wt} \%$ oxalic acid. Value reported for the total sludge dissolved represents dissolution after a $4^{\text {th }} 10$-hour successive step using $4 \mathrm{wt} \%$ oxalic acid at the end of the 25 -hour 3 -step process from the previous row.

The conclusions from these tests were as follows:

- Increasing oxalic acid to sludge volume ratios from 30:1 to 60:1 resulted in no appreciable gain in sludge dissolutions. (Actual data was not documented to validate this conclusion.)

- Use of dried sludge yielded lower dissolutions than raw sludge.

- Increased temperatures improved the volume of sludge dissolved.

- Using only 4 wt \% oxalic acid in a 25-hour 3-step dissolution is more effective than using $2 \mathrm{wt} \%$ oxalic acid in a 25 -hour 3 -step dissolution followed by 10 -hour dissolution using $4 \mathrm{wt} \%$ oxalic acid.

\subsubsection{Oxalic Acid Cleaning of Tank 24H}

This report by Fong details the results of the full scale oxalic acid cleaning demonstration of Tank $24 \mathrm{H}^{33}$ The demonstration attempted to remove 11,000 gallons of residual zeolite material that remained following the completion of salt removal operations. The steps were as follows.

1. Operations added 22,500 gallons of $8 \mathrm{wt} \%$ oxalic acid to the heel in tank $24 \mathrm{H}$.

2. Soon after, 12,000 gallons of water were added. The water dilution reduced the concentration of acid to $5.2 \mathrm{wt} \%$ and produced a solution to solids volume ratio of $\sim 3$. 
3. The solution was agitated for 3 days and then neutralized (in situ) with $50 \mathrm{wt} \%$ sodium hydroxide.

4. The neutralized solution was transferred to Tank $38 \mathrm{H}$ and eventually evaporated.

5. The residual heel in Tank $24 \mathrm{H}$ was rinsed with 9,600 gallons of water for 2 hours and a second time with 19,100 gallons of water for 1 day. The rinse water was transferred to Tank $38 \mathrm{H}$ each time.

6. A second oxalic acid wash was initiated 15 days after the first oxalic acid wash was started. Operations added 23,500 gallons of $8 \mathrm{wt} \%$ oxalic acid to the 13,000 gallon heel in Tank $24 \mathrm{H}$. No additional dilution water was added. The volume ratio of solution to solid was slightly less than 2 . The oxalic acid solution was agitated continuously for 3 days.

7. The oxalic acid solution was neutralized again in situ with 2400 gallons of $50 \mathrm{wt} \%$ sodium hydroxide and transferred to Tank $38 \mathrm{H}$.

Note that the report provided no data regarding temperature during this demonstration.

Tank $24 \mathrm{H}$ was closely monitored and sampled throughout the acid cleaning demonstration. Results indicate that all the added oxalic acid in the first contact completely reacted. Large amounts of unreacted zeolite remained after the first contact. The composition of the zeolite was found to have changed to a compound similar to hydroxy sodalite (rough composition: $\left.3\left(\mathrm{NaAlO}_{2} \cdot \mathrm{SiO}_{2}\right) \cdot 3 \mathrm{NaOH} \cdot \mathrm{NaNO}_{3} \cdot 12 \mathrm{H}_{2} \mathrm{O}\right)$. It is likely that the large quantities of intercalated sodium hydroxide reacted with much of the oxalic acid.

The oxalic acid-zeolite reaction during the second contact did not apparently consume all of the oxalic acid. Results indicate that only one of the two hydrogen equivalents in oxalic acid had been neutralized. It was believed that loose solids reacted while a densely packed solid remained. Upon neutralization, soluble sodium aluminate and sodium silicate formed. These compounds then likely reacted to form an aluminosilicate gel. The formation of the gel did not hinder solids removal since the solids were easily slurried and transferred out of the tank. In general, results from the sampling program showed the dissolution results were marginal (at best). About $5 \mathrm{wt} \%$ of the zeolite was removed. The marginal results may have stemmed from any of the following (or even others not identified).

- Poor chemical reactivity.

- Low cleaning temperature.

- Low oxalic acid to sludge volume ratios.

\subsubsection{Oxalic Acid Cleaning of Tank 16H}

This report by West documents the results of the full scale oxalic acid cleaning demonstration conducted at SRS on Tank $16 \mathrm{H}^{2}{ }^{2}$ The demonstration included two water washes, three oxalic acid contacts, and a final water rinse as shown in Table 13 below. The demonstration removed $99.9 \%$ of the radioactive waste from the tank. Inspection of the bottom of the tank after drying revealed no significant sludge or salt deposits. Note that the steps utilized in this demonstration were designed to provide data and experience to evaluate waste treatment options for other tanks. They were not necessarily the most expeditious or efficient steps necessary to clean the tank. 
Table 13 Test Conditions for Tank 16 Cleaning Demonstration

\begin{tabular}{|c|c|c|c|c|}
\hline $\begin{array}{l}\text { Process } \\
\text { Step }\end{array}$ & $\begin{array}{l}\text { Method and Type of } \\
\text { Solutions Added to } \\
\text { Tank }\end{array}$ & $\begin{array}{c}\text { Volume of } \\
\text { Solution, Gal }\end{array}$ & $\begin{array}{c}\text { Oxalic Acid to } \\
\text { Sludge Volume } \\
\text { Ratio** } \\
\end{array}$ & $\begin{array}{l}\text { Time, } \\
\text { hours }\end{array}$ \\
\hline $\begin{array}{l}1^{\text {st }} \text { water } \\
\text { wash }\end{array}$ & Sprayed $90{ }^{\circ} \mathrm{C}$ water & 63,000 & $\mathrm{n} / \mathrm{a}$ & 48 \\
\hline $\begin{array}{l}2^{\text {nd }} \text { water } \\
\text { wash }\end{array}$ & Sprayed $90{ }^{\circ} \mathrm{C}$ water & 70,000 & $\mathrm{n} / \mathrm{a}$ & 30 \\
\hline $\begin{array}{l}1^{\text {st }} \text { acid } \\
\text { contact }\end{array}$ & $\begin{array}{l}{ }^{*} \text { Sprayed } 90{ }^{\circ} \mathrm{C} \\
\text { water/Pumped } 90{ }^{\circ} \mathrm{C} \\
4 \mathrm{wt} \% \text { acid }\end{array}$ & $41,500 / 12,600$ & 39 & 48 \\
\hline $\begin{array}{l}\text { 2nd acid } \\
\text { contact }\end{array}$ & $\begin{array}{l}{ }^{*} \text { Sprayed } 90{ }^{\circ} \mathrm{C} \text { water/ } \\
\text { Sprayed } 90{ }^{\circ} \mathrm{C} 4 \text { wt } \% \\
\text { acid }\end{array}$ & $46,400 / 10,000$ & 41 & 40 \\
\hline $\begin{array}{l}3^{\text {rd }} \text { acid } \\
\text { contact }\end{array}$ & $\begin{array}{l}\text { Sprayed } 90{ }^{\circ} \mathrm{C} 4 \text { wt \% } \\
\text { acid }\end{array}$ & 50,000 & 36 & 48 \\
\hline $\begin{array}{l}\text { Water } \\
\text { rinse }\end{array}$ & $\begin{array}{l}\text { Sprayed } 90{ }^{\circ} \mathrm{C} \\
\text { water } / \text { Sprayed } 25{ }^{\circ} \mathrm{C} \\
\text { water }\end{array}$ & $56,000 / 56,000$ & $\mathrm{n} / \mathrm{a}$ & $\begin{array}{l}\text { Not } \\
\text { given }\end{array}$ \\
\hline
\end{tabular}

$*$ Results in oxalic acid concentration of $\sim 1 \mathrm{wt} \%$

**All ratios are based upon the original sludge volume in tank (1380 gal.)

Note: Solution from each process step was neutralized to $\mathrm{pH}>12$ with $50 \mathrm{wt} \% \mathrm{NaOH}$ outside of Tank 16 before being transferred to Tank $21 \mathrm{H}$.

The initial step in the Tank $16 \mathrm{H}$ Heel cleaning demonstration was transfer of Tank $22 \mathrm{H}$ supernate into Tank $16 \mathrm{H}$. This was performed to prime the slurry pumps in Tank $16 \mathrm{H}$ and to facilitate the removal of as much residual sludge (estimated at $\sim 1380$ gallons) as possible. Prior to the transfer, several small piles of sludge were visible beneath a riser. The transfer into Tank $16 \mathrm{H}$, the subsequent pump operation, and transfer out to tank $21 \mathrm{H}$ left less than $1 \%$ of the sludge.

The water wash and oxalic acid contacts were performed using spray jets in all instances except one (where the acid was added directly to the tank contents on the bottom to specifically aid in the removal of radioactive materials from sludge contained in the bottom of the tank). All transfers out of Tank $16 \mathrm{H}$ were continuously neutralized to $\mathrm{pH}>12$ by adding $50 \% \mathrm{NaOH}$ to pump tank 4 (HPT-4). Throughout the washing stages, photographs were taken. The photographs indicated the presence of a salt deposit on a cooling coil. After the third acid contact, approximately 100 gallons of sludge-like material remained. The material was sampled and found to contain mostly hematite and boehmite. The solid sample was found to be insoluble in $50{ }^{\circ} \mathrm{C}$ oxalic acid (no concentration identified). The ${ }^{239} \mathrm{Pu}$ concentration in the sludge solid was about twice $(0.14 \mathrm{~g} / \mathrm{L})$ that of the original sludge but well below that required for criticality $(7 \mathrm{~g} / \mathrm{L}) .{ }^{2}$ The ${ }^{90} \mathrm{Sr}$ concentration was approximately three times greater than that of the original sludge. No significant sludge or salt deposits remained after the final water rinse. The tank bottom was coated with a thin yellow material (assumed to be ferrous oxalate). Analysis of residue that dried in Tank $16 \mathrm{H}$ showed the primary radioactive material remaining in Tank $16 \mathrm{H}$ was ${ }^{90} \mathrm{Sr}(87 \mathrm{mCi} / \mathrm{g})$. The ${ }^{137} \mathrm{Cs}$ and ${ }^{238 / 239} \mathrm{Pu}$ concentrations were 0.004 and $0.006 \mathrm{mCi} / \mathrm{g}$, respectively. 
This full scale demonstration fairly corroborates the Bradley and Hill ${ }^{31}$ long term tests using actual Tank $16 \mathrm{H}$ waste sludge. Note that the contact time, temperature, and the oxalic acid to sludge volume ratios in this full scale demonstration and Bradley and Hill's work were roughly the same. The major difference in the two tests is that Bradley and Hill used a higher concentration of oxalic acid (i.e., $8 \mathrm{wt} \%$ versus $1 \mathrm{wt} \%$ in the full scale demonstration).

\subsubsection{Laboratory Scale Testing at Hanford}

D. B. Bechtold, et. al, of the Fluor Hanford Company recently (in 2002/2003) performed oxalic acid dissolution tests using Hanford site Tank 241-C-106 Sludge and Tank AY-102 (surrogate for C-106 sludge). ${ }^{34}$ The experimental procedure for sludge dissolution was the same as the one outlined for the Bradley and Hill's work ${ }^{31}$ except the amount of sludge dissolved was based on weight instead of volume. All the tests were done at room temperature $\left(\sim 23{ }^{\circ} \mathrm{C}\right)$ using $1 \mathrm{M}(9 \mathrm{wt}$ $\%$ ) oxalic acid. The tests were performed in two phases of testing.

Phase I studies constituted "Feasibility Testing" performed to assess whether significant sludge dissolution was feasible. The Phase I testing experienced leakage problems which confounded the results. However, post-testing analysis showed that $50-70 \%$ by weight of the sludge was dissolved in both solutions of oxalic acid alone and a mixture of oxalic and nitric acid. The mixed acid was only slightly more effective than oxalic acid alone.

Phase II studies were identified as "Process Development" tests designed to examine (1) the optimum acid to sludge ratio, (2) dissolution kinetics, (3) batchwise addition of acid, (4) gas release, and (5) impacts on the Double Shell tank System. Results from the first two test sets from this phase are shown in Figure 4 and Figure 5. Results from all five test sets are summarized later in the section.

Figure 4 below provides a very nice graphical representation of the behavior of selected sludge components with respect to oxalic acid to sludge ratio. All tests utilized $1.0 \mathrm{M}(9 \mathrm{wt} \%)$ oxalic acid with a contact time of 9 days. The tests were conducted at ambient temperature. The tests show that the major sludge components (sodium, aluminum, iron, manganese, and silicon) exhibit a similar trend. The dissolution of each species (except sodium), as well as the sludge as a whole, is maximized with an oxalic acid to sludge ratio of 17.5.

Figure 5 provides a graphical representation of the kinetics of sludge dissolution. The tests were performed with 1.0 M oxalic acid at a solution to sludge ratio of 17.5. In general, two types of dissolution were observed. The total weight of sludge, sodium, and silicon that dissolved did not change appreciably over the 18 days of testing. Iron, and to a lesser extent aluminum and manganese increased throughout the entire test period. The lack of weight loss for the sludge is odd since it should decrease with the increasing dissolution of the iron, aluminum, and manganese from the sludge. The authors speculate that substitution of oxalate for oxide/hydroxide in the undissolved solids could possibly explain this effect (because oxalate weighs more than oxide/hydroxide). In addition, the graph demonstrates that agitation of the test mixtures did not significantly affect dissolution. 


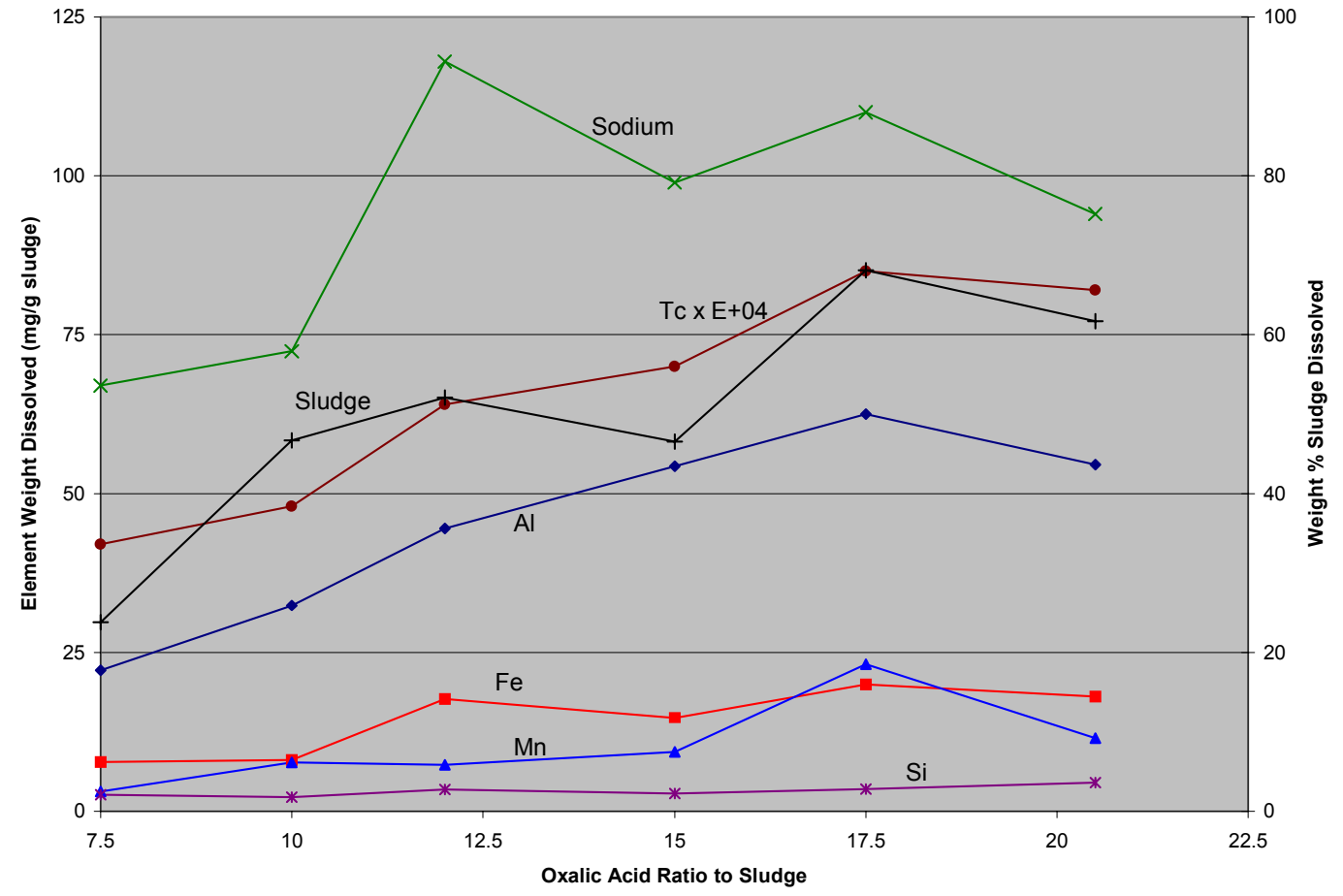

Figure 4 Sludge Components Dissolved as a Function of the Oxalic Acid to Sludge Volume Ratio

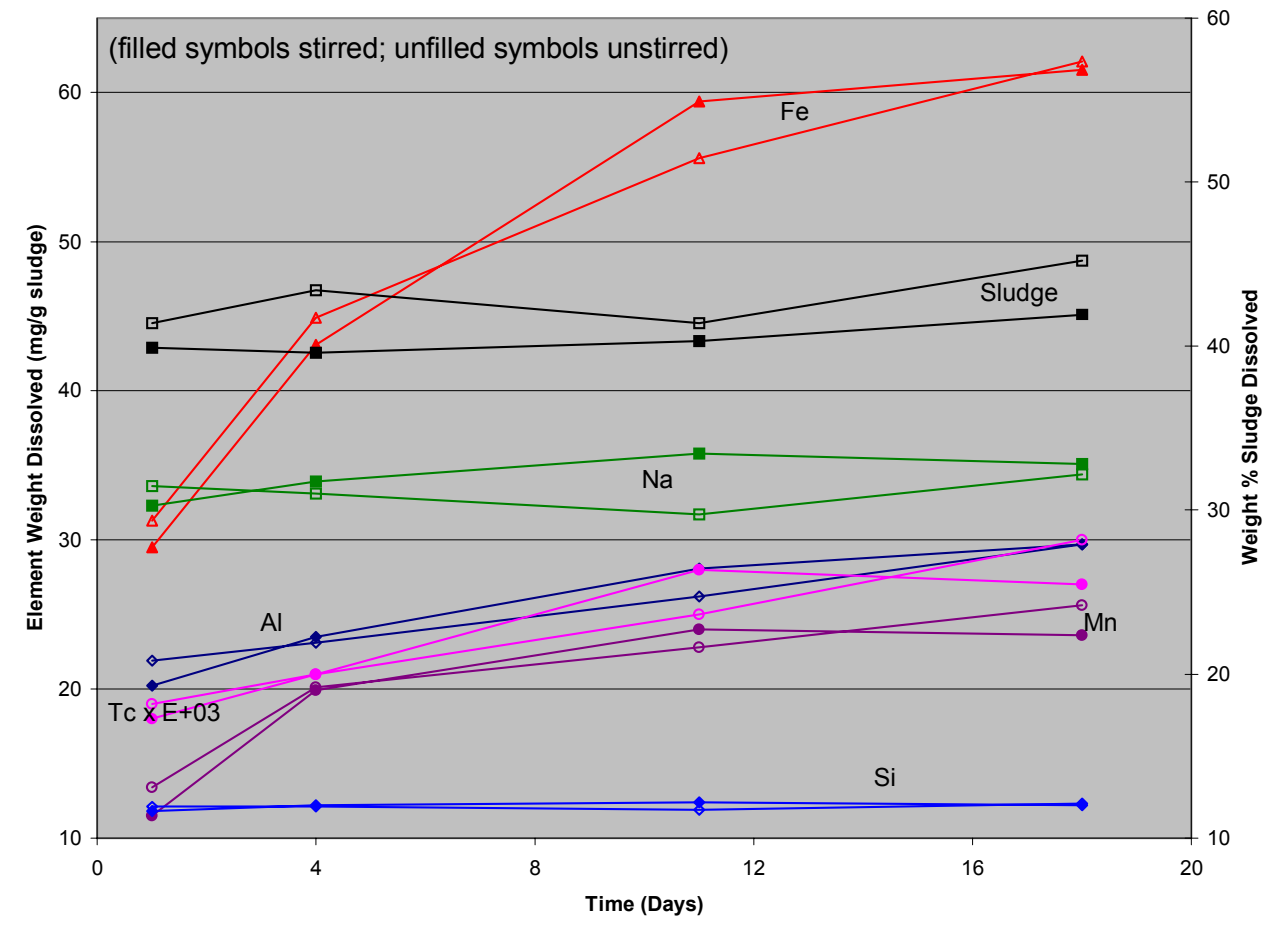

Figure 5 Dissolution of Sludge Components as a Function of Time 
The conclusions from the Phase II tests were as follows.

- Within the range of oxalic acid to sludge volume ratios of 7.5 to 20 , the maximum sludge dissolution ( $68 \mathrm{wt} \%$ ) occurred at acid to sludge volume ratio of 17.5.

- Kinetics tests indicated the total weight of sludge dissolved and amounts of $\mathrm{Na}, \mathrm{Si},{ }^{137} \mathrm{Cs}$, and ${ }^{90} \mathrm{Sr}$ in solution were approximately the same for contact times of 1 and 18 days. The amounts of $\mathrm{Fe}, \mathrm{Mn}$, and $\mathrm{Al}$ in solution increased throughout the entire 18 days. The former and the latter indicate fast and slow kinetics respectively.

- The total weight of sludge dissolved (68 wt \%) was independent of whether the oxalic acid was added in a single $35-\mathrm{mL} / 6$-hour batch or in three successive $12-\mathrm{mL} / 6$-hour batches.

- Nearly all of the gas produced by acidification of the sludge was $\mathrm{CO}_{2}$, with traces of $\mathrm{H}_{2}$ and $\mathrm{CH}_{4}$. The total volume of gas produced (at $1 \mathrm{~atm}$ and $25^{\circ} \mathrm{C}$ ) was $190 \mathrm{~mL}$ of gas per $\mathrm{mL}$ of sludge.

- Neutralization of the spent oxalic acid with simulated tank AN-106 supernatant liquid and $50 \mathrm{wt} \% \mathrm{NaOH}$ solution produced large volumes (130\% of the spent acid volume) of easily-compacted solids. The solids were identified as mainly $\mathrm{Na}_{3} \mathrm{PO}_{4} \cdot 12 \mathrm{H}_{2} \mathrm{O}$ and $\mathrm{Na}_{2} \mathrm{C}_{2} \mathrm{O}_{4}$.

- Solid phases identified in the pre-acidified sludge include $\mathrm{NaAlCO}_{3}(\mathrm{OH})_{2}$ (dawsonite), $\mathrm{Fe}_{2} \mathrm{O}_{3}$ (hematite), $\mathrm{Al}(\mathrm{OH})_{3}$ (gibbsite), $\mathrm{Na}_{6} \mathrm{Ca}_{1.5} \mathrm{AI}_{6} \mathrm{Si}_{6} \mathrm{O}_{24}\left(\mathrm{CO}_{3}\right)_{1.6}$ (cancrinite), and $\mathrm{Na}_{3} \mathrm{MnPO}_{4} \mathrm{CO}_{3}$ (sidorenkite). Solid phases identified in post-acidified residues include hematite, gibbsite, boehmite $[\mathrm{AIO}(\mathrm{OH})]$, and manganese(II) oxalate.

\subsection{CITRIC ACID}

The use of citric acid as a sludge dissolution agent has been studied in at least two prior comparison sets of research. Bradley and Hill ${ }^{31}$ conducted scoping tests with Tank $16 \mathrm{H}$ sludge and found citric acid as a lone cleaning agent to be slightly less effective than oxalic acid. Their test with it in a mixture with sulfamic acid yielded significantly reduced results. Poirier and Fink $^{30}$ performed comparison tests (see Figure 1) of other acids with simulated Tank $40 \mathrm{H}$ sludge and $0.5 \mathrm{M}$ citric acid at ambient temperature and high solution to sludge solid ratio $(>60)$. Like Bradley and Hill ${ }^{31}$, their results showed citric acid alone was less effective than oxalic acid. Recent testing has turned to the use of mixtures of oxalic acid and citric acid rather than the use of citric acid alone.

\subsubsection{Mixtures of Oxalic and Citric Acid}

The bulk of information and experience with using mixtures of oxalic and citric acid come from recent tests performed by the V. G. Khlopin Radium Institute, Mining-Chemical Combine (MCC), and SRTC (D. T. Hobbs and M. E. Stallings). Both groups worked in association with each other, conducting tests with simulated PUREX and H-area Modified (HM) sludges. SRTC performed additional studies utilizing actual tank waste sludge at high cleaning solution to sludge ratios. This work resides in draft (unissued) documents awaiting additional funding to complete. 
Scoping experiments on simulated and real waste PUREX and HM sludge were performed using an oxalic acid and citric acid mixture. The proposed activity was to evaluate the effectiveness of the organic acids to mobilize and dissolve simulant and actual sludge components. MCC and SRTC conducted tests with simulated PUREX and HM sludges prepared per standard recipes. Portions of each sludge type were stored at ambient laboratory temperature and at $80{ }^{\circ} \mathrm{C}$ for between 2 and 3 months to accelerate the effects of material aging. These two sludges closely resemble tank heel materials and sludges for those tanks that have been allowed to evaporate to dryness. The effects of higher temperature on the sludges, in addition to physical and chemical characteristics were then determined. Analytical results show excellent agreement between the theoretical elemental composition and the measured values for both the SRTC and Russian prepared PUREX sludges. The SRTC PUREX simulant contained a higher iron, manganese and nickel concentrations compared to the HM simulant. Aluminum proved the dominant element in the HM simulant. The results indicate poorer agreement between the theoretical and measured elemental composition for the HM sludge preparations. The Russian simulant measured high in aluminum and manganese and low in iron and nickel. Close evaluation of sludge components prepared at SRTC compared to those from MCC showed similar chemical constituents concentrations with the exception of aluminum and uranium. The concentration of uranium (12$60 \mathrm{wt} \%)$ in the MCC sludges was significantly higher than the SRTC uranium (1.3-11 wt \%) content. Aluminum concentrations in the SRTC sludges ( $6.5 \mathrm{wt} \%)$ were bounded by the MCC sludges (2.0-10 wt \%). These differences may reflect the final free hydroxide concentration of the slurry. In the case of the SRTC preparation, the final free hydroxide concentration was perhaps higher, resulting in more aluminum dissolved in solution leaving less aluminum in the sludge solids. Conversely, the Russian preparation was low in hydroxide concentration, resulting in less aluminum in solution and more aluminum in the sludge solids.

The general method used in all tests was to conduct a series of contacts of sludge solids with a mixtures of oxalic and citric acid. Dissolution of PUREX sludges featured an oxalic/citric acid solution comprised of $15 \mathrm{~g} / \mathrm{L}$ of oxalic acid $(0.167 \mathrm{M})$ and $15 \mathrm{~g} / \mathrm{L}$ of citric acid monohydrate $(0.071 \mathrm{M})$. Dissolution of HM sludge used a more dilute solution comprised of $5 \mathrm{~g} / \mathrm{L}$ oxalic acid $(0.056 \mathrm{M})$ and $5 \mathrm{~g} / \mathrm{L}$ citric acid monohydrate $(0.024 \mathrm{M})$. Acid solution to sludge ratios of $2: 1$ and 50:1 were examined. The test temperature was $60{ }^{\circ} \mathrm{C}$ and the contact time for the tests was 7 hours. After contacting, the liquid and solid phases were separated and the liquid phase analyzed to identify and quantify the dissolution of chemical and radiochemical components of the sludges. Additional contacts of the acid mixture and residual sludge solids was performed to simulate multiple strikes. Based on testing results at the $\mathrm{MCC}$, one of their recommendations was to reduce the aluminum content in HM sludge by caustic leachings prior to contact with the oxalic and citric acid mixture.

Results from the two sets of dissolution tests varied, even though the MCC scientists used simulant sludge recipes provided by SRTC. Complete dissolution of sludge solids was not achieved in any of the SRTC chemical cleaning tests, regardless of liquid to sludge ratio (2:1 and 50:1) or waste simulant used. This was contrary to the findings reported by the MCC. Results and observations from the two sets of tests are as follows. 
- Six sequential contacts of oxalic acid and citric acid solutions with simulated PUREX and HM sludges at 2:1 and 50:1 volume ratios dissolved between $26 \mathrm{wt} \%$ and $64 \mathrm{wt} \%$ of the sludge solids. The Russian dissolution study using oxalic acid and citric acid solutions with simulated PUREX and HM sludges at the 2:1 volume ratio dissolved 99.9 wt $\%$ of the sludge solids.

- As anticipated, increased sludge dissolution occurred at the higher acid to sludge volume ratio $(50: 1)$. Tests at the higher liquid to sludge ratio were not incorporated in the Russian studies.

- In both Russian and SRTC tests, sodium hydroxide leaching of the HM sludge before oxalic and citric acid contact resulted in $45 \mathrm{wt} \%$ dissolution of the aluminum from the sludge.

- Testing at SRTC failed to show that aluminum leaching with $\mathrm{NaOH}$ prior to contacting the sludge with the acid mixture improved the efficiency of the acid dissolution treatment.

- Treating SRS HLW sludges with citric acid and oxalic acid mixtures did not promote uniform dissolution of neutron poisons relative to that of fissile elements.

The low aluminum dissolution observed in the tests can be attributed to the high fraction of boehmite present in the simulated sludge. Boehmite exhibits a lower solubility in alkaline solutions. Consequently, sludge with higher fractions of boehmite require more rigorous conditions (e.g., higher hydroxide concentration and temperature) and longer leaching times to yield aluminum removal comparable to that observed with sludges rich in gibbsite. ${ }^{35}$

\subsection{OXALIC ACID WITH HYDROGEN PEROXIDE}

The use of hydrogen peroxide in conjunction with oxalic acid has been reported by Bibler. ${ }^{36}$ This report summarized a study investigating the possible use of hydrogen peroxide to enhance the cleaning effectiveness of $4 \mathrm{wt} \%$ oxalic acid on the inner surfaces of SRS HLW tanks. The oxalic acid cleaning demonstration of Tank $16 \mathrm{H}$ involved spraying $4 \mathrm{wt} \%$ oxalic acid at $90{ }^{\circ} \mathrm{C}$ on the tank's inner surfaces after cleaning with water. The enhancements with hydrogen peroxide were investigated at the bench scale level using a cooling coil sample cut from Tank $16 \mathrm{H}$ after the cleaning demonstration with water. The carbon steel cooling coil sample resembled a pillow with dimensions of 2" 24 " $\mathrm{x} 1$ ". The major contaminants on the surfaces included ${ }^{137} \mathrm{Cs},{ }^{137 \mathrm{~m}} \mathrm{Ba}$, ${ }^{90} \mathrm{Sr}$ and ${ }^{90} \mathrm{Y}$.

Each test entailed immersing the coil sample in a solution of either $4 \mathrm{wt} \%$ oxalic acid or $4 \mathrm{wt} \%$ oxalic acid containing 0.5 vol. $\%(\sim 0.15 \mathrm{M})$ hydrogen peroxide 20 times at 10 seconds per immersion. The sample was allowed to drain between immersions for 3 three minutes. The volume of solution was the same for all tests. Photographs of the cooling coil during various stages of the testing are shown in Figure 6, Figure 7, Figure 8, Figure 9 and Figure 10. Table 14 below gives a summary of the key findings. 




\section{Figure 6 Appearance of Tank 16 Coil Sample as Received}

This coil had been through the water spray cleaning in the Tank and was then cut from the 2 inch Schedule 40 mild steel pipe with a long crimping tool. The coil sample had been submerged in sludge for 10-20 years but was above the sludge level (sludge had been washed out) when cut and removed from the Tank. Note the rust. Dose rate from the sample was $40 \mathrm{R} / \mathrm{h}$ beta-gamma and $0.5 \mathrm{R} / \mathrm{h}$ gamma at 4 inches.

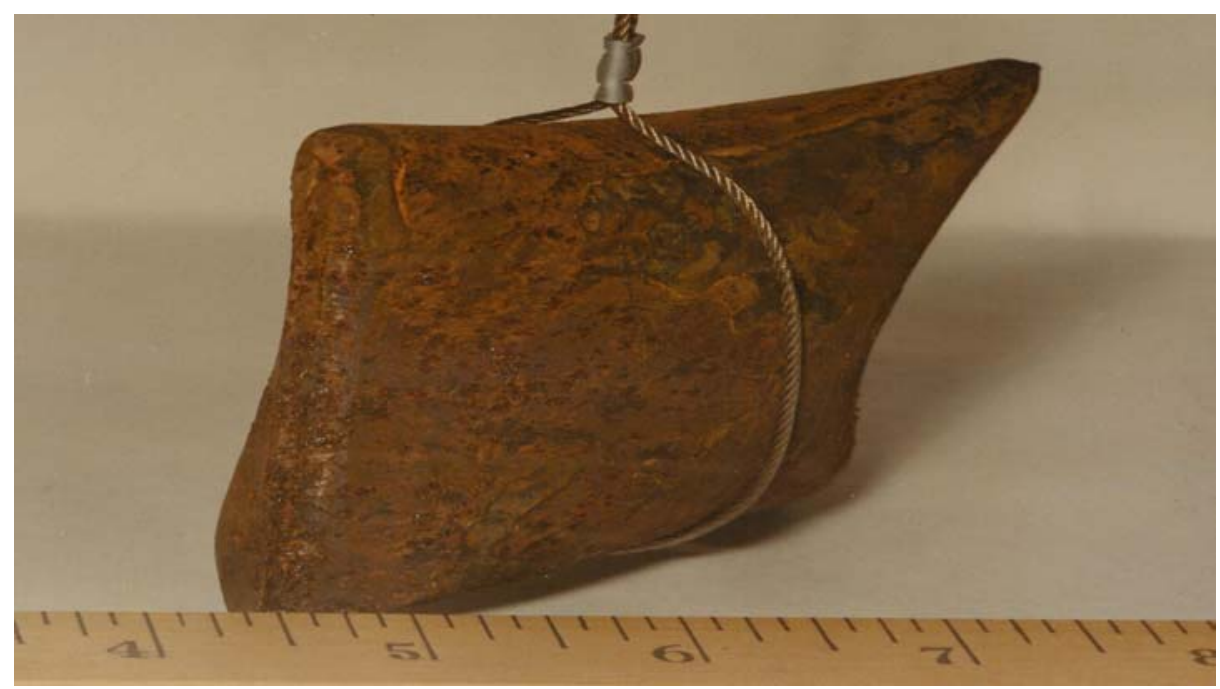

Figure 7 Close up of the Coil Sample

Again note the rust. 


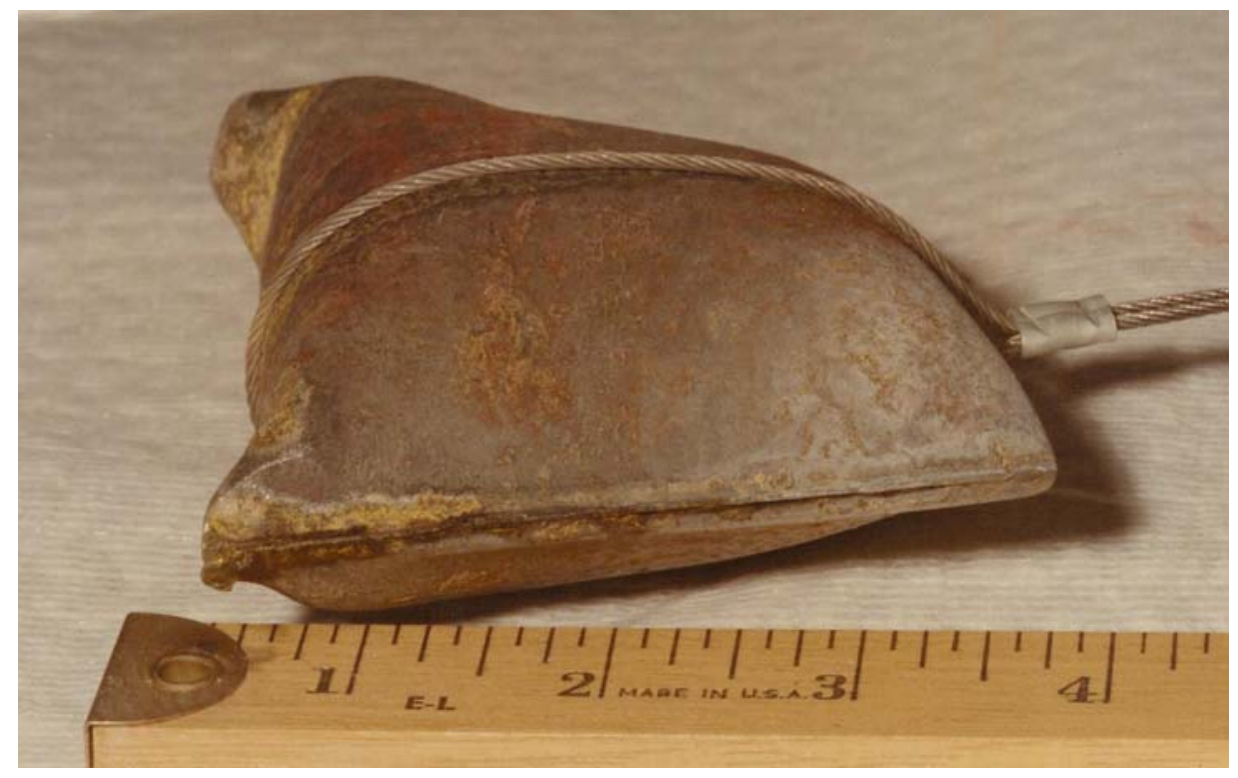

\section{Figure 8 Appearance after Six Tests with 4 wt \% Oxalic Acid}

Yellow deposits could be $\mathrm{FeC}_{2} \mathrm{O}_{4}$ which passivates the metal surface and inhibits further dissolution of the mild steel.

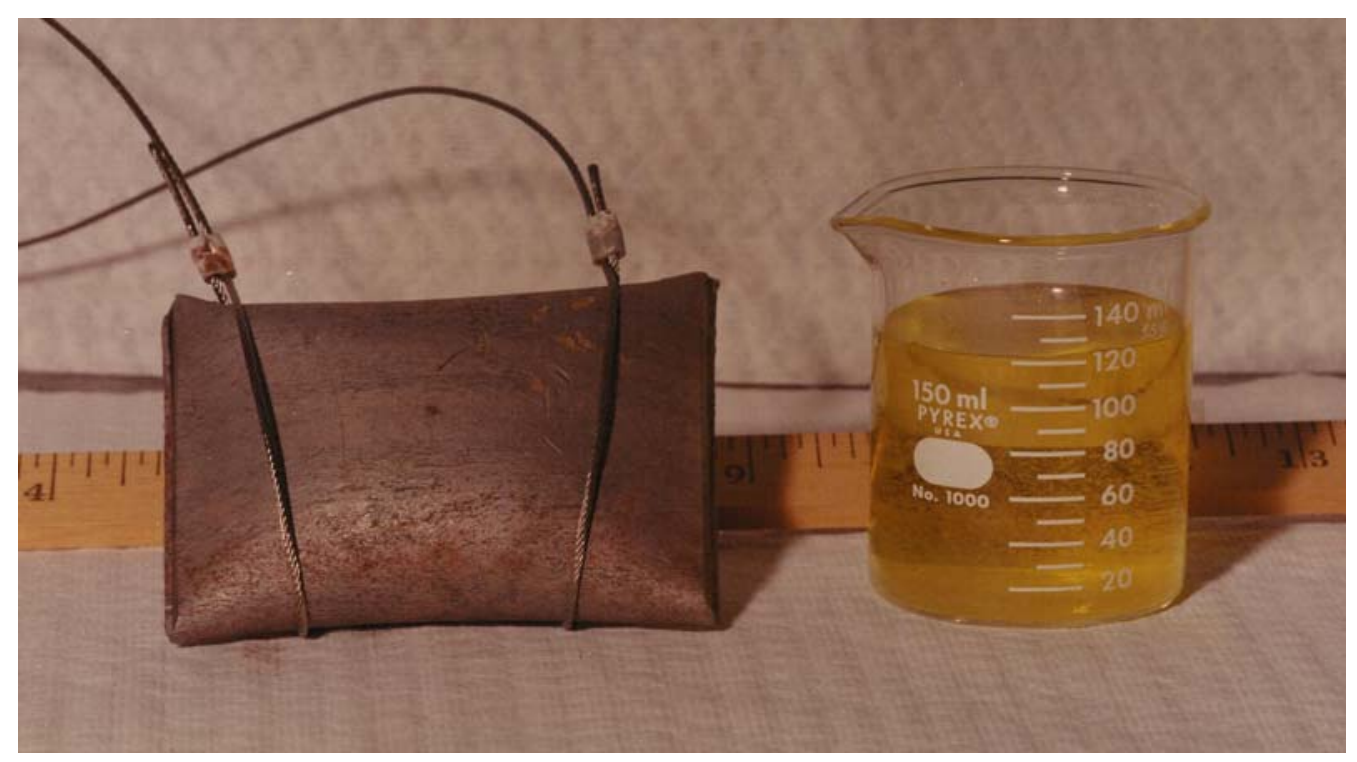

Figure 9 Appearance after Three Additional Treatments with 4 wt \% Oxalic Acid containing 0.5 Vol\% Hydrogen Peroxide

The dose rate at $30 \mathrm{~cm}$ had decreased from $\sim 7 \mathrm{rad} / \mathrm{h}$ to $\sim 0.1 \mathrm{rad} / \mathrm{h}$ beta-gamma. Decontaminating solution was yellow due to the $\mathrm{Fe}\left(\mathrm{C}_{2} \mathrm{O}_{4}\right)^{3-}$ complex ion which is soluble in acid. Based on weight loss, $\sim 1.1 \%$ of the coil had been dissolved. 




Figure 10 Close up of the Coil Sample after the Final Treatment with Oxalic Acid and Peroxide

Table 14 Summary of Oxalic Acid Solution and Oxalic Acid-Hydrogen Peroxide Solution Cleaning Performance Characteristics

\begin{tabular}{|c|c|c|}
\hline & Oxalic Acid Solution & $\begin{array}{l}\text { Oxalic Acid-Hydrogen } \\
\text { Peroxide Solution }\end{array}$ \\
\hline $\begin{array}{l}\text { Decrease in total } \\
\text { radioactivity }\end{array}$ & $65 \%$ after 6 treatments & $\begin{array}{c}90 \% \text { after } 3 \text { extra treatments } \\
\text { beyond the } 6 \text { treatments } \\
\text { with oxalic acid only }\end{array}$ \\
\hline $\begin{array}{l}\text { Decontamination constant } \\
\text { for decrease in total } \\
\text { radioactivity }\end{array}$ & $0.2 /$ test & $0.73 /$ test \\
\hline $\begin{array}{l}\text { Decontamination constant } \\
\text { for decrease in }{ }^{90} \mathrm{Sr}-\beta \\
\text { radioactivity }\end{array}$ & $0.14 /$ test & $0.87 /$ test \\
\hline $\begin{array}{l}\text { Decontamination constant } \\
\text { for decrease in }{ }^{238} \mathrm{Pu}-\alpha \\
\text { radioactivity }\end{array}$ & $0.077 /$ test & $0.85 /$ test \\
\hline $\begin{array}{l}\text { Coil weight loss through } \\
\text { dissolution }\end{array}$ & $0.13 \%$ after 6 treatments & $\begin{array}{c}1.4 \% \text { after } 3 \text { extra } \\
\text { treatments beyond the } 6 \\
\text { treatments with oxalic acid } \\
\text { only }\end{array}$ \\
\hline $\begin{array}{l}\text { Concentration of dissolved } \\
\text { iron in solution }\end{array}$ & $0.0036 \mathrm{M}$ & $0.058 \mathrm{M}$ \\
\hline Gas generation potential & none & yes \\
\hline
\end{tabular}


In summary, the tests revealed the following.

- Six treatments with 4 wt \% oxalic acid decreased the radioactivity on the coil by $65 \%$. Three additional treatments using 4 wt \% oxalic acid containing 0.5 vol. $\%$ hydrogen peroxide decreased the radioactivity further so that a total of $90 \%$ was removed.

- The decrease in activity followed a first-order rate law based on number of tests or treatments with a decontamination constant of 0.2 /test and $0.73 /$ test for oxalic acid and oxalic acid-hydrogen peroxide solutions respectively. This implies the oxalic acidhydrogen peroxide solution is 3.7 times more effective than the oxalic acid solution.

- The six oxalic acid solution treatments dissolved $0.13 \%$ of the coil sample while the three oxalic acid-hydrogen peroxide solution treatments dissolved $1.3 \%$ of the coil sample. In other words, a decrease in radioactivity of $90 \%$ for the oxalic acid-hydrogen peroxide solution corresponds to a $1.3 \%$ loss of the coil material through corrosion. However, the total average penetration into the coil from the surface was estimated to be $\sim 1$ mil assuming uniform corrosion. This depth was estimated from the concentration of dissolved iron in solution. The average iron concentrations in solution measured 0.0036 $\mathrm{M}$ and $0.058 \mathrm{M}$ for oxalic acid and oxalic acid-hydrogen peroxide solutions, respectively

- Potential exists for gas (carbon dioxide and oxygen) generation from the cleaning reactions. This would have to be investigated to determine if it is sufficient to pressurize the tank and increase the risk of a radioactive release.

It should be noted that the oxalic acid-hydrogen peroxide solution approach has not been demonstrated at the tank scale level. However, it does show promise for cleaning tank surfaces after most of the sludge has been removed from the tank.

\subsection{NITRIC ACID}

The use of nitric acid as a sludge dissolution agent has been investigated by Poirier and Fink. ${ }^{30}$ The results of a comparative study were previously described in Section 4.1. Figure 11 demonstrates that 4.0 M nitric acid performed comparably ( in terms of the amount of aluminum, iron, manganese, and silicon that dissolved from the sludge) to $0.5 \mathrm{M}$ oxalic acid, while $0.5 \mathrm{M}$ nitric acid was less effective. In their report, Poirier and Fink ${ }^{30}$ describe additional tests examining the use of nitric acid to dissolve sludges or solids.

The tests involved placing either simulated SRS High Level Waste Tank $40 \mathrm{H}$ sludge $(5 \mathrm{~g})$ and MST (5 g) or actual SRS High Level Waste Tank 8F sludge (1 g) and MST (1 g) in a beaker and adding $0.5,1.0,2.0$, and $4.0 \mathrm{M}$ nitric acid $(300 \mathrm{~mL}$ for simulated sludge and $60 \mathrm{~mL}$ for actual sludge). This was followed by magnetic stirring of the resulting slurry at a constant temperature (ambient or $40^{\circ} \mathrm{C}$ ), and periodically collecting filtered supernate samples for analysis of the sludge constituents (Al, Fe, Mn, Si, and Ti) using ICP-AES. Contact times of 1 and 8 hours were investigated. The tests did not involve multiple contacts (i.e., strikes). Table 10 in Section 4.1 provides the sludge compositions. Results from the tests are provided graphically in Figure 11. 


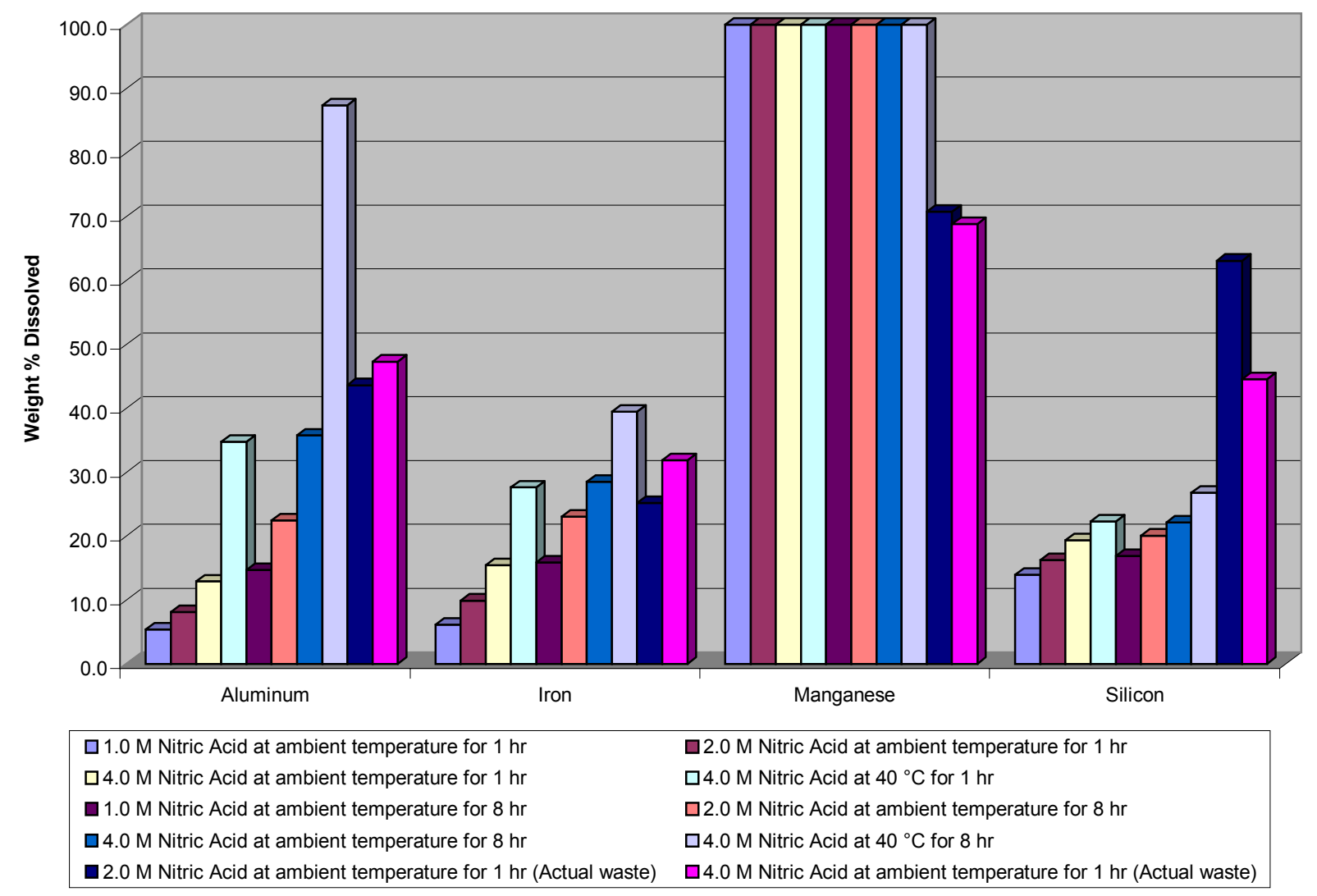

Figure 11 Effect of Nitric Acid Concentration, Temperature, and Contact Time on Dissolution of Sludge Species

The conclusions from the tests were identical to the oxalic acid conclusions reported by Poirier and Fink. ${ }^{30}$

- Increasing the nitric acid concentration enhanced sludge dissolution.

- Increasing the temperature increased the amount of sludge dissolved.

- Increasing the contact time increased the amount of sludge dissolved.

- For a $4 \mathrm{M}$ nitric acid solution, the effect of increasing temperature from ambient to $40{ }^{\circ} \mathrm{C}$ is roughly the same as increasing contact time from 1 to 8 hours.

- In general, nitric acid was very effective on manganese and less effective with respect to aluminum, iron and silicon.

- Increasing all three variables (concentration, temperature, and contact time) significantly increased the amount of aluminum dissolved.

- Actual Tank 8F sludge species (with the exception of manganese) were easier to dissolve than simulated sludge.

\subsection{OTHER ORGANIC CLEANING AGENTS}

In addition to the acids discussed in the preceding section, there are many documents in the literature that explore the use of other organic materials and acids as sludge dissolution agents. Among these are organic acids like formic and ascorbic acid, chelating and decontamination agents (e.g., EDTA and triethanolamine), and miscellaneous others (e.g., 1-hydroxyethane-1,1- 
diphosphonic acid). Included in this category would be the Russian work with Waste Caprolactam Product, known as WCP or "string waste". This is a complex mixture of organic acids that are a byproduct from nylon production. Introduction of a complex mixture of organic materials was deemed unsuitable for use at SRS. A review of its chemistry led to the recommendation to consider a mixture of oxalic and citric acid.

Of these other organic agents, the ones which provide the most information and experience are formic acid and ascorbic acid. Tests involving both formic and ascorbic acids (along with other organic agents) have been described in the work by Poirier and Fink ${ }^{30}$ and Bradley and Hill. ${ }^{31}$ Based upon their studies, oxalic acid and nitric acid appear more effective sludge dissolution agents than other organic materials. A review of formic acid is still warranted given our experience with its use in the DWPF. Introduction of organic-based chemicals in SRS facilities appears unlikely in the near future due to their poor performance in a few previous tests (relative to oxalic acid and nitric acid), possible adverse impacts on downstream processing (e.g., radiochemical separations in the Salt Waste Processing Facility), increased flammable gas generation and the insufficient quantity of data to evaluate their use. As such, only 1,1-hydroxy ethane-1,1-diphosphonic acid is briefly discussed and the remainder will not be addressed in this document other than to recommend that future investigations track their development. This substance is attractive given the low organic carbon content, the ease of decomposition and type of decomposition products.

\subsubsection{Formic Acid}

The investigation of formic acid as a cleaning agent for sludge heels from waste tanks stems from the vast experience garnered at SRS's DWPF. Its use at DWPF has been widely studied and documented. It is an efficient reagent for effecting neutralization of sludge and reduction of specific metals in the waste. However, the conditions employed at DWPF are severe (i.e., boiling) and its effectiveness in waste tank cleaning operations under milder temperatures remains largely untested. Bradley and $\mathrm{Hill}^{31}$ did conduct one scoping test with a mixture of formic and glycolic acid. In the test, the mixture dissolved approximately $50 \%$ of a sample of Tank 16H sludge (comparatively, oxalic acid under the same conditions dissolved approximately $70 \%$ of the sludge sample). A discussion of the chemistry of formic acid in the DWPF process is provided below.

\subsubsection{Formic Acid Experience with HLW Sludge in DWPF}

Formic acid is used extensively in the Defense Waste Processing Facility. Formic acid is the primary acid used to perform neutralization of sludge, reduction of mercury and manganese, and rheology adjustment. One of the primary reasons for using formic acid is for the reduction of mercury. HLW sludge contains mercury (II) oxide. Formic acid has been shown to be effective in reducing the oxide to elemental mercury (see Equation 1). ${ }^{37,38}$ In the DWPF, the mercury is then steam stripped from the sludge. In addition to mercury oxide reduction, several other equations have been proposed for the reactions that occur with HLW sludge during the addition of formic acid. ${ }^{39}$ Equations $2-7$ represent acid base reactions. Equation 6 also includes a redox reaction in which $\mathrm{Mn}(\mathrm{IV})$ reduces to $\mathrm{Mn}(\mathrm{II})$. 
$\mathrm{HgO}+\mathrm{HCOOH} \rightarrow \mathrm{Hg}+\mathrm{CO}_{2}+\mathrm{H}_{2} \mathrm{O}$

$\mathrm{NaOH}+\mathrm{HCOOH} \rightarrow \mathrm{HCOONa}+\mathrm{H}_{2} \mathrm{O}$

$\mathrm{KOH}+\mathrm{HCOOH} \rightarrow \mathrm{KCOOH}+\mathrm{H}_{2} \mathrm{O}$

$\mathrm{CaCO}_{3}+2 \mathrm{HCOOH} \rightarrow \mathrm{Ca}(\mathrm{COOH})_{2}+\mathrm{H}_{2} \mathrm{O}+\mathrm{CO}_{2}$

$\mathrm{Na}_{2} \mathrm{CO}_{3}+2 \mathrm{HCOOH} \rightarrow 2 \mathrm{NaCOOH}+\mathrm{CO}_{2}+\mathrm{H}_{2} \mathrm{O}$

$\mathrm{MnO}_{2}+3 \mathrm{HCOOH} \rightarrow \mathrm{Mn}^{++}+2 \mathrm{HCOO}^{-}+\mathrm{CO}_{2}+2 \mathrm{H}_{2} \mathrm{O}$

$\mathrm{Ni}(\mathrm{OH})_{2}+2 \mathrm{HCOOH} \rightarrow \mathrm{Ni}^{++}+2 \mathrm{HCOO}^{-}+2 \mathrm{H}_{2} \mathrm{O}$
Equation 1

Equation 2

Equation 3

Equation 4

Equation 5

Equation 6

Equation 7

The proposed reactions have been confirmed in both lab-scale and in engineering-scale demonstrations of the DWPF chemical processing cell process. Lab-scale demonstrations with actual waste and with sludge simulants have shown increased solubility of $\mathrm{Ca}, \mathrm{Mn}$, and $\mathrm{Na}$ after processing with formic acid. Depending on the amounts of acid used, solubility of these elements can range from $\sim 40$ to $100 \%{ }^{37,40,41} \mathrm{Ni}$ solubility has been shown to vary from test to test, but has been shown to become soluble with the addition of formic acid. ${ }^{37,40}$ It is believed that limited solubility of these components can be attributed to the formation of other compounds besides formate. ${ }^{38}$

The manganese reaction is believed to require temperatures near boiling to proceed and does not proceed to completion. ${ }^{38}$ This implies that Mn is present as other species in the sludge that will not reduce. The testing experience with actual sludge under DWPF formic acid addition conditions has resulted in very low solubility of most radionuclides with the exception of $\mathrm{Sr}$, which has shown relatively high solubility. ${ }^{37,40}$

Studies performed to support DWPF sludge acidification with formic acid have shown limited solubility of the major sludge components (i.e., Al and Fe). Al and Fe are typically insoluble at neutral or higher $\mathrm{pH}$. Typically, acid additions to adjust the sludge to $\mathrm{pH}$ of 4.5 to 5.5 have only resulted in $\mathrm{Al}$ and Fe solubility of $<10 \%$ and $<1 \%$, respectively. ${ }^{40,41}$ When the pH of HLW sludge has been adjusted to less than 4 , Al solubility slightly increases but is still relatively low. 40,41

The HLW sludge also contains anions such as nitrite that are destroyed in the DWPF. Proposed reactions with formic have also been written for this species (see Equations $8-10){ }^{39}$ 
The overall reactions can be summarized by the following equation:

$2 \mathrm{HCOOH}+3 \mathrm{NO}_{2}^{-} \rightarrow \mathrm{NO}_{3}^{-}+2 \mathrm{NO}+2 \mathrm{HCOO}^{-}+\mathrm{H}_{2} \mathrm{O}$

Equation 11

The reaction may also be summarized by the following equation:

$3 \mathrm{HCOOH}+2 \mathrm{NaNO}_{2} \rightarrow \mathrm{CO}_{2}+2 \mathrm{H}_{2} \mathrm{O}+2 \mathrm{NO}+2 \mathrm{NaCOOH}$

Equation 12

However, the extent of this reaction occurring during tank cleaning is not known. The DWPF reactions occur during boiling and through the use of condenser systems that allow the condensate to be recycled to the process vessel.

In the presence of noble metals, formic acid can be catalytically decomposed to hydrogen and carbon dioxide. ${ }^{37}$ This has been shown to occur at the elevated temperatures experienced in the DWPF chemical process cell and presents a safety concern for DWPF processing.

\subsubsection{1-Hydroxyethane-1,1-Diphosphonic Acid}

Researchers at Argonne National Laboratory studied the leaching behavior of actinides from simulants of tank waste sludges derived from Hanford's BiPO4, REDOX, and PUREX processes. $^{42}$ Sludge leaching methods in combination with contacts in series with $0.50 \mathrm{M} 1-$ Hydroxyethane-1,1-diphosphonic acid (HEDPA) were used to investigate the speciation of uranium and neptunium in solutions representative of proposed alkaline sludge washing liquors.

The results from sludge simulant leaching indicate that, while Am and $\mathrm{Pu}$ are generally not appreciably dissolved from the sludges into alkaline solutions in the absence of oxidants, Np and U can be mobilized during alkaline sludge washing. Leaching of sludges with acidic solutions and strong complexing agents indicate considerable association of all actinide ions with $\mathrm{Cr}, \mathrm{Fe}$, and Mn oxides in the sludge simulants. The document does not detail the efficiency at which the agent dissolves iron, aluminum, or manganese.

\subsection{CLEANING AGENT EVALUATION}

The objective of the Waste Tank Heel Removal Chemical Cleaning Team was to collect and evaluate information available on chemical-based methods for removing residual solids from the Savannah River Site's waste tanks. As part of this study, the team was requested to develop recommendations for chemical treatments to remove residual heels (primarily sludge). Ideally, 
one agent alone would be efficient at dissolving all residual tank heels and yet satisfy all safety and process concerns. No such chemical cleaning agent was found. The cleaning agents that were identified from the literature that were of most likely use at SRS were oxalic acid, a mixture of oxalic acid and citric acid, oxalic acid with hydrogen peroxide, nitric acid, formic acid, and organics (considered as a whole - this group would include triethanolamine, 1-hydroxyethane1,1-diphosphonic acid, EDTA, and many of the organic acids such as malonic and ascorbic acid). The Waste Tank Heel Removal Chemical Cleaning Team met with Washington Safety Management Systems (WSMS) personnel as well as DWPF and Tank Farm representatives to develop a criteria matrix for evaluating the various cleaning agents.

The evaluation matrix and assigned scores are shown in Table 16. A summary of the evaluation is provided in Table 15. The evaluation matrix consisted of five main criteria (slightly weighted) with multiple sub-criteria of equal weight. The five main criteria (with weighting shown in parentheses) were Technology (0.22), Operability and Logistics (0.18), Downstream Facility

Table 15 Composite Evaluation Matrix Scoring of the Various Cleaning Agents

\begin{tabular}{|c|c|c|c|c|c|c|c|}
\hline C rite rion & w eight & ع ع a a & $\begin{array}{l}\text { O x a lic t } \\
\text { P e ro xide }\end{array}$ & $\begin{array}{c}\text { O x a lic }+ \\
\text { C itric }\end{array}$ & $\mathrm{N}$ itric & Form ic & O rga n ics \\
\hline Technology & 0.22 & 2 & 2 & -1 & 3 & 0 & -5 \\
\hline $\begin{array}{c}\text { O pe ra b ility \& } \\
\text { L o g istics }\end{array}$ & 0.18 & 2 & 0 & 0 & 2 & 1 & -2 \\
\hline $\begin{array}{c}\text { Dow n stream } \\
\text { Im pacts }\end{array}$ & 0.2 & 0 & 0 & -2 & 3 & 2 & -2 \\
\hline A B Issues & 0.2 & 1 & 0 & 1 & -3 & 0 & -2 \\
\hline $\begin{array}{c}\text { Regul., P e m it., } \\
\& \text { IH Concems }\end{array}$ & 0.2 & 1 & 0 & -1 & -2 & 0 & -2 \\
\hline S core & & 1.20 & 0.44 & -0.62 & 0.62 & 0.58 & -2.66 \\
\hline
\end{tabular}


WSRC-TR-2003-00401

Table 16 Evaluation Matrix Scoring for Each Criterion

\begin{tabular}{|c|c|c|c|c|c|c|c|}
\hline Criterion & Defin ition & $\begin{array}{c}\text { O xa lic } \\
\text { Acid }\end{array}$ & $\begin{array}{c}\text { O xa lic }+ \\
\text { P e roxode }\end{array}$ & $\begin{array}{l}\text { O xa lic }+ \\
C \text { itric }\end{array}$ & $\mathrm{N}$ itric & Form ic & $\begin{array}{l}M \text { isc. - } \\
\mathrm{O} \text { rgan ics }\end{array}$ \\
\hline \multicolumn{8}{|l|}{ Technology } \\
\hline Tem perature & $\begin{array}{l}\text { D o es the te chnology re qu ire he a t to } \\
\text { b e e ffe ctive? }\end{array}$ & 0 & 0 & 0 & 1 & 0 & 0 \\
\hline $\begin{array}{r}\text { Energetic Com pound } \\
\text { Fom ation }\end{array}$ & $\begin{array}{l}\text { D oes the technology provide m a teria ls } \\
\text { capable ofprom oting energetic } \\
\text { m aterials? }\end{array}$ & 0 & 0 & 0 & 0 & 1 & 0 \\
\hline Foam in $g$ & $\begin{array}{l}\text { Does the technology lead to increased } \\
\text { fo am ing in any facility? }\end{array}$ & 1 & 1 & 1 & 0 & 1 & -1 \\
\hline Volum e & $\begin{array}{l}\text { Is the te chnolog y o ve rly sens itive to } \\
\text { vo lum e lim itations? }\end{array}$ & 0 & 0 & 0 & 1 & 0 & 0 \\
\hline Robustnes $s$ & $\begin{array}{l}\text { D oes the technology encom pass } \\
m \text { ultip le s ludge types/fo m s? }\end{array}$ & 0 & 0 & 0 & 1 & 0 & 0 \\
\hline $\begin{array}{r}\text { TC ( } \& \text { other } \\
\text { radionuclides) } \mathrm{F} \text { low path }\end{array}$ & $\begin{array}{l}\text { Does the technology im pactkey } \\
\text { radion uclides pos itive ly? }\end{array}$ & 0 & 1 & 0 & 1 & 0 & 0 \\
\hline $\begin{array}{r}\text { P rior s e / e ve lof } \\
\text { M a tu rity }\end{array}$ & $\begin{array}{l}\text { H as the technologybeen em ployed on } \\
\text { a large scale forcarbon steeltank? }\end{array}$ & 1 & -1 & -1 & -1 & -1 & -1 \\
\hline Le ve $l \circ \mathrm{fu} n d e r s \tan d$ in $g$ & $\begin{array}{l}\text { D o es su ffic ientknow le dge of } \\
\text { chem ica lbehaviorexis tfor the } \\
\text { te chnology? }\end{array}$ & 0 & 0 & 0 & 0 & 0 & -1 \\
\hline E ffe ctiveness & $\begin{array}{l}\text { H ow e ffe ctive is the technologyas a } \\
\text { dis solver? }\end{array}$ & 0 & 1 & 0 & 0 & -1 & -1 \\
\hline E ffe ctive nes s & $\begin{array}{l}\text { H o w e ffe ctive is the te chnolog y for } \\
\text { a ffe cting rheology? }\end{array}$ & 0 & 0 & 0 & 0 & 0 & 0 \\
\hline P rocess S im p licity & How com plex is the te chnology? & 0 & 0 & -1 & 0 & 0 & -1 \\
\hline
\end{tabular}


WSRC-TR-2003-00401

Table 16 Evaluation Matrix Scoring for Each Criterion (continued)

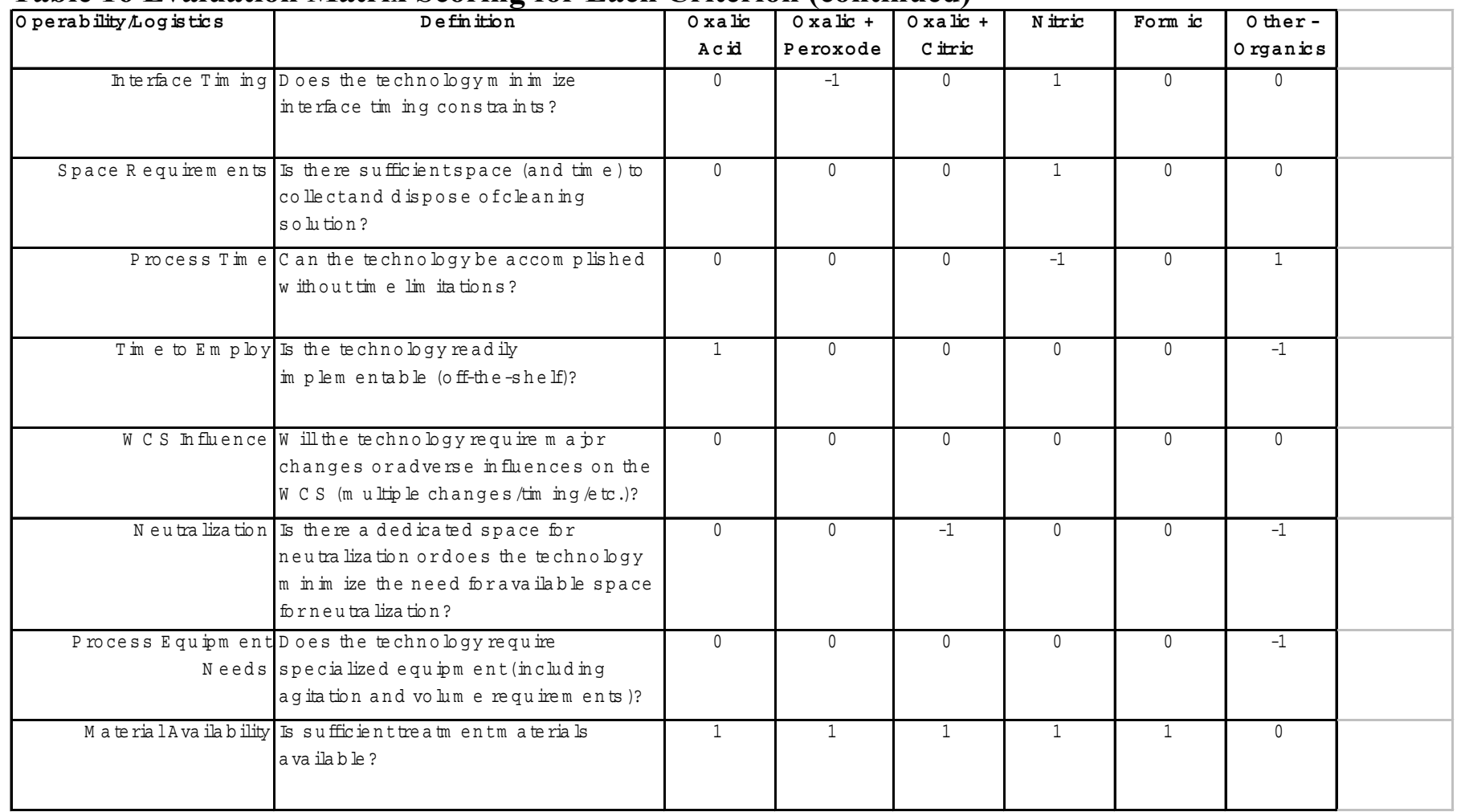


WSRC-TR-2003-00401

Table 16 Evaluation Matrix Scoring for Each Criterion (continued)

\begin{tabular}{|c|c|c|c|c|c|c|c|}
\hline $\begin{array}{l}\text { Dow nstream Facility } \\
\text { m pacts }\end{array}$ & Defin tition & $\begin{array}{l}\text { O xa lic } \\
\text { A cid }\end{array}$ & $\begin{array}{c}\text { Oxalic }+ \\
\text { Peroxode }\end{array}$ & $\begin{array}{c}\text { O xa lic }+ \\
\text { C itric }\end{array}$ & $\mathrm{N}$ itric & Form ic & $\begin{array}{c}\text { O ther- } \\
\text { Organics }\end{array}$ \\
\hline $\mathrm{DW} P \mathrm{P}$ & $\begin{array}{l}\text { D oes the technologym in im ize particle } \\
\text { s ize lim itations? }\end{array}$ & 0 & 0 & 0 & 0 & 0 & 0 \\
\hline & $\begin{array}{l}\text { D oes the technologym in im ize (le a ve } \\
\text { behind) quartz \& crys tabolite im pacts } \\
\text { on DW P F? }\end{array}$ & 0 & 0 & 0 & 0 & -1 & -1 \\
\hline & $\begin{array}{l}\text { Is } m \text { e ta loxa late fo } m \text { a tion proh ib itive } \\
\text { for the te chnology ( } \mathrm{g} \text { las } \mathrm{s} \text { quality)? }\end{array}$ & 0 & 0 & 0 & 0 & 0 & 0 \\
\hline & $\begin{array}{l}\text { W ill n e u tra liza tio n n e gative ly im pact } \\
\text { D W P F to u tilize m o re a cid? }\end{array}$ & 0 & 0 & 0 & 0 & 0 & 1 \\
\hline & $\begin{array}{l}\text { W ill the technology solubulize noble } \\
\text { m etals and cause problem s? }\end{array}$ & 0 & 0 & 0 & 0 & 0 & 0 \\
\hline TankFam & $\begin{array}{l}\text { Is neutra lization re quired and if so } \\
\text { w h a tim pactdoes it have on the } \\
\text { ne utra lizing facility? }\end{array}$ & 0 & 0 & 0 & 0 & 0 & 0 \\
\hline & $\begin{array}{l}\text { W here w ill ne utra lization of cle an ing } \\
\text { solution occur? }\end{array}$ & 0 & 0 & 0 & 0 & 0 & 0 \\
\hline & $\begin{array}{l}\text { A re the re increased (new) hydraulic } \\
\text { is sues in the transfer lines brought } \\
\text { aboutby the te chnology }\end{array}$ & 0 & 0 & 0 & 0 & 0 & 0 \\
\hline & S ludge B a tch P rep? & -1 & -1 & -1 & 0 & 0 & -1 \\
\hline E vaporator & $\begin{array}{l}\text { A re } A \text { l, } S \text { i, H g ofconcem (i.e., does the } \\
\text { te chnologyprom ote orexpose the } \\
\text { evaporatorto increased levels of } \\
\text { these m ateria ls)? }\end{array}$ & 0 & 0 & -1 & 0 & 0 & -1 \\
\hline & $\begin{array}{l}\text { D oes the technology provide m a te ria ls } \\
\text { capable ofprom oting energetic } \\
m \text { a teria ls in the evaporator? }\end{array}$ & 0 & 0 & 0 & 0 & 0 & 0 \\
\hline & $\begin{array}{l}\text { Is the evaporatorperfo m ance } \\
\text { im pacted (e.g., oxa lates present?) }\end{array}$ & 0 & 0 & 0 & 1 & 1 & 0 \\
\hline & $\begin{array}{l}\text { D oes the technologyprom ote scale } \\
\text { fo m a tion in the evaporator? }\end{array}$ & 0 & 0 & 0 & 1 & 1 & 0 \\
\hline S P P & $\begin{array}{l}\text { W ill s tre am from evaporatorbottom s } \\
\text { negative ly im pactSP P (s o lvent } \\
\text { extraction in fluence)? }\end{array}$ & 1 & 1 & 0 & 1 & 1 & 0 \\
\hline
\end{tabular}

\begin{tabular}{|c|c|c|c|c|c|c|c|}
\hline A B Im pacts & Defin tition & $\begin{array}{c}\text { O xa lic } \\
\text { Acid }\end{array}$ & $\begin{array}{c}\text { O xa lic }+ \\
\text { P e roxode }\end{array}$ & $\begin{array}{l}\text { O xa lic }+ \\
\text { C itric }\end{array}$ & $\mathrm{N}$ itric & Form ic & $\begin{array}{l}\text { O ther- } \\
\text { O rganics }\end{array}$ \\
\hline F la m m ab ility & $\begin{array}{l}\text { Does the technology lead to } \\
\text { flam } m \text { ab ility is sues for any facility? }\end{array}$ & 1 & 1 & 1 & 1 & 1 & -1 \\
\hline G as G eneration & $\begin{array}{l}\text { Is hydrogen orotherham fulgases } \\
\text { ge ne rated in any fa cility? }\end{array}$ & 0 & 0 & 0 & -1 & 0 & -1 \\
\hline C ritic a lity & $\begin{array}{l}\text { D oes the te chnology le ad to critica lility } \\
\text { concems for any facility? }\end{array}$ & -1 & -1 & -1 & -1 & -1 & -1 \\
\hline Corros ion & $\begin{array}{l}\text { D oes the technology result in } \\
\text { corros ion concerns forany facility? }\end{array}$ & 1 & 0 & 1 & -1 & 0 & 1 \\
\hline Tem perature & $\begin{array}{l}\text { D oes the technology re } s u \text { lt in a } \\
\text { s ign ificantexothe m ic reaction? }\end{array}$ & 0 & 0 & 0 & -1 & 0 & 0 \\
\hline Tem perature & $\begin{array}{l}\text { If the te chnology requires heat, w ill } \\
\text { the re be sign ificantdetrim enta le ffe ct } \\
\text { on exposed in frastructure le qu ipm ent? }\end{array}$ & 0 & 0 & 0 & 0 & 0 & 0 \\
\hline
\end{tabular}


Table 16 Evaluation Matrix Scoring for Each Criterion (continued)

\begin{tabular}{|c|c|c|c|c|c|c|c|}
\hline Regu la tory $/ P$ erm itting $/ \mathbb{H}$ & De fin tition & $\begin{array}{l}\text { Oxa lic } \\
\text { Acid }\end{array}$ & $\begin{array}{c}\text { Oxalic }+ \\
\text { Pe roxode }\end{array}$ & $\begin{array}{c}\text { xa lic }+ \\
\text { C itric }\end{array}$ & N itric & Form ic & \begin{tabular}{|c|}
0 ther - \\
0 rganics
\end{tabular} \\
\hline C losure Is sues & $\begin{array}{l}\text { D oes the technology im pacttank } \\
\text { closure org routing (i.e., is closure } \\
\text { negative ly im pacted)? }\end{array}$ & 0 & $\overline{0}$ & 0 & 0 & 0 & 0 \\
\hline P e m iting & A re the re pem iting lim itations? & 0 & 0 & 0 & 0 & 0 & 0 \\
\hline R e gu la to ry $C$ oncems & $\begin{array}{l}\text { A re the re re gu la to ry ba rriers and } \\
\text { concems? }\end{array}$ & 0 & 0 & 0 & -1 & 0 & 0 \\
\hline P o litic a l A c ce p ta b ility & $\begin{array}{l}\text { Is the te chno lo } g \text { y } p o \text { litica lly acceptab le } \\
(e . g ., \text { le ve } l o f \text { rem ovals u ffic ie } n t) \text { ? }\end{array}$ & 0 & $\overline{0}$ & $\overline{0}$ & 0 & 0 & -1 \\
\hline H a zardous Chem icals & $\begin{array}{l}\text { Does the technology require the } \\
\text { use/disposalofhazardous m a te ria ls? }\end{array}$ & 0 & 0 & 0 & 0 & 0 & 0 \\
\hline R C R A M e ta ls & $\begin{array}{l}\text { W ill the technology solubulize R C RA } \\
m \text { e ta ls and result in additional } \\
d \text { isposalproblems? }\end{array}$ & 0 & 0 & -1 & 0 & 0 & -1 \\
\hline S a fety & $\begin{array}{l}\text { D oes the technology lead to increased } \\
\text { H R adC on concems (Including } \\
\text { organom ercury)? }\end{array}$ & 1 & $\overline{0}$ & 0 & -1 & $\overline{0}$ & 0 \\
\hline
\end{tabular}

Impacts (0.20), AB Issues (0.20), and Regulatory, Permitting, and Industrial Hygiene Concerns (0.20). The Waste Tank Heel Removal Chemical Cleaning Team then used the matrix to evaluate the cleaning agents. The evaluation consisted of assigning one of three values $(+1=$ more favorable, $0=$ neutral, $-1=$ less favorable) to each agent for each sub-criteria. These were then summed up within each main criterion and multiplied by the weighting factor. It should be noted that this evaluation was subjective (i.e., the scores represented the consensus opinion of the members in attendance and are not based upon a quantitative comparative study).

The results of the evaluation conclusively support oxalic acid as the cleaning agent of choice for the immediate future. Its score was nearly double the next closest cleaning agent. Nitric acid, formic acid, and oxalic acid with hydrogen peroxide were all closely grouped as the next best choice. The mixture of oxalic acid and citric acid was viewed negatively (mostly due to the fact that it performed less well than oxalic acid and the presence of citrate could lead to problems within DWPF). Organics were viewed even more negatively. The addition of organic materials to the HLW system leads to a number of concerns such as safety impacts, equipment limitations, $\mathrm{AB}$ issues, and ultimately the technology is rather young and little experience is available. The application of organic cleaning agents in the near future is highly suspect. At best, organics should continue to be researched for use in the next 2 or 3 years. 


\subsection{SLUDGE COMPOUNDS AND PROCESS CHEMISTRY}

The following section attempts to address some of the factors that are of concern to the dissolution of sludge. These include the type of sludge, the components in the sludge, added materials (like zeolite), waste tank conditions (e.g., temperature), and time. A brief discussion of sludge formation and the background processes responsible for it is provided. ${ }^{43}$

\subsection{SLUDGE FORMATION}

There are five different waste types resulting from major separation processes conducted in 221F \& H facilities: PUREX, HM, Frames, High Heat and Low Heat. The PUREX, HM, and Frames processes recovered uranium, neptunium, and plutonium. PUREX processing occurred primarily in F-Canyon, while HM and Frames processes were conducted in H-Canyon. The terms High Heat and Low Heat waste result from the amount of fission products the waste contains and the heat it generates.

Acidic canyon waste is neutralized in a canyon waste tank prior to sending it to the HLW tanks. Prior to its neutralization, the acidic waste is analyzed to verify that an adequate concentration of neutron absorbers are present. Specific elements that are neutron absorbers include manganese, iron, nickel, and mercury. If necessary, additional neutron poisons (e.g., ferrous sulfamate or depleted uranyl nitrate) are added. Upon receipt in the Tank Farm, the neutralized waste forms two phases, settled solids, called sludge, and supernate, which contains dissolved salts. Principal components (and their sources) of the two phases are provided in Table $17 .{ }^{43}$

Table 17 Source of Salt and Sludge Components ${ }^{43}$

\begin{tabular}{|c|c|c|c|}
\hline \multirow[b]{2}{*}{ Com ponent } & \multirow[b]{2}{*}{ Phase } & \multirow{2}{*}{\multicolumn{2}{|c|}{ Source }} \\
\hline & & & \\
\hline \multirow[t]{2}{*}{$\mathrm{N}$ aA $1 \mathrm{O}_{2}$} & $10 \div \operatorname{sludge}$ & A lum in um & Componentof reactor fueland targets \\
\hline & $90 \div$ salt & A lum in um $\mathrm{N}$ itrate & $\begin{array}{l}\text { R equired to prevent fluo ride io } n, \text { w hen used, from } \\
\text { co rroding sta in les s steelequ ipm ent }\end{array}$ \\
\hline \multirow[t]{2}{*}{$\mathrm{NaNO}$} & S alt & $\mathrm{N}$ itric A cid & Salting agent for solvent extraction \\
\hline & & Sod ium $\mathrm{N}$ itrate & $\begin{array}{c}\text { U sed to suppress hydrogen evolution in jacket rem oval } \\
\text { from reactortargets }\end{array}$ \\
\hline $\mathrm{N}_{2} \mathrm{CO}_{3}$ & & Sodium Carbonate & D econtam in ation agent for so lvent extraction solvent \\
\hline $\mathrm{N} \mathrm{a}_{2} \mathrm{SO}_{4}$ & S alt & F errous Su lfam ate & Reductant for so lvent extraction \\
\hline $\mathrm{Fe}(\mathrm{OH})_{3}$ & S ludge & F errous Su lfam ate & Reductant for solvent extraction \\
\hline $\mathrm{N} \mathrm{aOH}$ & S alt & Sodium $\mathrm{H}$ y d roxide & A dded to preventcorrosion of H LW tanks \\
\hline $\mathrm{N} \mathrm{i}(\mathrm{OH})_{2}$ & Sludge & $\mathrm{N}$ ickel & Componentof reactortargets \\
\hline $\mathrm{MnO} 2$ & S ludge & M anganous $\mathrm{N}$ itrate & $\begin{array}{l}\text { U sed to produce M no } 2 \text { precip itate in } \mathrm{H} \text { ead End } \\
\text { decontam in ation strike }\end{array}$ \\
\hline $\mathrm{HgO}$ & Sludge & M ercury & Catalyst fordissolv ing a lum in um in fueland targets \\
\hline
\end{tabular}


Supernate contains primarily sodium aluminate $\left(\mathrm{NaAlO}_{2}\right)$, sodium nitrate $\left(\mathrm{NaNO}_{3}\right)$, sodium sulfate $\left(\mathrm{Na}_{2} \mathrm{SO}_{4}\right)$, and sodium hydroxide $(\mathrm{NaOH})$. This supernate is concentrated in HLW evaporators and stored as concentrated supernate or crystalline salt in the HLW tanks. Its high degree of radioactivity stems primarily from the presence of soluble cesium-137. The sludge that forms from neutralization of the acidic canyon waste settles to bottom of the HLW tanks. It contains most of the highly radioactive fission products (excluding ${ }^{137} \mathrm{Cs}$ ). In addition to the fission products, sludge contains many oxides and hydroxides of the neutron poisons. These would include, ferric hydroxide $\left(\mathrm{Fe}(\mathrm{OH})_{3}\right)$, nickel hydroxide $\left(\mathrm{Ni}(\mathrm{OH})_{2}\right)$, manganese dioxide $\left(\mathrm{MnO}_{2}\right)$, mercury oxide $(\mathrm{HgO})$, and about $10 \%$ of the sodium aluminate contained in the waste.

\subsection{THE MECHANICAL STRENGTH OF AGGREGATES}

During settling of wet sludge, the interstitial liquid between the sludge grains is squeezed out of the sludge leaving a residual liquid that bridges the sludge grains. The residual liquid binds the granules together by a combination of capillary pressure, surface tension and viscous forces until more permanent bonds are made by subsequent drying or higher overhead pressure (both increase the bond strengthening rate).

The cohesive strength of the aggregate is the ceramic bond (derived from mineralization reactions) or bridge between aggregates. To suspend the sludge, the force of the pump suction and water jet from the slurry pump must be larger than the ceramic bond or bridging force of the aggregate. The strength of an aggregate is given by the following equation. ${ }^{44}$

$$
\sigma=\frac{F_{\text {bridgebond }} \times(1-\text { porosity })}{d_{\text {particle }}^{2} \times 2 \times \text { porosity }^{3 / 2}}
$$

Equation 13

where $F_{\text {bridgebond }}$ is the force of the bridge holding the aggregates together, and $\mathrm{d}_{\text {particle }}$ is the diameter of the particle.

In the case of a wet sludge, the force between two wet aggregates is due to surface tension and curvature of the liquid bridge. In the case of dried sludge, the force of the bridge holding the granules together is the interfacial strength between the granules and the bridge. The interfacial strength of the bridge-granule bond is usually $1 / 4$ the compressive strength of the granules. ${ }^{44}$ For example, the compressive strength of gibbsite is around $300 \mathrm{~N} / \mathrm{mm}^{45}$ Assuming spherical gibbsite grains of $3 \mathrm{~mm}$ diameter that are held together by gibbsite bridges (bonds), the tensile force holding the granules together is approximately $563 \mathrm{kN}$. The free water content of wet and settled sludge ranged from 20 to $25 \mathrm{wt} \%{ }^{46}$ The density of wet sludge ranges from 1.15 to 1.2 $\mathrm{g} / \mathrm{mL}$, if the solid phase of the sludge is made of boehmite or hematite. Therefore, the porosity of wet sludge is calculated to be around 0.9 .

The force of the jet emanating from the slurry pump must overcome the cohesive strength of the sludge aggregates. The amount of energy delivered by a slurry pump can be calculated using the following equations. ${ }^{47}$ 
$E=\frac{1}{2} m v^{2}$

Equation 14

and

$v_{\text {at somedistance y }}=6.2 \times v_{\text {orifice }} \times\left(\frac{\text { orifice diameter }}{\mathrm{y}}\right)$

Equation 15

where $v$ is the velocity of the inhibited water stream and $y$ is the distance away from the orifice (in feet). Given that, force of the jet is defined as:

Force of the jet $=$ density $\times$ Flow Rate $\times$ velocity $\times \sin \theta$

Equation 16

where $\theta$ is the angle between the jet and the sludge surface.

\subsection{REACTION CHEMISTRY}

The reactions of oxalic acid with sludge are dependent upon the chemical species of the various elements that make up the sludge (and therefore vary by sludge type). Reactions for dissolution of some of these substances with oxalic acid are shown below.

$2 \mathrm{AlOOH}+3 \mathrm{H}_{2} \mathrm{C}_{2} \mathrm{O}_{4} \rightarrow \mathrm{Al}_{2}\left(\mathrm{C}_{2} \mathrm{O}_{4}\right)_{3}+4 \mathrm{H}_{2} \mathrm{O}\left(\mathrm{Al}^{+3}\right.$ also appears in solution $)$

Equation 17

$2 \mathrm{Al}(\mathrm{OH})_{3}+3 \mathrm{H}_{2} \mathrm{C}_{2} \mathrm{O}_{4} \rightarrow \mathrm{Al}_{2}\left(\mathrm{C}_{2} \mathrm{O}_{4}\right)_{3}+6 \mathrm{H}_{2} \mathrm{O}$

Equation 18

$\mathrm{FeO}+\mathrm{H} 2 \mathrm{C} 2 \mathrm{O} 4 \rightarrow \mathrm{FeC} 2 \mathrm{O} 4+\mathrm{H} 2 \mathrm{O}$

Equation 19

$\mathrm{Fe}(\mathrm{OH})_{3}+3 / 2 \mathrm{H}_{2} \mathrm{C}_{2} \mathrm{O}_{4} \rightarrow \mathrm{FeC}_{2} \mathrm{O}_{4}+\mathrm{CO}_{2}+3 \mathrm{H}_{2} \mathrm{O}$ (Ferrihydrite Reaction)

Equation 20

$\mathrm{FeOOH}+3 / 2 \mathrm{H}_{2} \mathrm{C}_{2} \mathrm{O}_{4} \rightarrow \mathrm{FeC}_{2} \mathrm{O}_{4}+\mathrm{CO}_{2}+2 \mathrm{H}_{2} \mathrm{O}$ (goethite reaction)

Equation 21

$\mathrm{Fe}_{2} \mathrm{O}_{3}+3 \mathrm{H}_{2} \mathrm{C}_{2} \mathrm{O}_{4} \rightarrow \mathrm{Fe}_{2}\left(\mathrm{C}_{2} \mathrm{O}_{4}\right)_{3}+\mathrm{H}_{2} \mathrm{O}$ (Hematite reaction)

Equation 22

$\mathrm{Fe}_{3} \mathrm{O}_{4}+4 \mathrm{H}_{2} \mathrm{C}_{2} \mathrm{O}_{4} \rightarrow \mathrm{Fe}_{2}\left(\mathrm{C}_{2} \mathrm{O}_{4}\right)_{3}+\mathrm{FeC}_{2} \mathrm{O}_{4}+4 \mathrm{H}_{2} \mathrm{O}$ (magnetite reaction)

Equation 23

$\mathrm{Fe}_{2} \mathrm{O}_{3}+2 \mathrm{H}_{2} \mathrm{C}_{2} \mathrm{O}_{4} \rightarrow 2 \mathrm{Fe}\left(\mathrm{C}_{2} \mathrm{O}_{4}\right)+2 \mathrm{H}_{2} \mathrm{O}+\mathrm{O}_{2}$ (complexing)

Equation 24

$\mathrm{MnO}+\mathrm{H}_{2} \mathrm{C}_{2} \mathrm{O}_{4} \rightarrow \mathrm{Mn}\left(\mathrm{C}_{2} \mathrm{O}_{4}\right)+1 / 2 \mathrm{O}_{2}$ (complexing)

Equation 25 
WSRC-TR-2003-00401

$\mathrm{Mn}_{2} \mathrm{O}_{3}+2 \mathrm{H}_{2} \mathrm{C}_{2} \mathrm{O}_{4} \rightarrow 2 \mathrm{Mn}\left(\mathrm{C}_{2} \mathrm{O}_{4}\right)+2 \mathrm{H}_{2} \mathrm{O}+1 / 2 \mathrm{O}_{2}$

Equation 26

$\mathrm{Mn}_{3} \mathrm{O}_{4}+3 \mathrm{H}_{2} \mathrm{C}_{2} \mathrm{O}_{4} \rightarrow 3 \mathrm{Mn}\left(\mathrm{C}_{2} \mathrm{O}_{4}\right)+3 \mathrm{H}_{2} \mathrm{O}+1 / 2 \mathrm{O}_{2}$

Equation 27

Reactions of the species with nitric acid are provided below.

$\mathrm{AlOOH}+3 \mathrm{HNO}_{3} \rightarrow \mathrm{Al}^{3+}+3 \mathrm{NO}_{3}^{-}+2 \mathrm{H}_{2} \mathrm{O}$

Equation 28

$\mathrm{Al}(\mathrm{OH})_{3}+3 \mathrm{HNO}_{3} \rightarrow \mathrm{Al}^{3+}+3 \mathrm{NO}_{3}^{-}+3 \mathrm{H}_{2} \mathrm{O}$

Equation 29

$\mathrm{Fe}_{2} \mathrm{O}_{3}+6 \mathrm{HNO}_{3} \rightarrow 2 \mathrm{Fe}^{3+}+6 \mathrm{NO}_{3}^{-}+3 \mathrm{H}_{2} \mathrm{O}$ (complexing)

Equation 30

$\mathrm{FeO}+2 \mathrm{HNO}_{3} \rightarrow \mathrm{Fe}^{2+}+2 \mathrm{NO}_{3}{ }^{-}+\mathrm{H}_{2} \mathrm{O}$

Equation 31

$\mathrm{Fe}(\mathrm{OH})_{3}+3 \mathrm{HNO}_{3} \rightarrow \mathrm{Fe}^{3+}+3 \mathrm{NO}_{3}^{-}+3 \mathrm{H}_{2} \mathrm{O}$ (Ferrihydrite Reaction)

Equation 32

$\mathrm{FeOOH}+3 \mathrm{HNO}_{3} \rightarrow \mathrm{Fe}^{3+}+3 \mathrm{NO}_{3}^{-}+2 \mathrm{H}_{2} \mathrm{O}$ (goethite reaction)

Equation 33

$\mathrm{Fe}_{2} \mathrm{O}_{3}+6 \mathrm{HNO}_{3} \rightarrow 2 \mathrm{Fe}^{3+}+6 \mathrm{NO}_{3}^{-}+6 \mathrm{H}_{2} \mathrm{O}$ (Hematite reaction)

Equation 34

$\mathrm{Fe}_{3} \mathrm{O}_{4}+8 \mathrm{HNO}_{3} \rightarrow 2 \mathrm{Fe}^{3+}+\mathrm{Fe}^{2+}+8 \mathrm{NO}_{3}^{-}+4 \mathrm{H}_{2} \mathrm{O}$ (magnetite reaction)

Equation 35

$\mathrm{Mn}_{2} \mathrm{O}_{3}+6 \mathrm{HNO}_{3} \rightarrow 2 \mathrm{Mn}^{3+}+6 \mathrm{NO}_{3}^{-}+3 \mathrm{H}_{2} \mathrm{O}$

Equation 36

$\mathrm{Mn}_{3} \mathrm{O}_{4}+8 \mathrm{HNO}_{3} \rightarrow 2 \mathrm{Mn}^{3+}+\mathrm{Mn}^{2+}+8 \mathrm{NO}_{3}{ }^{-}+4 \mathrm{H}_{2} \mathrm{O}$

Equation 37

Given these general reactions, the amount of oxalic acid needed to leach some components out of $1 \mathrm{~kg}$ of sludge is given in Table 18 and Table 19. The actual amount of oxalic needed must also include side reactions between oxalic acid, sodium nitrite, and sodium carbonate (see Equations 38 and 39).

Table 18 Amount of Oxalic Acid Needed to Leach Various Components Out of $1 \mathrm{~kg}$ of HM Sludge

\begin{tabular}{|c|c|c|}
\hline Substance & Grams & Moles of Oxalic acid \\
\hline $\mathrm{Al}(\mathrm{OH})_{3}$ & 330 & 6.3 \\
\hline $\mathrm{Fe}_{2} \mathrm{O}_{3}$ & 41 & 0.5 \\
\hline $\mathrm{MnO}$ & 19 & 0.3 \\
\hline $\mathrm{NiO}$ & 5 & 0.1 \\
\hline $\mathrm{HM}$ sludge & 1000 & 7.2 \\
\hline
\end{tabular}


WSRC-TR-2003-00401

Table 19 Amount of Oxalic Acid Needed to Leach Various Components Out of $1 \mathrm{~kg}$ of PUREX Sludge

\begin{tabular}{|c|c|c|}
\hline Substance & Grams & Moles of Oxalic acid \\
\hline $\mathrm{Al}(\mathrm{OH})_{3}$ & 3 & 0.06 \\
\hline $\mathrm{Fe}_{2} \mathrm{O}_{3}$ & 19 & 0.24 \\
\hline $\mathrm{MnO}$ & 3.7 & 0.05 \\
\hline $\mathrm{NiO}$ & 3.8 & 0.05 \\
\hline PUREX sludge & 1000 & 0.4 \\
\hline
\end{tabular}

The addition of oxalic acid will also react with nitrite (in the presence of either iron or manganese) to generate $\mathrm{NOx}$ and $\mathrm{CO}$ gases as follows.

$\mathrm{H}_{2} \mathrm{C}_{2} \mathrm{O}_{4}+\mathrm{NaNO}_{2}+1 / 2 \mathrm{O}_{2} \rightarrow \mathrm{NO}+\mathrm{NaNO}_{3}+2 \mathrm{CO}+\mathrm{H}_{2} \mathrm{O}$

Equation 38

Oxalic acid and carbonates can also react as shown in Equation 39 to release carbon dioxide.

$\mathrm{H}_{2} \mathrm{C}_{2} \mathrm{O}_{4}+\mathrm{Na}_{2} \mathrm{CO}_{3} \rightarrow \mathrm{Na}_{2} \mathrm{C}_{2} \mathrm{O}_{4}$ (soluble) $+\mathrm{CO}_{2}+\mathrm{H}_{2} \mathrm{O}$

Equation 39

\subsection{HEAT OF NEUTRALIZATION OF OXALIC ACID}

The heat generated when acid and base are added together derived from two sources: 1) the heat of dilution and 2) the heat of neutralization. The heat of neutralization (ignoring heat of dilution) has been reported at $31 \mathrm{kcal} / \mathrm{mole}^{48}$ The heat of neutralization (while considering the heat of dilution) has been reported at $13 \mathrm{kcal} / \mathrm{mole}^{49}$

Temperature rise experiments were conducted in support of the Tank $16 \mathrm{H}$ sludge dissolution program. ${ }^{48}$ The experiments used $300 \mathrm{~g}$ of $8 \mathrm{wt} \%$ oxalic acid heated to various temperatures $\left(22,40\right.$, and $\left.80^{\circ} \mathrm{C}\right)$. Sodium hydroxide was added at two different concentrations $(20 \mathrm{wt} \%$ and $50 \mathrm{wt} \%$ ) and the temperature change recorded. The $\mathrm{NaOH}$ was dumped into the oxalic acid since the pump tank addition rate was determined to be $\geq 1.3 \mathrm{~L} / \mathrm{s}$. A temperature rise of $15{ }^{\circ} \mathrm{C}$ was observed for when $50 \mathrm{wt} \% \mathrm{NaOH}$ was added to oxalic acid at $80{ }^{\circ} \mathrm{C}$. The maximum rise observed was $25{ }^{\circ} \mathrm{C}$ when $50 \mathrm{wt} \% \mathrm{NaOH}$ was added to the oxalic acid at $22{ }^{\circ} \mathrm{C}$. Approximately $80 \%$ of the theoretical quantity of sodium oxalate precipitated within a minute of adding the $\mathrm{NaOH}$.

\subsection{OXALIC ACID SOLUBILITY}

Oxalic acid has a limited solubility in water. Table 20 provides the solubility of oxalic acid in water a function of temperature. ${ }^{50}$ Note that the temperature must be $15{ }^{\circ} \mathrm{C}$ or higher to maintain a soluble oxalic acid concentration of $8 \mathrm{wt} \%$. 
Table 20 Oxalic Acid Solubility in Water as a Function of Temperature

\begin{tabular}{|c|c|}
\hline $\begin{array}{c}\text { Temperature } \\
\left({ }^{\circ} \mathbf{C}\right)\end{array}$ & $\begin{array}{c}\text { Oxalic Acid } \\
\text { Concentration } \\
(\mathbf{w t} \%)\end{array}$ \\
\hline 5 & 4.2 \\
\hline 10 & 6 \\
\hline 15 & 8 \\
\hline 20 & 10 \\
\hline 25 & 12 \\
\hline 30 & 15.5 \\
\hline 35 & 18 \\
\hline 40 & 23 \\
\hline 45 & 28 \\
\hline 50 & 36 \\
\hline 55 & 47 \\
\hline 60 & 61 \\
\hline
\end{tabular}

\subsection{CLEANING AGENT EFFECTS ON SLUDGE COMPONENTS}

One of the current missions at SRS is the emptying of high level waste tanks. This requires the retrieval of residual sludge (the heel remaining after bulk sludge removal) from several sludge tanks. The current strategy includes slurrying the sludge with inhibited water followed by chemical removal of the final residual heel.

The current understanding of the chemical compounds in heels includes aluminosilicates (cancrinite and sodalite), hematite, boehmite and amorphous manganese oxide. The exact chemical composition of the heel varies from tank to tank. To support a chemical removal process, an understanding of the intrinsic dissolution behavior of inorganic oxides in the various cleaning solutions is required.

The chemical cleaning efficiency of inorganic oxides depends significantly on the cleaning agent and the type of oxide. HLW sludges are a complex mixture comprised mainly of inorganic hydroxides and hydrous oxides that includes pure and mixed chemical phases and aggregates of the pure and mixed phases. Storage conditions and time can serve to modify both the chemical phase and the morphology and surface structure of the individual sludge particles. These factors lead to non-ideal dissolution behavior of the sludge components compared to pure oxide phases. Nonetheless, knowledge of the intrinsic dissolution behavior of the pure oxide components in the sludge provides a tool for the design and selection of chemical agents.

A review of the literature revealed four important processes (surface controlled dissolution) by which inorganic oxides and hydroxides dissolve. ${ }^{51}$ A list of these dissolution processes and a typical reaction example for each follows.

- Proton (hydrogen ion) assisted dissolution with acids (e.g., nitric acid)

$$
\mathrm{Fe}_{2} \mathrm{O}_{3} \text { (Hematite) }+6 \mathrm{H}^{+} \rightarrow 2 \mathrm{Fe}^{3+}+3 \mathrm{H}_{2} \mathrm{O}
$$


- Reductive agents (e.g., sodium thiosulfite)

$$
\mathrm{Fe}_{2} \mathrm{O}_{3}+\mathrm{Na}_{2} \mathrm{~S}_{2} \mathrm{O}_{4}+4 \mathrm{H}^{+} \rightarrow 2 \mathrm{Fe}^{2+}+2 \mathrm{Na}^{+}+2 \mathrm{HSO}_{3}{ }^{-}+\mathrm{H}_{2} \mathrm{O}
$$

Equation 41

- Oxidative agents (e.g., hydrogen peroxide)

$$
2 \mathrm{FeO}+\mathrm{H}_{2} \mathrm{O}_{2} \rightarrow \mathrm{Fe}_{2} \mathrm{O}_{3}+\mathrm{H}_{2} \mathrm{O}
$$

- Ligands and complexing agents (organic like citric and oxalic acid and inorganic like phosphates)

$$
\mathrm{Fe}_{2} \mathrm{O}_{3}+3 \mathrm{C}_{2} \mathrm{O}_{2}(\mathrm{OH})_{2} \rightarrow \mathrm{Fe}_{2}\left(\mathrm{C}_{2} \mathrm{O}_{4}\right)_{3}+3 \mathrm{H}_{2} \mathrm{O}
$$

Equation 43

The dissolution mechanism for a given solvent may also include a combination of the processes above. For example, oxalic acid interaction with oxides includes proton and ligand assisted oxide dissolution.

The literature survey also revealed that the dissolution efficiency (efficiency includes speed and extent of oxide dissolution) of a solvent significantly depends on the type of oxide or hydroxide compound it encounters. The general trend in the chemical dissolution of the different oxide compounds for a given cleaning solution follows (shown in order of decreasing rate or ease of dissolution).

$\operatorname{Iron}^{52}$ :

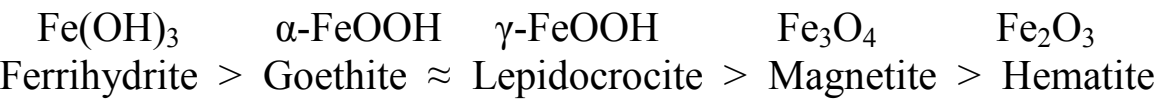

Aluminum $^{53}$ :

$$
\underset{\text { Gibbsite }}{\mathrm{Al}(\mathrm{OH})_{3}} \approx \text { Bayerite }>\text { Boehmite } \approx \text { Diaspore }>\text { Corundum (Alumina) }
$$

Manganese $e^{54}$ :

$$
\begin{aligned}
& \begin{array}{llllll}
\mathrm{Mn}(\mathrm{OH})_{2} & \gamma-\mathrm{MnOOH} & \mathrm{MnO} & \mathrm{Mn}_{2} \mathrm{O}_{3} & \mathrm{MnO}_{2} & \mathrm{Mn}_{3} \mathrm{O}_{4}
\end{array} \\
& \text { Pyrochroite }>\text { Manganite }>\text { Manganosite }>\text { Bixbyite }>\text { Pyrolusite }>\text { Hausmannite }
\end{aligned}
$$

A general rule for dissolution is that the farther an oxide is from a hydrated form (with hydroxide), the longer it takes for it to dissolve. For example $\mathrm{Mn}_{3} \mathrm{O}_{4}$ converts to $\mathrm{MnOOH}$ in nitric acid before it is dissolved. The extra step decreases the dissolution kinetics. A clearer example of the reaction order of iron oxide compounds in shown in Figure 12. Inspection of Figure 12 reveals that goethite dissolves faster than hematite. 




Figure 12 The Dissolution of Iron Oxide Compounds in 6 M HCl

(From Cornell, R. M., Posner A. M. and Quirk, J. P., “Kinetics and Mechanism of the acid dissolution of Goethite," J. Inorg. Nucl. Chem. 38, (1976), pp 563-567)

A literature review extracted the measured dissolution rates of each oxide compound for different cleaning agents. Table 21 provides a summary of the dissolution rates including the literature references. The effect of different acidic cleaning agents on the dissolution of ferrihydrite and goethite is shown in Figure 13. Ferrihydrite can be expected to dissolve more readily than Goethite. The experimental results are consistent with this expectation.



Figure 13 The Effect of the Complexing, Reducing and Acidic Agents on the Dissolution of Ferrihydrite and Goethite

Note: The concentration of each of the chemicals given in the abscissa equals $0.1 \mathrm{M}$.

(From G. J. Houben, “Iron Oxide Incrustations in Wells. Part 2: Chemical Dissolution and Modeling, ” Applied Geochemistry, 18 (2003), pp 941-954) 
Table 21 The Dissolution Rate of Common Sludge Compounds in Cleaning Solutions

\begin{tabular}{|c|c|c|c|c|c|c|}
\hline Species & $\begin{array}{c}\text { Dissolution Rate } \\
(\mathrm{mg} / \mathrm{h})\end{array}$ & Solid/Solution Ratio & $\begin{array}{c}\text { Surface Area } \\
\left(\mathrm{m}^{2} / \mathrm{g}\right)\end{array}$ & \% Dissolved & $\begin{array}{c}\text { Temp } \\
\left({ }^{\circ} \mathrm{C}\right)\end{array}$ & Solution \\
\hline Goethite & $0.05 \%$ per minute & $0.045 \mathrm{~g} / 0.5 \mathrm{~L}$ & 93 & $\begin{array}{l}23 \% \text { in } 425 \\
\min \end{array}$ & 25 & 0.1M Ascorbic acid \\
\hline Goethite & Not measured & $0.045 \mathrm{~g} / 0.5 \mathrm{~L}$ & 93 & $\begin{array}{l}20 \% \text { in } 425 \\
\min \end{array}$ & 25 & $0.1 \mathrm{M}$ Citric acid \\
\hline Goethite & $\begin{array}{l}0.006 \% \text { per } \\
\text { minute }\end{array}$ & $0.045 \mathrm{~g} / 0.5 \mathrm{~L}$ & 93 & $\begin{array}{c}3 \% \text { in } 425 \\
\text { min }\end{array}$ & 25 & $0.1 \mathrm{M}$ Citric acid \\
\hline Goethite & $\begin{array}{l}0.0251 \% \text { per } \\
\text { minute }\end{array}$ & $0.045 \mathrm{~g} / 0.5 \mathrm{~L}$ & 93 & $\begin{array}{l}10 \% \text { in } 425 \\
\min \end{array}$ & 25 & 0.1 M Malonic acid \\
\hline Goethite & $\begin{array}{l}0.026 \% \text { per } \\
\text { minute }\end{array}$ & $0.045 \mathrm{~g} / 0.5 \mathrm{~L}$ & 93 & $\begin{array}{l}10 \% \text { in } 400 \\
\min \end{array}$ & 25 & $0.1 \mathrm{~N} \mathrm{H}_{2} \mathrm{SO}_{4}$ \\
\hline Goethite & $\begin{array}{l}0.0248 \% \text { per } \\
\text { minute }\end{array}$ & $0.045 \mathrm{~g} / 0.5 \mathrm{~L}$ & 93 & $\begin{array}{l}10 \% \text { in } 425 \\
\min \end{array}$ & 25 & $0.1 \mathrm{M} \mathrm{HCl}$ \\
\hline Goethite & $0.61 \%$ per minute & $0.045 \mathrm{~g} / 0.5 \mathrm{~L}$ & 93 & $\begin{array}{c}100 \% \text { in } 75 \\
\min \end{array}$ & 25 & $0.1 \mathrm{M}$ Oxalic acid ${ }^{52}$ \\
\hline Goethite & $15 \%$ per minute & $0.045 \mathrm{~g} / 0.5 \mathrm{~L}$ & 93 & $\begin{array}{c}100 \% \text { in } 70 \\
\text { min }\end{array}$ & 25 & $0.1 \mathrm{M} \mathrm{NaS}_{2} \mathrm{O}_{4}$ \\
\hline Lepidocrite & $\begin{array}{l}4.5 \% \text { dissolved } \\
\text { per minute }\end{array}$ & $0.045 \mathrm{~g} / 0.5 \mathrm{~L}$ & 80 & $\begin{array}{l}100 \% \text { in } 170 \\
\min \end{array}$ & 25 & $0.1 \mathrm{M} \mathrm{NaS}_{2} \mathrm{O}_{4}$ \\
\hline \multicolumn{7}{|l|}{ Magnetite } \\
\hline Hematite & $10^{-11} \mathrm{~mol} / \mathrm{m}^{2} \mathrm{sec}$ & $0.75 \mathrm{~g} / 100 \mathrm{~mL}$ & & & & $\begin{array}{l}\mathrm{HNO}_{3} \\
\mathrm{pH}=1\end{array}$ \\
\hline Hematite & $\begin{array}{c}100 \% / 50 \mathrm{~h} \\
100 \% / 120 \mathrm{~h} \\
60 \% / 100 \mathrm{~h} \\
30 \% / 150 \mathrm{~h} \\
\end{array}$ & $0.00022 \mathrm{~g} / \mathrm{mL}$ & Not measured & & $\begin{array}{l}80 \\
70 \\
60 \\
50 \\
\end{array}$ & Oxalic acid \\
\hline Ferrihydrite & Not measured & $0.0535 \mathrm{~g} / 0.5 \mathrm{~L}$ & 309 & $\begin{array}{c}24 \% \text { in } 425 \\
\text { min }\end{array}$ & 25 & $0.1 \mathrm{M} \mathrm{NaOH}^{52}$ \\
\hline Ferrihydrite & $\begin{array}{l}1500 / 12 \text { or } 1.56 \\
\text { E- } 6 \mathrm{~mol} / \mathrm{day}^{*} \mathrm{~m}^{2}\end{array}$ & $1.5 \mathrm{~g} / 1 \mathrm{~L}$ & 195 & & 25 & $\mathrm{HNO}_{3} \mathrm{pH}=1^{52}$ \\
\hline Ferrihydrite & $\begin{array}{c}0.0315 \% \\
\text { dissolved per } \\
\text { minute }\end{array}$ & $0.0535 \mathrm{~g} / 0.5 \mathrm{~L}$ & 309 & $\begin{array}{c}13 \% \text { in } 425 \\
\min \end{array}$ & 25 & $0.1 \mathrm{M}$ Citric $\operatorname{acid}^{52}$ \\
\hline Ferrihydrite & $\begin{array}{c}0.1037 \% \\
\text { dissolved per } \\
\text { minute }\end{array}$ & $0.0535 \mathrm{~g} / 0.5 \mathrm{~L}$ & 309 & $\begin{array}{c}47 \% \text { in } 450 \\
\min \end{array}$ & 25 & $0.1 \mathrm{M} \mathrm{HCl}^{52}$ \\
\hline Ferrihydrite & $\begin{array}{c}0.5363 \% \\
\text { dissolved per } \\
\text { minute }\end{array}$ & $0.0535 \mathrm{~g} / 0.5 \mathrm{~L}$ & 309 & $\begin{array}{l}100 \% \text { in } 200 \\
\min \end{array}$ & 25 & $0.1 \mathrm{~N} \mathrm{H}_{2} \mathrm{SO}_{4}^{52}$ \\
\hline Ferrihydrite & $\begin{array}{l}0.08 \% \text { dissolved } \\
\text { per minute }\end{array}$ & $0.0535 \mathrm{~g} / 0.5 \mathrm{~L}$ & 309 & $\begin{array}{c}17 \% \text { in } 425 \\
\min \end{array}$ & 25 & $0.1 \mathrm{M}$ Sulfamic $\mathrm{acid}^{52}$ \\
\hline Ferrihydrite & $\begin{array}{l}0.25 \% \text { dissolved } \\
\text { per minute }\end{array}$ & $0.0535 \mathrm{~g} / 0.5 \mathrm{~L}$ & 309 & $\begin{array}{c}100 \% \text { in } 400 \\
\min \end{array}$ & 25 & $0.1 \mathrm{M}$ Malonic acid ${ }^{52}$ \\
\hline Ferrihydrite & $15 \%$ per minute & $0.0535 \mathrm{~g} / 0.5 \mathrm{~L}$ & 309 & $\begin{array}{c}100 \% \text { in } 70 \\
\min \end{array}$ & 25 & $0.1 \mathrm{M} \mathrm{NaS}_{2} \mathrm{O}_{4}$ \\
\hline Ferrihydrite & $\begin{array}{l}5.7 \% \text { dissolved } \\
\text { per minute }\end{array}$ & $0.0535 \mathrm{~g} / 0.5 \mathrm{~L}$ & 309 & $\begin{array}{l}100 \% \text { in } 40 \\
\min \end{array}$ & 25 & $0.1 \mathrm{M} \mathrm{Oxalic}^{52}$ \\
\hline Boehmite & $\begin{array}{l}0.045 \% \text { dissolved } \\
\text { per minute }\end{array}$ & $\begin{array}{c}8 \text { mols }[\mathrm{OH}] / 1 \mathrm{~mol} \\
\text { of } \mathrm{Al}\end{array}$ & Not measured & $\begin{array}{l}93 \% \text { in } 100 \\
\text { hours }\end{array}$ & 85 & $8 \mathrm{M} \mathrm{NaOH}^{53}$ \\
\hline Gibbsite & $\begin{array}{l}0.55 \% \text { dissolved } \\
\text { per minute }\end{array}$ & $\begin{array}{c}4 \text { mols }[\mathrm{OH}] / 1 \mathrm{~mol} \\
\text { of } \mathrm{Al}\end{array}$ & Not measured & $\begin{array}{c}100 \% \text { in } 16 \\
\text { hours }\end{array}$ & 65 & $5 \mathrm{M} \mathrm{NaOH}^{53}$ \\
\hline Alumina & $10^{-13} \mathrm{~mol} / \mathrm{m}^{2} \mathrm{sec}$ & $1.87 \mathrm{~g} / 75 \mathrm{~mL}$ & & & 25 & $\begin{array}{l}\mathrm{HNO}_{3} \\
\mathrm{pH}=1\end{array}$ \\
\hline $\mathrm{MnOOH}$ & $\begin{array}{c}2 \times 10^{-8} \\
\mathrm{~mol} / \mathrm{g}^{*} \mathrm{sec}\end{array}$ & & & & 25 & $\begin{array}{c}\mathrm{pH}=6 \\
\text { NaOxalate }^{55}\end{array}$ \\
\hline $\mathrm{MnOOH}$ & $\begin{array}{c}2 \times 10^{-6} \\
\mathrm{~mol} / \mathrm{g}^{*} \mathrm{sec}\end{array}$ & $\begin{array}{l}0.1 \mathrm{~g} / \mathrm{L} \text { in } \\
1.5 \mathrm{~L}\end{array}$ & Not measured & $95 \%$ in $10 \mathrm{hrs}$ & 25 & $\begin{array}{c}\mathrm{pH}=7.2 \\
\text { EDTA } \\
(50 \mathrm{mM})^{56}\end{array}$ \\
\hline $\mathrm{MnOOH}$ & $\begin{array}{c}2 \times 10^{-7} \\
\mathrm{~mol} / \mathrm{g}^{*} \mathrm{sec}\end{array}$ & $\begin{array}{l}0.1 \mathrm{~g} / \mathrm{L} \text { in } \\
1.5 \mathrm{~L}\end{array}$ & Not measured & $\begin{array}{c}66 \% \text { in } 110 \\
\text { hrs }\end{array}$ & 25 & $\begin{array}{c}\mathrm{pH}=8 \\
\text { Citrate } \\
(50 \mathrm{mM})^{56}\end{array}$ \\
\hline
\end{tabular}

Table 21 The Dissolution Rate of Common Sludge Compounds in Cleaning Solutions 
WSRC-TR-2003-00401

(continued)

\begin{tabular}{|c|c|c|c|c|c|c|}
\hline $\mathrm{MnOOH}$ & $\begin{array}{c}8 \times 10^{-8} \\
\mathrm{~mol} / \mathrm{g}^{*} \mathrm{sec}\end{array}$ & $\begin{array}{l}0.22 \mathrm{~g} / \mathrm{L} \text { in } \\
1.5 \mathrm{~L}\end{array}$ & Not measured & $\begin{array}{c}100 \% \text { in } 1 \\
\text { day }\end{array}$ & 25 & $\begin{array}{c}\text { PyroPhosphate } \\
\mathrm{P}_{2} \mathrm{O}_{7}^{4-}(50 \mathrm{mM}) \\
\mathrm{pH}=8^{56}\end{array}$ \\
\hline $\mathrm{MnO}$ & $\begin{array}{c}<4 \times 10^{-3} \\
\mathrm{~L} / \mathrm{mol}^{*} \mathrm{sec}\end{array}$ & $\begin{array}{c}3.54 \times 10^{-5} \mathrm{~mol} / \mathrm{L} \text { in } \\
1.77 \times 10^{-5} \mathrm{M} \\
\text { Reductant }\end{array}$ & Not Measured & Not reported & 25 & Oxalate $^{57}$ \\
\hline $\mathrm{MnO}$ & $20 \mathrm{~L} / \mathrm{mol}^{*} \mathrm{sec}$ & $\begin{array}{c}3.54 \times 10^{-5} \mathrm{~mol} / \mathrm{L} \text { in } \\
1.77 \times 10^{-5} \mathrm{M} \\
\text { Reductant }\end{array}$ & Not Measured & Not reported & 25 & Ascorbate $^{57}$ \\
\hline $\mathrm{Mn}_{3} \mathrm{O}_{4}$ & & $\begin{array}{c}3.54 \times 10^{-5} \mathrm{~mol} / \mathrm{L} \text { in } \\
1.77 \times 10^{-5} \mathrm{M} \\
\text { Reductant }\end{array}$ & & & & \\
\hline $\mathrm{Mn}_{3} \mathrm{O}_{4}$ & $\begin{array}{l}5 \% \text { dissolved per } \\
\text { minute }\end{array}$ & $0.340 \mathrm{~g} \mathrm{He} 200 \mathrm{~mL}$ & Not measured & $\begin{array}{c}100 \% \text { in } 50 \\
\text { hrs }\end{array}$ & 80 & $\begin{array}{c}\text { Citric:EDTA:Gallic acid } \\
11: 44: 4 \mathrm{mM}^{58}\end{array}$ \\
\hline \multicolumn{7}{|l|}{$\mathrm{Mn}_{2} \mathrm{O}_{3}$} \\
\hline $\begin{array}{c}\text { Crancrinite and } \\
\text { sodalite }\end{array}$ & $\begin{array}{c}6 \times 10^{-5} \\
\mathrm{~mol} / \mathrm{L} * \mathrm{hrs}\end{array}$ & Not mentioned & Not measured & $\begin{array}{c}2 \% \text { dissolved } \\
\text { in } 5 \mathrm{hrs} \\
\end{array}$ & 90 & Distilled water ${ }^{59}$ \\
\hline $\begin{array}{l}\text { Crancrinite and } \\
\text { sodalite }\end{array}$ & $\begin{array}{l}3.5 \times 10^{-4} \\
\mathrm{~mol} / \mathrm{L} * \mathrm{hrs}\end{array}$ & $0.33 \mathrm{~g}$ in $50 \mathrm{~mL}$ & Not measured & $\begin{array}{c}100 \% \\
\text { dissolved in } 5 \\
\text { hrs }\end{array}$ & 90 & $\begin{array}{l}\text { Oxalic acid (strength not } \\
\text { mentioned) }\end{array}$ \\
\hline $\begin{array}{l}\text { Crancrinite and } \\
\text { sodalite }\end{array}$ & $\begin{array}{c}2 \times 10^{-3} \\
\mathrm{~mol} / \mathrm{L} * \mathrm{hrs}\end{array}$ & $0.33 \mathrm{~g}$ in $50 \mathrm{~mL}$ & Not measured & $\begin{array}{c}100 \% \\
\text { dissolved in } 3 \\
\text { hrs } \\
\end{array}$ & 90 & 1.5 M Nitric ${ }^{60}$ Acid \\
\hline $\mathrm{Na}_{2} \mathrm{U}_{2} \mathrm{O}_{7}$ & $\begin{array}{l}0.59 \% \text { dissolved } \\
\text { per min }\end{array}$ & $\begin{array}{c}\mathrm{U} \text { in } 0.33 \mathrm{~g} \text { of NAS } \\
\text { in } 50 \mathrm{~mL}\end{array}$ & Not Measured & $\begin{array}{c}100 \% \\
\text { dissolved in } \\
3.5 \mathrm{hrs} \\
\end{array}$ & 25 & 1.5 M Nitric acid ${ }^{60}$ \\
\hline $\mathrm{Na}_{2} \mathrm{U}_{2} \mathrm{O}_{7}$ & Not measured & $\begin{array}{c}20 \mathrm{~g} \text { of soil in } 200 \\
\mathrm{~mL}\end{array}$ & Not Measured & $\begin{array}{c}70 \% \\
\text { dissolved in } \\
23 \mathrm{hrs} \\
\end{array}$ & 22 & 0.5 M Citric acid ${ }^{61}$ \\
\hline $\mathrm{Na}_{2} \mathrm{U}_{2} \mathrm{O}_{7}$ & Not measured & $\begin{array}{c}33 \mathrm{wt} \% \text { solids in } \\
25 \mathrm{~g} \text { of } \mathrm{NaHCO}_{3}+25 \\
\mathrm{~g} \text { of } \mathrm{NaCO}_{3} \text { in water } \\
\text { at } \mathrm{pH}=9\end{array}$ & Not Measured & $\begin{array}{c}75-80 \% \text { in } \\
23 \mathrm{hrs}\end{array}$ & 22 & $\begin{array}{l}25 \mathrm{~g} \text { of } \mathrm{NaHCO}_{3}+25 \mathrm{~g} \text { of } \\
\mathrm{NaCO}_{3} \text { in water at } \mathrm{pH}=9^{61}\end{array}$ \\
\hline
\end{tabular}

\subsection{SOLUBILITY OF SLUDGE COMPONENTS IN OXALIC ACID}

Minimal data exist that identify the solubility of specific sludge components in oxalic acid. These have been summarized in Table 22. Note that in many instances less than or greater than values are reported since only spot tests were conducted.

Table 22 Solubility of Various Sludge Components in Oxalic Acid 
WSRC-TR-2003-00401

\begin{tabular}{|c|c|c|c|c|}
\hline Substance & $\begin{array}{c}\text { Molecular } \\
\text { Weight(g/g-mole) }\end{array}$ & Density $\left(\mathrm{g} / \mathrm{cm}^{\mathbf{3}}\right)$ & $\begin{array}{l}\text { Solubility in } 0.1 \\
\text { M Oxalic Acid }\end{array}$ & Reference \\
\hline $\begin{array}{l}\mathrm{Al}(\mathrm{OH})_{3} \\
\text { Gibbsite }\end{array}$ & 78 & 2.44 & $10^{-3} \mathrm{M}$ & 45 \\
\hline $\begin{array}{c}\text { AlOOH } \\
\text { Boehmite }\end{array}$ & 60 & 3.62 & $<10^{-3} \mathrm{M}$ & 45 \\
\hline $\begin{array}{l}\text { AlOOH } \\
\text { Diaspore }\end{array}$ & 60 & 3.38 & $<10^{-3} \mathrm{M}$ & 45 \\
\hline $\begin{array}{c}\mathrm{Al}_{2} \mathrm{O}_{3} \\
\text { Corundum }\end{array}$ & 102 & 4 & Undetectable & 45 \\
\hline $\mathrm{NaAlO}_{2}$ (beta) & 82 & 2.7 & $10^{-4} \mathrm{M}$ & 45 \\
\hline $\begin{array}{c}\mathrm{Fe}_{3} \mathrm{O}_{4} \\
\text { Magnetite }\end{array}$ & 232 & 5.2 & $>0.001 \mathrm{M}$ & 62 \\
\hline $\begin{array}{c}\mathrm{Fe}_{2} \mathrm{O}_{3} \\
\text { Hematite }\end{array}$ & 160 & 5.25 & $>0.002 \mathrm{M}$ & 62 \\
\hline $\begin{array}{l}\mathrm{FeO}(\mathrm{OH}) \\
\text { Goethite }\end{array}$ & 90 & 3.4 & $>0.002 \mathrm{M}$ & 62 \\
\hline $\begin{array}{c}\mathrm{FeO} \\
\text { Iron Oxide }\end{array}$ & 72 & 6 & $>0.002 \mathrm{M}$ & 62 \\
\hline $\begin{array}{c}\mathrm{Fe}(\mathrm{OH})_{3} \\
\text { Ferrihydrite }\end{array}$ & 107 & 3.12 & $>0.002 \mathrm{M}$ & 62 \\
\hline $\begin{array}{c}\text { MnO } \\
\text { Manganosite }\end{array}$ & 71 & 5.37 & $>0.014 \mathrm{M}$ & 63 \\
\hline $\begin{array}{c}\mathrm{Mn}_{2} \mathrm{O}_{3} \\
\text { Bixbyite }\end{array}$ & 158 & 5 & $>0.014 \mathrm{M}$ & 63 \\
\hline $\begin{array}{c}\mathrm{MnO}_{2} \\
\text { Pyrolusite }\end{array}$ & 87 & 5 & $>0.014 \mathrm{M}$ & 63 \\
\hline $\begin{array}{l}\mathrm{MnO}(\mathrm{OH}) \\
\text { Manganite }\end{array}$ & 88 & 4.3 & $>0.014 \mathrm{M}$ & 63 \\
\hline
\end{tabular}


WSRC-TR-2003-00401

\subsection{ISSUES}

\subsection{CORROSION OF CARBON STEEL IN CHEMICAL CLEANING SOLUTIONS}

\subsubsection{Corrosion Mechanisms During Chemical Cleaning}

\subsubsection{Oxalic Acid}

Oxalic acid solutions have been frequently utilized to decontaminate steel components at nuclear facilities. The Savannah River Site has utilized oxalic acid to perform sludge heel removal in two waste tanks ${ }^{33,64}$ and also to clean out a reactor heat exchanger system. ${ }^{65}$ Oxalic acid is successful in these types of processes because it is a sufficiently strong and oxidizing acid that is able to dissolve iron oxides and corrode steel. These reactions tend to dislodge scale that might adhere to the surface and thus successfully decontaminate the surface.

The corrosion of iron in oxalic acid has also been investigated for many years. ${ }^{66}$ The anodic reactions are reported to be:

$\mathrm{Fe}=\mathrm{Fe}^{2+}+2 \mathrm{e}^{-}$

Equation 44

$\mathrm{Fe}=\mathrm{Fe}^{3+}+3 \mathrm{e}^{-}$

Equation 45

The cathodic reaction is the reduction of hydrogen ion to hydrogen gas. Two other reactions occur that impact the corrosion rate.

$\mathrm{Fe}^{3+}+3 \mathrm{C}_{2} \mathrm{O}_{4}{ }^{2-}=\mathrm{Fe}\left(\mathrm{C}_{2} \mathrm{O}_{4}\right)_{3}{ }^{3-}$

Equation 46

$2 \mathrm{Fe}\left(\mathrm{C}_{2} \mathrm{O}_{4}\right)_{3}{ }^{3-}=2 \mathrm{FeC}_{2} \mathrm{O}_{4}+3 \mathrm{C}_{2} \mathrm{O}_{4}{ }^{2-}+2 \mathrm{CO}_{2}$

Equation 47

The ferric oxalate anion $\left(\mathrm{Fe}\left(\mathrm{C}_{2} \mathrm{O}_{4}\right)_{3}{ }^{3-}\right)$ from Equation 46 is soluble and is recognizable by its lime green color in solution. This anion decomposes photocatalytically over a period of days per Equation 47, depending on the radiation intensity in the visible range. Consequently, a ferrous oxalate complex precipitates on the surface of the steel and markedly depresses the iron corrosion rate and passivates the steel. Thus, if ferric oxalate is not present near the surface, or there is not enough light, the process of passivation will be hindered. The corrosion is typically uniform (i.e., no pitting) due to this film. Therefore, if contact time between the acid and the steel is not excessively prolonged, corrosion will not be significant.

On the other hand, the precipitation of these salts reduces the effective cleaning power of the oxalic acid. ${ }^{67}$ In order to maintain the cleaning power, the acid could be refreshed and consequently the corrosion process would also be renewed. Tests have shown that if the acid is refreshed daily, less of the film forms and the corrosion rate approximately doubles. ${ }^{64}$ Thus 
when utilizing oxalic in chemical cleaning operations a balance between effective cleaning and minimizing corrosion must be achieved.

\subsubsection{Citric Acid}

Citric acid is not typically utilized by itself in chemical cleaning operations primarily because it does not effectively dissolve metal oxides. ${ }^{68}$ However, because the citric acid is able to complex with metal cations to form chelates, it has been utilized in combination with other acids. When a metal ion is chelated by citric acid, it remains in solution and is unable to react further. Thus, as $\mathrm{Fe}^{2+}$ and $\mathrm{Fe}^{3+}$ cations are produced by the corrosion reaction in the acidic solution, they are captured by the citric acid ligand and prevented from forming oxides or other insoluble complexes on the surface of the metal. These insoluble complexes typically inhibit corrosion and therefore corrosion rates in citric acid alone would likely be greater than that for an acid that formed an oxide.

\subsubsection{Oxalic Acid and Citric Acid}

A combination of organic acids is frequently utilized in a chemical cleaning process. ${ }^{69}$ One such combination is oxalic and citric acid. The oxalic acid is effective for dissolution of the metal oxides, while the citric acid reduces the amount of ferrous oxalate precipitates that form on the surface of the metal. This competition for the metal cations therefore maintains the effective cleaning power of the oxalic acid. However, because fewer of the metal ions are available to form the protective film, the metal will corrode at a faster rate. Thus optimizing the concentrations of the acids and the temperature of the cleaning process such that the cleaning power is maximized, while the corrosion rate is minimized, has been the goal of much of the research.

\subsubsection{Oxalic Acid and Hydrogen Peroxide}

The presence of hydrogen peroxide $\left(\mathrm{H}_{2} \mathrm{O}_{2}\right)$ to oxalic acid has a deleterious effect on the corrosion rate of carbon steel. ${ }^{64}$ The peroxide appears to breakdown the protective ferrous oxalate layer by the following reaction:

$2 \mathrm{FeC}_{2} \mathrm{O}_{4}+4 \mathrm{H}_{2} \mathrm{C}_{2} \mathrm{O}_{4}+\mathrm{H}_{2} \mathrm{O}_{2} \rightarrow 2 \mathrm{Fe}\left(\mathrm{C}_{2} \mathrm{O}_{4}\right)_{3}{ }^{3-}+2 \mathrm{H}_{2} \mathrm{O}+6 \mathrm{H}^{+}$

Equation 48

The result is that the ferric oxalate species remains in solution.

\subsubsection{Nitric Acid Corrosion Mechanism}

The nitric acid corrosion mechanism has been studied for many years. Although the anodic reaction is fairly simple, iron being oxidized to ferrous cation $\left(\mathrm{Fe}^{2+}\right)$, there are a number of cathodic reactions that occur in this process. ${ }^{64}$ The cathodic reduction of nitric acid likely proceeds in five steps.

Step 1: $\quad \mathrm{H}^{+}+\mathrm{e}^{-}=\mathrm{H}$ 
WSRC-TR-2003-00401

Step 2: $\quad \mathrm{HNO}_{3}+\mathrm{H}^{+}+\mathrm{e}^{-}=\mathrm{NO}_{2}+\mathrm{H}_{2} \mathrm{O}$

Equation 50

Step 3: $\quad \mathrm{NO}_{2}+\mathrm{e}^{-}=\mathrm{NO}_{2}{ }^{-}$

Equation 51

Step 4: $\quad \mathrm{H}^{+}+\mathrm{NO}_{2}^{-}=\mathrm{HNO}_{2}$

Equation 52

Step 5: $\quad \mathrm{HNO}_{2}+\mathrm{H}=\mathrm{NO}+\mathrm{H}_{2} \mathrm{O}$

Equation 53

The nitrous acid $\left(\mathrm{HNO}_{2}\right)$ that was formed in step 4 regenerates $\mathrm{NO}_{2}$ by an interaction with the nitric acid

$\mathrm{HNO}_{2}+\mathrm{HNO}_{3}=2 \mathrm{NO}_{2}+\mathrm{H}_{2} \mathrm{O}$

Equation 54

Thus the reaction becomes autocatalytic. Ammonia salts are also formed during the cathodic reaction. The ammonia salts decompose to form $\mathrm{N}_{2}$ and $\mathrm{NOx}$ compounds by the following reactions.

$\mathrm{NH}_{4} \mathrm{NO}_{2}=\mathrm{N}_{2}+2 \mathrm{H}_{2} \mathrm{O}$

Equation 55

$\mathrm{NH}_{4} \mathrm{NO} 3=\mathrm{N}_{2} \mathrm{O}+2 \mathrm{H}_{2} \mathrm{O}$

Equation 56

Thus formation of $\mathrm{NO}_{2}, \mathrm{NO}, \mathrm{N}_{2} \mathrm{O}$ and $\mathrm{N}_{2}$ (i.e., a brown gas should be emitted) due to the cathodic reaction is expected.

\subsubsection{Formic Acid Corrosion Mechanism}

Formic acid is a strong reducing acid, approaching the dilute mineral acids in its activity (i.e., its tendency to release hydrogen ions). ${ }^{70}$ The anodic reaction involves iron dissolution, while the cathodic reaction results in hydrogen generation. Corrosion of iron and carbon steel can be particularly aggressive at high temperatures and under anaerobic conditions. The acid has a tendency to decompose, liberating carbon monoxide and water.

\subsubsection{Review of Experimentally Determined Corrosion Rates}

A review was performed of the experimentally determined corrosion rates for oxalic acid, citric acid, and a combination of oxalic and citric acids. The important variables impacting the corrosion rate were acid concentration, carbon content of the metal, temperature and length of exposure. Each of these variables is discussed below. 


\subsubsection{Oxalic Acid}

Table 23 shows corrosion rate data for carbon steel in oxalic acid under various environmental conditions. Data reported by Ondrejcin ${ }^{64}$ was collected from coupon tests that were performed at SRS to provide the technical basis for chemical cleaning of Tank $16 \mathrm{H}$. Data reported by Wilde ${ }^{65}$

Table 23 Oxalic Acid Corrosion Rate Data

\begin{tabular}{|c|c|c|c|c|c|}
\hline $\begin{array}{c}\text { Type of Test } 7 \\
\text { \& Reference }\end{array}$ & $\begin{array}{l}\text { Steel (wt \% } \\
\text { carbon) }\end{array}$ & $\begin{array}{c}\text { Solution } \\
\text { Concentration } \\
\text { (M) }\end{array}$ & $\begin{array}{c}\text { Temperature } \\
\left({ }^{\circ} \mathrm{C}\right)\end{array}$ & $\begin{array}{c}\text { Test } \\
\text { Duration } \\
\text { (h) }\end{array}$ & $\begin{array}{c}\text { Corrosion } \\
\text { Rate } \times 10^{-5} \\
\text { (inches/h) }\end{array}$ \\
\hline \multirow{9}{*}{ Coupon $^{64}$} & \multirow{9}{*}{ Max. 0.3} & \multirow{3}{*}{0.45} & 75 & 336 & 0.23 \\
\hline & & & 85 & 168 & 0.30 \\
\hline & & & 95 & 168 & 0.25 \\
\hline & & \multirow{3}{*}{0.91} & 75 & 336 & 0.23 \\
\hline & & & 85 & 168 & 0.30 \\
\hline & & & 95 & 168 & 0.25 \\
\hline & & \multirow{3}{*}{1.39} & 75 & 336 & 0.23 \\
\hline & & & 85 & 168 & 0.30 \\
\hline & & & 95 & 168 & 0.33 \\
\hline \multirow{3}{*}{ Coupon $^{71}$} & \multirow{3}{*}{0.06} & \multirow{3}{*}{0.19} & 20 & 46 & 0.18 \\
\hline & & & 80 & 46 & 0.39 \\
\hline & & & Boiling point & 6 & 1.83 \\
\hline $\begin{array}{l}\text { Coupon during } \\
\text { bench scale } \\
\text { dissolution } \\
\text { (stirring) }^{71}\end{array}$ & 0.06 & 0.89 & 20 & 24 & 0.63 \\
\hline \multirow{6}{*}{ Coupon $^{72}$} & \multirow{6}{*}{ Max. 0.18} & \multirow{3}{*}{0.45} & 50 & 168 & 0.42 to 1.35 \\
\hline & & & 50 & 336 & 0.86 to 1.26 \\
\hline & & & 50 & 504 & 1.44 to 1.88 \\
\hline & & \multirow{3}{*}{0.91} & 50 & 168 & 0.34 to 0.53 \\
\hline & & & 50 & 336 & 0.18 to 0.23 \\
\hline & & & 50 & 504 & 0.18 to 0.23 \\
\hline \multirow{12}{*}{ Coupon $^{73}$} & \multirow{12}{*}{ Max. 0.18} & \multirow{6}{*}{0.45} & 27 & 48 & 0.22 \\
\hline & & & 27 & 96 & 0.30 \\
\hline & & & 27 & 144 & 0.45 \\
\hline & & & 50 & 48 & 0.99 \\
\hline & & & 50 & 96 & 1.72 \\
\hline & & & 50 & 144 & 1.82 \\
\hline & & \multirow{6}{*}{0.91} & 27 & 48 & 0.22 \\
\hline & & & 27 & 96 & 0.29 \\
\hline & & & 27 & 144 & 0.45 \\
\hline & & & 50 & 48 & 1.1 \\
\hline & & & 50 & 96 & 1.59 \\
\hline & & & 50 & 144 & 1.6 \\
\hline \multirow{3}{*}{$\begin{array}{c}\text { Coupon } \\
\text { (Stirring) })^{73}\end{array}$} & \multirow[t]{3}{*}{ Max. 0.18} & \multirow{3}{*}{0.91} & 50 & 48 & 0.44 \\
\hline & & & 50 & 96 & 0.63 \\
\hline & & & 50 & 144 & 0.48 \\
\hline \multirow{4}{*}{ Electrochemical $^{74}$} & 0.1 & \multirow{4}{*}{$0.05(\mathrm{pH} 2.8)$} & \multirow{4}{*}{30} & \multirow{4}{*}{ NA } & 0.6 \\
\hline & 0.25 & & & & 0.9 \\
\hline & 0.5 & & & & 2.1 \\
\hline & 0.65 & & & & 0.9 \\
\hline
\end{tabular}


WSRC-TR-2003-00401

\begin{tabular}{|c|c|c|c|c|c|}
\hline & 0.75 & & & & 0.3 \\
\hline \multirow{3}{*}{ Coupon $^{75}$} & \multirow{3}{*}{ NA } & \multirow{3}{*}{0.001} & 20 & \multirow{3}{*}{24} & 1.25 \\
\hline & & & 38 & & 1.67 \\
\hline & & & 72 & & 2.5 \\
\hline
\end{tabular}

was collected from coupon tests that were performed at SRS in support of cleaning of the reactor heat exchangers. Data was collected from a recent Russian investigation on the effectiveness of oxalic acid cleaning of sludge. ${ }^{71}$ Data was also obtained from separate coupon studies performed at Pacific Northwest National Laboratory that were related to the clean-out of high level waste tanks at West Valley. ${ }^{72,73}$ Additional data was collected from a journal article written by a group from Egypt that performed electrochemical tests to determine among other things the influence of carbon content in the metal on the corrosion rate. ${ }^{74}$

Several observations can be made with regard to the corrosion rate data.

- The corrosion rate decreases as the concentration of oxalic acid increases. This observation is probably related to the limited amount of ferrous oxalate that forms and is available to adsorb to the metal surface at the lower acid concentrations.

- There appears to be a concentration of oxalic acid (between 0.2 to $0.45 \mathrm{M}$ ) at which further increase in the concentration does not retard the corrosion rate any further. This observation may be related to the possibility that the available cathodic sites to which the ferrous oxide may attach have become saturated.

- Temperature has a strong effect on the corrosion rate. The corrosion rate appears to be at a maximum at a temperature of $50{ }^{\circ} \mathrm{C}$.

- The corrosion rate in general increases due to agitation. The agitation is expected to increase the diffusion of reactants through the ferrous oxalate layer and hence increase the corrosion rate. However, data by Elmore ${ }^{73}$ suggests contrary behavior. The author was unable to explain this behavior.

- The corrosion rate is a maximum at a carbon concentration in the metal of approximately $0.5 \mathrm{wt} \%$. This correlates with a maximum in the area of the $\mathrm{Fe}_{3} \mathrm{C}$ phase (cathodic sites) at approximately $0.6 \mathrm{wt} \%$ carbon.

In the past, SRS has performed chemical cleaning of sludge with solutions that were less than 0.9 $\mathrm{M}(8 \mathrm{wt} \%)$ and at temperatures of approximately $85^{\circ} \mathrm{C}$. The contact times were limited to less than 2 weeks. Since the acid was refreshed and stirred during the operation, the corrosion rate would be expected to be approximately double the rate shown by Ondrejcin. ${ }^{64}$ The metal loss during this cleaning process was likely about 0.002 to 0.003 inches. Given that the steel at this location of the tank is on the order of 0.875 inches the metal loss would be acceptable.

\subsubsection{Citric Acid}

Table 24 shows corrosion rate data for carbon steel in citric acid under various environmental conditions. Data was collected from a journal article written by a group from Egypt that performed electrochemical tests that among other things compared the corrosion rates of iron in oxalic acid versus those in citric acid. ${ }^{74}$ Data was also collected from coupon tests that were examining the corrosiveness of mixtures of organic acids on carbon steel. ${ }^{67}$ Citric acid was 
utilized for the control experiment. Data was obtained from the literature and its application is unknown. ${ }^{75}$

Several observations can be made in regard to the corrosion rate data.

- The rate of corrosion is 2 to 3 times greater in citric acid than in oxalic acid. This increase was expected due to the lack of an oxide or oxalate on the metal surface.

- The effect of temperature on the corrosion rate appears to be greater for citric acid than for oxalic acid. An increase in temperature will significantly increase the corrosion rate.

- Flowing water provides a means by which the solution may be refreshed and agitated. The result is relatively high corrosion rates. The corrosion rates shown in Table 24 are equivalent to 3 to 4 inches per year. Or, if this process were allowed to occur for 2 weeks it is estimated that approximately 0.14 inches ( $16 \%$ of the wall thickness) of the metal could be lost.

Table 24 Citric Acid Corrosion Data

\begin{tabular}{|c|c|c|c|c|c|}
\hline Type of Test & $\begin{array}{c}\text { Steel (wt \% } \\
\text { carbon) }\end{array}$ & $\begin{array}{c}\text { Solution } \\
\text { Concentration } \\
(\mathrm{M}) \\
\end{array}$ & $\begin{array}{c}\text { Temperature } \\
\left({ }^{\circ} \mathrm{C}\right)\end{array}$ & $\begin{array}{c}\text { Test } \\
\text { Duration (h) }\end{array}$ & $\begin{array}{l}\text { Corrosion } \\
\text { Rate } x 1^{-5} \\
\text { (inches } / h \text { ) }\end{array}$ \\
\hline \multirow{5}{*}{$\begin{array}{l}\text { Electrochemical } \\
74\end{array}$} & 0.1 & \multirow{5}{*}{0.05 (pH 2.8) } & \multirow{5}{*}{30} & \multirow{5}{*}{ NA } & 1.30 \\
\hline & 0.25 & & & & 1.50 \\
\hline & 0.5 & & & & 3.12 \\
\hline & 0.65 & & & & 1.64 \\
\hline & 0.75 & & & & 1.47 \\
\hline \multirow{2}{*}{$\begin{array}{c}\text { Coupon in } \\
\text { flowing water - } \\
6 \mathrm{~mL} / \mathrm{s}^{67}\end{array}$} & \multirow[t]{2}{*}{ Max. 0.25} & \multirow[t]{2}{*}{0.004} & 90 & \multirow[t]{2}{*}{22} & $27.3 \pm 3.9$ \\
\hline & & & 117 & & $42.9 \pm 15.6$ \\
\hline \multirow[t]{2}{*}{$\mathrm{NA}^{75}$} & \multirow[t]{2}{*}{ NA } & \multirow[t]{2}{*}{3.24} & 25 & \multirow[t]{2}{*}{ NA } & 2.1 \\
\hline & & & 50 & & 14.7 \\
\hline
\end{tabular}

\subsubsection{Oxalic Acid and Citric Acid Mixtures}

Table 25 shows corrosion rate data for carbon steel in a combination of oxalic and citric acid under various environmental conditions. Data was collected from a recent Russian investigation on the effectiveness of oxalic and citric acid cleaning of sludge. ${ }^{71}$ Data was also collected from coupon tests that were examining the corrosiveness of mixtures of organic acids on carbon steel. ${ }^{67}$ Ondrejcin's data was collected from coupon tests performed at SRS that were examining the corrosiveness of a proprietary decontamination solution on carbon steel. ${ }^{64}$ The solution was a blend of oxalic, citric, and tartaric acids along with a corrosion inhibitor and surfactants.

Several observations can be made in regard to the corrosion rate data.

- The results of the tests performed in flowing water indicate that as the oxalic acid concentration is increased relative to the citric acid concentration, the corrosion rate decreased. The formation of the ferrous oxalate film is likely responsible for the inhibition at higher oxalic acid concentrations. 
- There is good agreement between the corrosion rate data reported in Reference 64 and Reference 71. Unfortunately a complete comparison cannot be made since the composition of the solution in Reference 64 is unknown and the solution also contains other constituents.

- The data in Reference 71 suggests that the corrosion rates for the oxalic/citric acid mixture are slightly less than those for oxalic acid. Therefore, the metal loss due to corrosion would be expected to be on the same order of magnitude as that for oxalic acid.

- At a constant concentration, the corrosion rate appears to increase with temperature and to be a relatively strong effect. This result is similar to that for the citric acid. The exception appears to be the flowing water tests where the scatter in the data does not allow for conclusions to be drawn.

- Given that the chemical cleaning process will involve some degree of agitation, it would be beneficial to be able to compare the corrosion results from bench scale sludge dissolution tests with the oxalic acid versus those with the oxalic/citric acid mixture. Although Reference 71 suggests that coupons were immersed during bench scale tests, metal loss from the coupon was not determined.

Table 25 Oxalic and Citric Acid Corrosion of Carbon Steel

\begin{tabular}{|c|c|c|c|c|c|}
\hline Type of Test & $\begin{array}{l}\text { Steel (wt \% } \\
\text { carbon) }\end{array}$ & $\begin{array}{c}\text { Solution } \\
\text { Concentration } \\
(\mathbf{M}) \\
\end{array}$ & $\begin{array}{c}\text { Temperature } \\
\left({ }^{\circ} \mathrm{C}\right)\end{array}$ & $\begin{array}{c}\text { Test } \\
\text { Duration } \\
\text { (hours) }\end{array}$ & $\begin{array}{c}\text { Corrosion } \\
\text { Rate } x \mathbf{1 0}^{-5} \\
\text { (inches/hour) } \\
\end{array}$ \\
\hline \multirow{3}{*}{ Coupon $^{71}$} & \multirow{3}{*}{0.06} & \multirow{3}{*}{$\begin{array}{l}\text { Oxalic: } 0.093 \\
\text { Citric: } 0.049\end{array}$} & 20 & \multirow[b]{2}{*}{46} & 0.14 \\
\hline & & & 80 & & 0.31 \\
\hline & & & Boiling Point & 6 & 1.21 \\
\hline \multirow{4}{*}{$\begin{array}{l}\text { Coupon in } \\
\text { flowing water - } \\
6 \mathrm{~mL} / \mathrm{s}^{67}\end{array}$} & \multirow{4}{*}{ Max. 0.25} & \multirow{2}{*}{$\begin{array}{l}\text { Oxalic: } 0.0022 \\
\text { Citric: } 0.0014\end{array}$} & 90 & \multirow{4}{*}{22} & NA \\
\hline & & & 117 & & $35.1 \pm 23.4$ \\
\hline & & \multirow{2}{*}{$\begin{array}{l}\text { Oxalic: } 0.0044 \\
\text { Citric: } 0.0014\end{array}$} & 90 & & $19.5 \pm 3.9$ \\
\hline & & & 117 & & $11.7 \pm 15.6$ \\
\hline \multirow{9}{*}{$\begin{array}{l}\text { Coupon tests in } \\
\text { Decon } 4518^{* 64}\end{array}$} & \multirow{9}{*}{ Max. 0.3} & \multirow{3}{*}{$4 \mathrm{wt} \%$} & 75 & 336 & 0.21 \\
\hline & & & 85 & 168 & 0.57 \\
\hline & & & 95 & 168 & 0.73 \\
\hline & & \multirow{3}{*}{$8 \mathrm{wt} \%$} & 75 & 336 & 0.31 \\
\hline & & & 85 & 168 & 0.57 \\
\hline & & & 95 & 168 & 0.80 \\
\hline & & \multirow{3}{*}{$12 \mathrm{wt} \%$} & 75 & 336 & 0.33 \\
\hline & & & 85 & 168 & 0.57 \\
\hline & & & 95 & 168 & 0.86 \\
\hline
\end{tabular}

* Decon 4518 a proprietary blend of oxalic, citric, and tartaric acids with a corrosion inhibitor and surfactants. The molar concentrations of each acid are unknown.

\subsubsection{Oxalic Acid and Hydrogen Peroxide}

Extremely high corrosion rates were observed in the small-scale laboratory tests with mixtures of oxalic acid and hydrogen peroxide. ${ }^{36}$ The actual rates may be slower. As dissolution proceeds the $\mathrm{pH}$ and the dissolved Fe concentrations increase. This increases the decomposition rate of hydrogen peroxide and thus lowers the corrosion rate. Table 25 provides corrosion rate data for 
carbon steel in contact with mixtures of oxalic acid and hydrogen peroxide as a function of temperature. The highest corrosion rate occurred at $80{ }^{\circ} \mathrm{C}$.

Table 26 Corrosion Rate of Carbon Steel in Oxalic Acid-Hydrogen Peroxide as a Function of Temperature

\begin{tabular}{|c|c|}
\hline Temperature $(\mathrm{C})$ & $\begin{array}{c}\text { Corrosion Rate } \\
\text { (inches/year) }\end{array}$ \\
\hline 18 & 6.13 \\
\hline 80 & 131 \\
\hline 100 & 105 \\
\hline
\end{tabular}

\subsubsection{Nitric Acid}

Iron differs from many metals in that the corrosion rate at room temperature increases with acid concentration, up to approximately $6 \mathrm{M}$, and then decreases dramatically. The decrease is attributed to the formation of a passive ferric oxide film on the surface. Unless the ferric oxide film is disturbed, (i.e., mechanically ruptured or reduced), the carbon steel surface will remain passivated. Above approximately $20 \mathrm{M}$ nitric acid the corrosion rate increases significantly once again.

Passivation of nitric acid is also temperature sensitive. Essentially no passivation at any concentration is observed at temperatures above $75{ }^{\circ} \mathrm{C} .{ }^{76}$ Experimental data for the corrosion of carbon steel in nitric acid at room temperature is shown in Table $27.77,78,79$

Table 27 Nitric Acid Corrosion of Carbon Steel at $25^{\circ} \mathrm{C}$

\begin{tabular}{|c|c|c|}
\hline $\begin{array}{c}\text { Concentration } \\
(\mathrm{M})\end{array}$ & $\begin{array}{c}\text { Corrosion } \\
\text { Rate (inches } \\
\text { per year) }\end{array}$ & Reference \\
\hline 0.3 & 0.4 & 66 \\
\hline 1.0 & 2.0 & 65 \\
\hline 1.7 & 1.75 & 64 \\
\hline 3 & 5.22 & 66 \\
\hline 3.5 & 5.34 & 64 \\
\hline 5.6 & 16.0 & 64 \\
\hline 6 & 13.0 & 65 \\
\hline 7.9 & 0.76 & 64 \\
\hline 10.3 & 0.02 & 64 \\
\hline 12.9 & 0.02 & 64 \\
\hline 15.6 & 0.02 & 64 \\
\hline 18.3 & 0.02 & 64 \\
\hline 21.1 & 1.14 & 64 \\
\hline
\end{tabular}




\subsubsection{Nitric Acid and Oxalic Acid}

As shown previously, nitric acid is very corrosive to the carbon steel waste tank. An inhibitor could be added to nitric acid to reduce its corrosivity towards carbon steel yet maintain its metal oxide dissolution efficiency. One of the properties of oxalic acid that has been observed is that the corrosion rate of carbon steel decreases with time due to the formation of a passive ferrous oxalate film. Therefore, it was hypothesized that a combination of nitric acid and oxalic acid may provide the desired outcome.

Coupon testing of carbon steel was performed in solutions of nitric acid and oxalic acid. ${ }^{79}$ Most of the testing was conducted for 3 days at ambient temperature. The general corrosion rates on carbon steel similar to that utilized for the waste tanks are shown in Table 28. Some general trends that were observed include:

1) As the oxalate concentration in the $3 \mathrm{M}$ nitric acid solutions increased, the corrosion rates also increased.

2) After 9 days in solution, the corrosion rate had decreased by a factor of nearly 3 as compared to the corrosion rate after 3 days.

3) The corrosion rate of steel in the $0.3 \mathrm{M}$ nitric acid is approximately an order of magnitude less than that observed in the $3 \mathrm{M}$ nitric acid solution.

4) The corrosion rate of steel in $0.3 \mathrm{M}$ nitric acid solutions and various compositions of oxalic acid is 2 to 4 times less than that in $0.3 \mathrm{M}$ nitric acid. The maximum rate was observed at 8 wt. \% oxalic acid, while the minimum was observed at 4 wt.\%.

Table 28 Corrosion Rates for Carbon Steel in Mixtures of Nitric and Oxalic Acid

\begin{tabular}{|l|l|r|}
\hline Solution & Material & $\begin{array}{r}\text { Corrosion } \\
\text { Rate (ipy) }\end{array}$ \\
\hline Oxalic(4\%) and Nitric (3M) & A537-CL1 & 6.30 \\
\hline Oxalic(8\%) and Nitric (3M) & A537-CL1 & 7.24 \\
\hline Oxalic(12\%) and Nitric (3M) & A537-CL1 & 8.21 \\
\hline Oxalic(4\%) and Nitric (0.3M) & A537-CL1 & 0.12 \\
\hline Oxalic(4\%) and Nitric (0.3M) & A537-CL1 & 0.13 \\
\hline Oxalic(8\%) and Nitric (0.3M) & A537-CL1 & 0.20 \\
\hline Oxalic(8\%) and Nitric (0.3M) & A537-CL1 & 0.20 \\
\hline Oxalic(12\%) and Nitric (0.3M) & A537-CL1 & 0.16 \\
\hline Oxalic(12\%) and Nitric (0.3M) & A537-CL1 & 0.15 \\
\hline Oxalic(4\%) and Nitric (3M) & A285-C & 6.09 \\
\hline Oxalic(8\%) and Nitric (3M) & A285-C & 2.62 \\
\hline Oxalic(12\%) and Nitric (3M) & A285-C & 9.00 \\
\hline Oxalic(4\%) and Nitric (0.3M) & A285-C & 0.10 \\
\hline Oxalic(4\%) and Nitric (0.3M) & A285-C & 0.11 \\
\hline Oxalic(8\%) and Nitric (0.3M) & A285-C & 0.21 \\
\hline Oxalic(8\%) and Nitric (0.3M) & A285-C & 0.19 \\
\hline Oxalic(12\%) and Nitric (0.3M) & A285-C & 0.16 \\
\hline Oxalic(12\%) and Nitric (0.3M) & A285-C & 0.17 \\
\hline
\end{tabular}

* Test performed for 9 days 
As a side reaction a significant amount of NOx was generated during testing at the high nitric acid concentrations, while none was observed at the lower nitric acid concentrations. More testing at better defined sludge removal conditions (i.e., perhaps higher temperatures, different contact times and other species present) was recommended. Depending on how much $\mathrm{NO}_{\mathrm{X}}$ is released, corrosion of carbon steel in the vapor space should also be investigated. Additionally studies that investigate sludge and fissile material dissolution in these dilute nitric acid/oxalic acid solutions are necessary.

\subsubsection{Formic Acid}

Corrosion rates of carbon steel in varying concentrations of formic acid as a function of temperature have been measured. These are shown in Table 29. ${ }^{80}$ In general corrosion rates increased with increases in formic acid concentration and temperature.

Table 29 Corrosion Rates of Carbon Steel in Formic Acid (rates in inches per year)

\begin{tabular}{|c|c|c|c|c|}
\hline $\begin{array}{c}\text { Temperature } \\
(\mathrm{C})\end{array}$ & $\begin{array}{c}5 \mathrm{wt} \% \\
\mathrm{HCOOH}\end{array}$ & $\begin{array}{c}25 \mathrm{wt} \% \\
\mathrm{HCOOH}\end{array}$ & $\begin{array}{c}50 \mathrm{wt} \% \\
\mathrm{HCOOH}\end{array}$ & $\begin{array}{c}95 \mathrm{wt} \% \\
\mathrm{HCOOH}\end{array}$ \\
\hline 20 & 0.039 & 0.016 & 0.019 & 0.04 \\
\hline 100 & 0.965 & 1.0 & 1.0 & ND \\
\hline 140 & 1.000 & $\mathrm{ND}$ & $\mathrm{ND}$ & $\mathrm{ND}$ \\
\hline
\end{tabular}

$\mathrm{ND}=$ not determined

\subsection{EFFECTS ON TANK FARM OPERATIONS}

\subsubsection{Waste Tanks}

There are several issues that must be addressed and appropriately documented in the tank farm safety analysis. A team will be formed to perform a hazard analysis on the chemical cleaning process. The hazard analysis will be used to identify safety issues related to the addition of any acid to a carbon steel tank such as corrosion, selective dissolution criticality issues, formation of energetic compounds, heat generation, hydrogen or other gas evolution, pipe pluggage and chemical handling hazards. Once identified, safety basis calculations will be performed to determine the actual hazard involved or the actual limit needed to prevent the occurrence of the problem. Appropriate administrative and engineering controls will be identified. Documents required modifying the tank farm Documented Safety Analysis (DSA) will be prepared and submitted to DOE for approval.

In addition, there are several issues related to feed quality including DWPF feed quality, Saltstone feed quality, and evaporator feed quality. Appropriate communications with these organizations will be used to ensure that the chemical cleaning process is compatible with their feed quality requirements.

\subsubsection{Evaporators}

Addition of sodium oxalate (resulting from the use and neutralization of oxalic acid as the cleaning agent) into the evaporator systems is not expected to impact the Authorization Basis 
(AB) for operating the evaporators. The sodium oxalate should have no impact on flammability, source term or criticality. The source term could be impacted if sludge remains suspended or in solution when the neutralized heel is transferred to the evaporator feed tank. The controls established in the sludge carryover program will have to be met in order to protect the source term assumptions in the $\mathrm{AB}$. The evaporator feed qualification process assumes that the ionic strength of the feed is equivalent to the sodium ion concentration. This assumption could be incorrect if significant concentrations of sodium oxalate are present, therefore additional sample analysis may be required to ensure this assumption is met.

The operability impacts may include foaming, increased pluggage or scaling. Based on literature searches and "tribal knowledge" of SRS evaporator operation, increased foaming is expected as a result of evaporator waste containing oxalates. Sodium oxalate is expected to precipitate in the evaporator system due to the high sodium concentration. If the precipitation occurs rapidly, it may be contained within the feed tank and the effect on the evaporator would be minor. If precipitation occurs more slowly, sodium oxalates could form in the evaporator itself which may lead to increased pluggage of the process piping and instrumentation lines, and accumulation of oxalate salts in the evaporator. It is anticipated that accumulation of oxalates could be removed with water flushes. Since the solubility of sodium oxalate increases with temperature, increase in sodium oxalate concentrations are not expected to lead to increased scale formation. The Saltstone WAC limit for sodium oxalate is $0.015 \mathrm{M}$ (Manual 1S, Procedure 4.01). The sodium concentration of the solution going to Saltstone during the concentration phase of ITP is $\sim 5 \mathrm{M}$. In $5 \mathrm{M}$ Na solution, the solubility limit of sodium oxalate is about $0.02 \mathrm{M}^{81}$

\subsection{EFFECTS ON DWPF}

The anticipated effects to the DWPF process are understood for four of the six cleaning agent categories. These include oxalic acid, nitric acid, formic acid, and organics. Oxalic acid is anticipated to exhibit the same behavior as that seen for the oxalate ion associated with sodium oxalate. The effects of sodium oxalate were extensively studied as part of testing for qualification of Sludge Batch 3 (SB3). The presence of the oxalate ion was shown to increase the acid demand required during Sludge Receipt and Adjustment Tank (SRAT) processing in the DWPF. ${ }^{82}$ This additional acid requirement was quantified and was shown to result in acceptable SRAT processing. ${ }^{83}$ In addition, oxalate appeared to mitigate the formation of hydrogen during both the SRAT and Slurry Mix Evaporator (SME) cycles as compared to an equivalent sludge without oxalate. ${ }^{83}$ Since oxalate can serve as a reductant, it can have an impact on the redox state of the glass in the DWPF melter.

Currently, the redox state of the glass is projected based on the expected quantities of formate and nitrate in the melter feed. The equation used to make this projection was modified to account for the presence of oxalate and was successfully shown to control the redox state of the glass. ${ }^{84}$ Glass studies with oxalate were also performed in a small melt rate furnace. Oxalate was shown to have a minimal impact on glass quality or melt behavior. ${ }^{85,86}$ Finally, since oxalate contains carbon species, the impacts on flammability in the melter had to also be considered. This was performed using the melter cold cap model for DWPF, and oxalate was shown to have minimal impact on DWPF melter flammability. ${ }^{87}$ Therefore, introducing oxalic acid into a DWPF sludge batch is not anticipated to have a detrimental impact on DWPF processing at levels equivalent to $\sim 22 \%$ oxalate anion in the sludge solids. It should also be mentioned that 
oxalic acid was proposed for cleaning the heels of tanks at West Valley. During this testing, melter testing with the resulting product was also proposed at Pacific Northwest National Laboratory (PNNL). ${ }^{88}$ If this method for cleaning is selected, researchers at PNNL should be contacted to determine the results of any melter testing performed.

The presence of oxalate ion during DWPF processing presented a criticality issue because of the concern that iron-oxalato complexes might form. The formation of these complexes would present a concern for sludges containing fissile materials since iron is the primary neutron absorber relied upon for nuclear criticality safety in DWPF sludges. SRTC studies using up to $\sim 22 \%$ oxalate ion in the sludge concluded that typical DWPF processing conditions would result in $<5 \%$ of the total iron being dissolved. If the $\mathrm{pH}$ of the material were decreased to $\sim 2$ in an accident scenario, slightly more iron would dissolve but was shown to be $<10 \%$ of the total iron present in the sludge solids. $^{89}$

Currently, the DWPF uses both nitric and formic acids in the SRAT process to chemically adjust the incoming sludge slurry. This is done to destroy nitrite, reduce mercury and manganese, neutralize the hydroxides and carbonates in the sludge, and to adjust the slurry rheology for downstream processing. DWPF analyzes the sludge to be processed, including the associated anion content, so the presence of either acid would be accounted for in the SRAT receipt sample. The amounts of each acid to add during SRAT processing would then be adjusted to account for the presence of either acid from tank cleaning. Therefore, the addition of either acid from tank cleaning would be anticipated to have minimal impact on DWPF processing.

Of the four cleaning agents with known DWPF behavior, organics as a group have the greatest impact on DWPF processing. In the SRAT, organic phases would be expected to accumulate in the condensers associated with the SRAT and in the Mercury Wash Water Tank. Conditions in the Formic Acid Vent Condenser are strongly acidic and testing has shown that dinitro organic compounds form in the presence of phenol. Similar behavior may be displayed with other organic compounds.

In addition, organics present a flammability issue in the DWPF melter and have to be accounted for in the projection of the redox conditions within the melter. If the organics were not destroyed before being fed to the melter, they could become flammable in the melter or cause the melt pool to become too reducing. Melter studies have shown that more reducing conditions can cause elemental metals or metal sulfides to precipitate in the melt pool. Organics in the former precipitate hydrolysis process were shown to form tars in several of the DWPF offgas components. Thus, several issues/concerns would have to be addressed before increased organics could be introduced into a DWPF sludge batch.

The other two cleaning agent categories, oxalic with citric acid and oxalic with hydrogen peroxide, have not been examined in previous DWPF studies. Citric acid would be anticipated to act as a reductant during DWPF operations and would have to be accounted for accordingly. Hydrogen peroxide would not be anticipated to survive the tank conditions or tank chemistry adjustments, so its impact on DWPF will be minimal. 
The Immobilization Technology Section of SRTC will be performing an extensive program to understand the effects of feed changes on DWPF melter performance. This program is to be initiated in the fall of 2003 and will consider the known DWPF feed materials. Changes to the feed materials caused by any of the tank chemical cleaning methods and the associated effects on melter processing will also need to be understood before implementation in DWPF.

\subsection{CRITICALITY AND MISCELLANEOUS SAFETY-RELATED INFORMATION}

This document does not address in detail certain safety related issues. These include preferential dissolution of poisons from the sludge, preferential formation of precipitates of fissile material (from the soluble phase), heats of reaction for various compounds, and vapor generation.

In general, criticality is a concern for all chemical cleaning agents. Each tank (or groups of tanks) must be addressed separately and its safety strategy will be dependent upon fissile material concentration and other factors. Oxalic acid has been used in previous demonstrations both at SRS and Hanford, so a safety strategy is possible.

Generation of vapors is a concern when contacting sludge heels with oxalic acid (or other agents). Data from the Tank $16 \mathrm{H}$ demonstration showed that the tank pressurized even after modification of the ventilation system. ${ }^{2}$ In the most recent Hanford demonstration of Tank C106 , it was reported that a mist-like fog formed in the tank during the first contact. It was speculated that it formed from reaction between the acid and sodium carbonate (present in high levels). The formation of the fog did not affect HEPA filter performance. 


\subsection{RECOMMENDATION}

The objective of the Waste Tank Heel Removal Chemical Cleaning Team was to collect and evaluate information available on chemical-based methods for removing residual solids from the Savannah River Site's waste tanks. As part of this study, the team was requested to develop recommendations for chemical treatments to remove residual heels (primarily sludge).

\subsection{CLEANING AGENT RECOMMENDATION}

The results of the evaluation conclusively support oxalic acid as the cleaning agent of choice for the immediate future.

The information summarized in this document indicates that differing sludge types (e.g., PUREX and HM) will have varying degrees of difficulty associated with their dissolution. Furthermore, the tank conditions that the sludge has been exposed to also affect their cleaning ability. For these reasons, the authors caution that expecting "one method fits all" is unfounded. Each tank (or at best groups of tanks with similar waste and similar historical conditioning) should be considered individually. Given that warning, oxalic acid offers the most generic application.

Oxalic acid is the best choice for a number of reasons. First, it has been widely studied and even used in several instances in the SRS HLW System and DOE complex. Its integration into the HLW system is likely the smoothest. Its effect on DWPF and the evaporators is better known. It has been shown to be effective for a wide variety of sludge types. It out performed nitric acid and other chemical cleaning agents in head to head tests. Because of its widespread use and familiarity in the DOE complex, it should be the easiest to pass regulatory, permitting, and perception concerns. Lastly, it is less corrosive than nitric acid or the combination of oxalic acid and hydrogen peroxide.

The use of nitric acid (low molarity, $\sim 0.3 \mathrm{M}$ ) should be considered in cleaning tanks slated for closing as a follow-up to oxalic acid on specific spots or mounds of solids that remain intractable to oxalic acid. The more aggressive nitric acid should provide more effective cleaning for those substances not dissolved in oxalic acid solutions. Corrosion is less of an issue since the tanks are subject to closure. However, the acceptable degree of corrosion remains unknown. If nitric acid were used, its contact should be limited (both in time and exposed surface). Use of nitric acid will require more stringent safety analyses.

The use of oxalic acid/hydrogen peroxide as a follow-up treatment to oxalic acid merits consideration for increased radioactive decontamination of waste tank surfaces. The specifics of the method should be considered on an individual application basis.

The available data does not support the use of formic acid, citric acid (with or without oxalic acid), or any other agent at this time. Formic acid, citric acid and organics are not as effective as oxalic acid in bulk dissolution of the predominant sludge components. Futhermore, these substances do not provide any "bonus" parameters or features above that provided by oxalic acid. 


\subsection{HEEL REMOVAL CHEMICAL TREATMENT CONCEPTS}

Some important general concepts about the chemical treatment of sludge heels contained in waste tanks are as follows:

1. The chemical treatment process generates a significant quantity of spent oxalic acid solution that requires neutralization. The neutralized waste solution generated then has to be handled in the tank farm. The amount of waste solution that has to be generated is directly proportional to the amount of sludge heel that is being treated. In order to minimize waste solution quantity, the heel size should be as small as practical.

2. Following bulk waste removal and prior to the first acid cleaning strike, the heel should be washed to remove soluble salts that will interfere with the dissolution of the sludge compounds. The washed heel should be dewatered as well as possible to avoid diluting the oxalic acid solution.

3. A ratio of about 20 gallons of oxalic acid solution to about 1 gallon of sludge will produce the most aggressive dissolution of sludge. The oxalic acid solution should be about $8 \mathrm{wt} \%$.

4. Although treatment at a higher acid solution temperature results in greater sludge dissolution, it is probably not practical to maintain the temperature of the slurry at an elevated temperature in the waste tank.

5. The amount of sludge dissolved will be limited by the form of the sludge compounds and by the surface area of the sludge that is exposed to fresh acid. Repeated strikes with acid solution will continue to produce significant dissolution as long as new surface is available and the form of the sludge compounds are soluble. Once either of these conditions is no longer true, the amount of sludge dissolved will decrease.

6. Agitation during the contact time will ensure that fresh solution is available to interact with the surface compounds.

7. Waste sludge characterization and lab testing for a given tank will help to minimize the volume of cleaning solution required while maximizing the degree of dissolution (and even defining the level of cleanliness required).

8. After a chemical strike, the residual contents of the tank should be re-examined to determine the probable effectiveness of an additional cleaning strike.

9. Each treatment of a waste sludge heel provides an opportunity to increase the level of knowledge about effectively dissolving sludge compounds. Sludge sampling accompanied by chemical and radiochemical analysis should be conducted with this goal in mind.

\subsection{GENERIC HEEL REMOVAL CHEMICAL TREATMENT PROCESS}

The following represents a prototypical process for heel removal assuming a well-washed and dewatered sludge heel volume of about $5 \mathrm{kgal}$. At a ratio of 20:1, approximately $100 \mathrm{kgal}$ of 8 wt $\%$ oxalic acid solution will be required. 
The oxalic acid solution should be slurried for 2 to 4 days. Approximately $70 \%$ of the residual sludge should dissolve in the first contact. A lower rate of sludge dissolution should be assumed for subsequent contacts.

The acidic solution and sludge slurry should be pumped to a receipt tank and neutralized with sufficient sodium hydroxide. During this step, it is expected that much of the dissolved sludge will reprecipitate. The new sludge solids will not have settled significantly and should be pumpable.

The cleaned tank should be sprayed with inhibited water to neutralize residual material and stabilize the tank contents to prevent the corrosion of the carbon steel.

The volumes are shown in the following table:

\begin{tabular}{|l|c|l|}
\hline Step & Volume (gal) & Notes \\
\hline Initial sludge heel & 5000 & \\
\hline $\begin{array}{l}\text { Treatment \#1 acid solution } \\
\text { addition }\end{array}$ & 100,000 & $\begin{array}{l}\text { At } 2710 \text { gallons/inch and at about } \\
30 \text { inches, } 82,000 \text { gallons will be } \\
\text { needed to run the slurry pumps. }\end{array}$ \\
\hline $\begin{array}{l}\text { Treatment \#1 slurry step } \\
\text { total volume }\end{array}$ & 105,000 & \\
\hline $\begin{array}{l}\text { Post treatment \#1 dissolved } \\
\text { phase }\end{array}$ & 103,500 & $\begin{array}{l}\text { Assuming } 70 \% \text { of the sludge } \\
\text { dissolves. }\end{array}$ \\
\hline $\begin{array}{l}\text { Post treatment \#1 solid } \\
\text { phase }\end{array}$ & 1500 & $\begin{array}{l}\text { Note that at this point about } \\
100,000 \text { gallons has been used to } \\
\text { remove } 3500 \text { gallons of sludge. } \\
\text { This is a ratio of about 30 gallons } \\
\text { of water per gallon of sludge } \\
\text { removed. }\end{array}$ \\
\hline $\begin{array}{l}\text { Transfer to receipt tank } \\
\text { Post treatment \#1 sludge } \\
\text { heel }\end{array}$ & 1500 & \\
\hline
\end{tabular}

\subsection{PATH FORWARD}

The above recommendation to use oxalic acid should not be considered as a conclusion to this area of research. The authors recommend that a small task be maintained to annually evaluate new cleaning agents or additional information on existing cleaning agents and to test the more promising cleaning agents. In addition, laboratory scale testing should be conducted if nitric acid or hydrogen peroxide agents are deemed suitable. Minimal testing at tank conditions have been performed to support these agents. Testing, in general, will assist in refining quantities and expectations. 


\subsection{REFERENCES}

1 “Savannah River Site High Level Waste System Plan,” HLW-2002-00025, Revision 13, March 2002.

${ }^{2}$ W. L. West, "Tank 16 Demonstration - Water Wash and Chemical Cleaning Results," DPSP80-17-23, December 16, 1980.

3 "Closure Business Unit Waste Characterization System (WCS) 1.5 - Functional Performance Requirements and Design Specification,” B-RS-H-00118, March 2003.

${ }^{4}$ G. K. Georgeton and J. R. Hester, "Characterization of Radionulides in HLW Sludge Based on Isotopic Distribution of Irradiated Assemblies," WSRC-TR-94-0562, Rev. 1, Savannah River Site.

${ }^{5}$ M. C. Chandler, "Fresh Waste Receipts to the Waste Tanks," WSRC-TR-94-0191, Savannah River Plant, October 1994.

${ }^{6}$ W. S. Cavin, WSRC-TR-93-135, Separations Waste Sludge Spreadsheet (U), WSRC-TR-93$135,7 / 28 / 93$.

${ }^{7}$ W. S. Cavin and A. T. Crumm, "Fresh Waste Receipts( U)," WSRC-TR-93-426, 1/24/94.

${ }^{8}$ F. G. McNatt, and E. W. Stevens, "History of Waste Tank 1, 1954 through 1974," DPSPU-7811-8, Savannah River Plant, October 1978.

${ }^{9}$ A. Q. Goslen and D. K. McGuire, "History of Waste Tank 2, 1955 through 1974," DPSPU-8311-5, Savannah River Plant, December 1983.

${ }^{10}$ A. Q. Goslen and D. K. McGuire, "History of Waste Tank 3, 1955 through 1974," DPSPU83-11-9, Savannah River Plant, December 1983.

${ }^{11}$ A. Q. Goslen and D. K. McGuire, "History of Waste Tank 4, 1959 through 1974,” DPSPU80-11-10, Savannah River Plant, July 1981.

12 Annual Radioactive Waste Tank Inspection Program-2002, WSRC-TR-2003-00175, June 2003, Rev. 0

${ }^{13}$ W. S. Cavin and A. T. Crumm, "Waste Transfers and Miscellaneous Additions(U)," WSRCTR-93-425, 1/25/94.

${ }^{14}$ C. J. Thomas, and R. Ronnett, "History of Waste Tank 5," DPSPU-81-11-10, Savannah River Plant, July 1981.

${ }^{15}$ C. J. Thomas and R. Ronnett, "History of Waste Tank 6, 1954 through 1974," DPSPU-81-114, Savannah River Plant, March 1981. 
${ }^{16}$ D.W. Tharin and D.R. Lohr, "History of Waste Tank 9, 1955 through 1974," Sep (WM)175, Savannah River Plant, March 1976.

${ }^{17}$ T. L. Davis, D.W. Tharin, and W. E. Stevens, "History of Waste Tank 10, 1955 through 1974,’ DPSPU-78-11-11, Savannah River Plant, October 1978.

18 T. L. Davis, D.W. Tharin, and D.R. Lohr, "History of Waste Tank 11, 1955 through 1974," DPSPU-78-11-12, Savannah River Plant, October 1978.

${ }^{19}$ T. L. Davis, D. W. Tharin, and D. R. Lohr, "History of Waste Tank 12, 1956 through 1974," DPSPU-78-11-9, Savannah River Plant, September 1978.

${ }^{20}$ D. W. Tharin, and D. R. Lohr, "History of Waste Tank 13, 1956 through 1974," DPSPU-7811-2, Savannah River Plant, June 1978.

${ }^{21}$ T. L. Davis, D.W. Tharin, and D. R. Lohr, "History of Waste Tank 14, 1957 through 1974," DPSPU-78-11-19, Savannah River Plant, August 11977.

${ }^{22}$ T. L. Davis, D. W. Tharin, H. D. W. Jones, and D. R. Lohr, "History of Waste Tank 16, 1959 through 1974,” DPSPU-77-11-17, Savannah River Plant, July 1, 1992.

${ }^{23}$ F. G. Mcnatt and D. W. Tharin, "History of Waste Tank 17, 1961 through 1974," WSRC-TR92-191, Savannah River Plant., January 1, 1992.

${ }^{24}$ A. Q. Goslen, “Tank 19 Salt Removal,” DPSP-84-17-7, Savannah River Plant, August 1986.

${ }^{25}$ F. G. McNatt, "History of Waste Tank 20, 1959 through 1974,” DPSPU-82-11-10, Savannah River Plant, July 1982.

${ }^{26}$ F. G. McNatt, "History of Waste Tank 21, 1961 through 1974,” DPSPU-789-11-1052, Savannah River Plant, October 1978.

${ }^{27}$ F. G. McNatt, "History of Waste Tank 22, 1965 through 1974,” DPSPU-79-11-52, Savannah River Plant, April 1979.

${ }^{28}$ F. G. McNatt, “History of Tank 23, 1962 through 1974,” DPSPU-79-11-7, Savannah River Plant, April 1979.

${ }^{29}$ F. G. McNatt, "History of Waste Tank 24, 1962 through 1974," DPSPU-79-11-2, Savannah River Plant, April 1979.

${ }^{30}$ M. R. Poirier and S. D. Fink, "Investigation of Alternative Approaches for Cleaning Mott Porous Metals Filters,” November 12, 2002, WSRC-TR-2002-00526, Rev. 0. 
${ }^{31}$ R. F. Bradley and A. J. Hill, Jr., "Chemical Dissolving of Sludge from a High Level Waste Tank at the Savannah River Plant," March 1977, DP-1471.

${ }^{32}$ E. W. Holtzscheiter, "Digestion and Settling Experiments with Sludge Samples From Tank 16H," April 4, 1979, DPST-79-332.

${ }^{33}$ M. C. H. Fong, “Oxalic Acid Cleaning of Tank 24H,” September 9, 1985. DSPT-85-782.

${ }^{34}$ D. B. Bechtold, G. A. Cooke, D. L. Herting, J. C. Person, R. S. Viswanath, and R. W. Warrant, "Laboratory Testing of Oxalic Acid Dissolution of Tank 241-C-106 Sludge," July 10, 2003, RPP-17158, Rev. 0. Fluor Hanford, Richland WA 99352.

${ }^{35}$ E. J. Weber, “Aluminum Hydroxide Dissolution in Synthetic Sludges,” DP-1617, March 1982.

${ }^{36}$ N. E. Bibler, " $\mathrm{H}_{2} \mathrm{O}_{2}-\mathrm{H}_{2} \mathrm{C}_{2} \mathrm{O}_{4}$ Solutions for Cleaning Inside Surfaces of SRP Waste Tanks," March 10, 1981, DPST-81-308.

${ }^{37}$ C. J. Coleman, N. E. Bibler, D.M. Ferrara, and S.F. Siegwald, "Reaction of Formic and Nitric Acids with Savannah River Site Radioactive HLW Sludge in the DWPF Pretreatment Steps," Proceedings of Nuclear and Hazardous Waste Management - Spectrum 94, pp 737-741, August 1994.

${ }^{38}$ R. E. Eibling, "Results of Mercury Reduction with Formic Acid," DPST-83-1047, December $1,1983$.

${ }^{39}$ C. W. Hsu, "Formic Acid Requirement in the DWPF Chemical Processing Cell," WSRC-RP90-0554, July 5, 1990.

${ }^{40}$ T. L. Fellinger, D. T. Hobbs, M. G. Bronikowski, B.C. Hill, and J.H. Gray, "Demonstration of the Tank Farm Washing Process and the DWPF SRT Cycle with Sludge Batch 3 Simulant and Precipitated Pu/Gd Mixture from H-Canyon Tank 18.3," WSRC-TR-2002-00208, May 8, 2002.

${ }^{41}$ C. C. Herman, D. C. Koopman, N. E. Bibler, D. R. Best, and M. F. Williams, "SRAT Processing of Sludge Batch 3 Simulant to Evaluate Impacts of H-Canyon Slurry Containing Precipitated Pu and Gd," WSRC-TR-2002-00322, July 25, 2002.

${ }^{42}$ K. N. Nash, A. V. Gelis, M. P. Jensen, A. H. Bond, J. C. Sullivan, L. Rao and A. Garnov, "Actinides in Alkaline Media: Dissolution, Mineral Associations, and Speciation in Hanford Waste Tank Sludge Simulants," Nuclear Science and Technology, Supplement 3, 512-515 (2002). LBNL-49979.

${ }^{43}$ C. E. Pickett, and R. A. L. Eubanks, "221-F \& H Separations Processes Summary of Liquid Radioactive waste Reductions Made Through Process Improvement," OPS-STH-89-0177, December 27, 1989. 
${ }^{44}$ H. Rumpf, and W. A. Knepper (editor), Agglomeration, Interscience, New York, 1962, p. 379.

${ }^{45}$ K. Wefers, and, C. Misra, "Oxides and Hydroxides of Aluminum," Alcoa Technical Paper \#19, Revised, Alcoa Laboratories 1987.

${ }^{46}$ F. Fondeur, "Elemental Analysis of 'Washed' Tank 8F Slurry Simulant," SRT-LWP-200200071, July, 2002.

${ }^{47}$ R. H. Perry, C. H. Chilton, and S. D. Kirkpatrick, Chemical Engineers Handbook, Fourth Edition, McGraw-Hill, 1963.

${ }^{48}$ A. J. Hill, Jr., Waste Tank Retirement Neutralization of Oxalic Acid Technical Data," DPST78-263, March 7, 1978.

${ }^{49}$ T. Grewer, D. J. Frurip, and B. K. Harrison, "Prediction of Thermal Hazards of Chemical Reactions," Journal of Loss Prevention in the Process Industries, 12, pp. 391-398, (1999).

${ }^{50}$ Pfizer Chemicals Division Technical Bulletin No. 43, "Oxalic Acid and Its Salts," March 1968.

${ }^{51}$ S. Banwart, S. Davies, and W. Stumm, "The Role of Oxalate in Accelerating the Reductive Dissolution of Hematite $\left(\alpha-\mathrm{Fe}_{2} \mathrm{O}_{3}\right)$ by Ascorbate," Colloids Surfaces, 39, (1989), pp 303-309.

${ }^{52}$ G. J. Houben, "Iron Oxide Incrustations in Wells. Part 2: Chemical Dissolution and Modeling," Applied Geochemistry, 18, (2003), pp 941-954.

${ }^{53}$ E. J. Weber, "Aluminum Hydroxide Dissolution in Synthetic Sludges," DP-1617, UC-70, March 1982.

${ }^{54}$ J. K. Klewicki, and J. J. Morgan, "Dissolution of $\beta-\mathrm{MnOOH}$ particles by Ligands: Pyrophosphate, Ethylenediaminetetracetate, and Citrate," Cheochimica et Cosmochimica Acta, 63, (1999), pp. 3017-3024.

${ }^{55}$ A. G. Xyla, B. Sulzberger, G. W. Luther, J. G. Hering, P. VanCapellen, and W. Stumm, “ Reductive Dissolution of Manganese (III,IV) (hydr)oxides by Oxalate: The Effect of $\mathrm{pH}$ and Light," Langmuir, 8, (1992), pp 95-103.

${ }^{56}$ J. K. Klewicki, and J. J. Morgan, "Dissolution of $\beta-\mathrm{MnOOH}$ Particles by Ligands: Pyrophosphate, EDTA, and Citrate," Geochimica et Cosmichimica Acta, 63, No 19/20, (1999), pp. 3017-3024.

${ }^{57}$ A. T. Stone, and J. J. Morgan, "Reduction and Dissolution of Manganese (III) and Manganese (IV) Oxides by Organics: 2. Survey of the Reactivity of Organics," Environ. Sci. Technolo., 18 (1984), pp 617-624. 
${ }^{58}$ A. G. Kumbhar, K. Kishore, and G. Venkateswaran, "Dissolution of Ce, Zr, and LaContaining Magnetites and Nickel Ferrite in Citric Acid-EDTA-Gallic Acid Formulation," Hydrometallurgy, 68(2003), pp. 171-181.

${ }^{59}$ W. R. Wilmarth, S. D. Fink, D. T. Hobbs, and M. S. Hay, "Characterization and Dissolution Studies of Samples from the 242-16H Evaporator Gravity Drain Line (U),” WSRC-TR-97-0326, October 1997.

${ }^{60}$ M. Thompson, C. Boley, and W. R. Wilmarth, "2H Evaporator Chemical Cleaning," Presentation to the "Plan of the Week" on June 21, 2000.

${ }^{61}$ C. W. Francis, M. E. Timpson, and J. H. Wilson, “ Bench- and Pilot-scale Studies Relating to the Removal of Uranium from Uranium-contaminated Soils using Carbonate and Citrate Lixiviants," Journal of Hazardous Materials 66 (1999), pp 67-87.

${ }^{62}$ G. J. Houben, "Iron Oxide Incrustation in Wells. Part 2: Chemical Dissolution and Modeling," Applied Geochemistry 18, (2003), 941-954.

${ }^{63}$ R. N. Sahoo, P. K. Naik, and S. C. Das, "Leaching of Manganese From Low-Grade Manganese Ore Using Oxalic Acid as Reductant in Sulphuric Acid Solution," Hydrometallurgy, 62(2001), 157-163.

${ }^{64}$ R. S. Ondrejcin, "Carbon Steel and Stainless Steel Attack from Sludge Dissolution," DPST76-471, December 15, 1976.

${ }^{65}$ E. W. Wilde, et.al., “Cleaning Agents for Reactor Heat Exchangers,” DP-1670, March, 1984.

${ }^{66}$ H. D. Smith, R. L. Russell, and G. K. Patello, "Evaluation of Hydrogen Gas Generation from Oxalic Acid Contact with the Carbon Steel of a High Level Waste Storage Tank," in Environmental Issues and Waste Management Technologies in the Ceramic and Nuclear Industries, Eds. J. C. Marra and G.T. Chandler, Ceramic Transactions, Vol. 93, pp. 221-227, 1999.

${ }^{67}$ R. A. Speranzini, et. al., Materials Performance, pp. 67-72, February 1989.

${ }^{68}$ L. Chen, et. al., "A Survey of Decontamination Processes Applicable to DOE Nuclear Facilities,” ANL-97/19, pp. 27-28, 1997.

${ }^{69}$ D. B. Bechtold, "Study of Radionuclide Leaching from the Residues of K Basin Sludge Dissolution,” HNF-2917, July 30, 1998.

${ }^{70}$ C. P. Dillon, Corrosion Control in the Chemical Process Industries, $2{ }^{\text {nd }}$ Ed., NACE International, Houston, TX, p. 256, 1994. 
${ }^{71}$ Report on Tank Retrieval and Closure Demonstration, Scientific Technology Center Mining and Chemical Combine, Russia, 2000.

${ }^{72}$ M. R. Elmore, et. al., "Fiscal Year 1995 Laboratory Scale Studies of Cs Elution in Tank 8D-1 and Sludge Dissolution in Tank 8D-2," PNNL-10945, April 1996.

${ }^{73}$ M. R. Elmore, "Corrosion of Mild Steel in Simulated Cesium Elution Process Solutions," PNNL-11284, September 1996.

${ }^{74}$ M. S. Abdel Aal, et. al., Materials, Chemistry and Physics, Vol. 39, pp. 290-297, 1995.

${ }^{75}$ Kirk-Othmer Encyclopedia of Chemical Technology, Vol, 6, 4 ed. 1993, p. 354.

${ }^{76}$ N. D. Tomashov, "Theory of Corrosion and Protection of Metals," The MacMillan Company, New York, NY, pp. 511-513, 1966.

${ }^{77}$ U. R. Evans, "Behavior of Metals in Nitric Acid," in Trans. Faraday Society. Vol. 40, pp. 120130, 1944.

${ }^{78}$ H. H. Uhlig, "Corrosion Handbook," The Electrochemical Society, New York, NY, pp. 133$134,1948$.

${ }^{79}$ B. J. Wiersma and K. H. Subramanian, "Corrosion Testing of Carbon Steel in Acid Cleaning Solutions,” WSRC-TR-2002-00427, September 2002.

${ }^{80}$ Process Industries Corrosion, B. J. Moniz and W. I. Pollock, Eds., NACE International, Houston, TX, pp. 385-386, 1986.

${ }^{81}$ G. A. Taylor, "High Level Waste Engineering, Managing Spent Sodium Oxalate from Waste Removal," WSRC-TR-96-0326, November 21, 1996, Rev. 0.

${ }^{82}$ D.C. Koopman, C. M. Jantzen, and T. B. Edwards, "Acid Addition Stoichiometry for Sludge Batch 3 Processing in the Defense Waste Processing Facility," WSRC-TR-2003-00118, February 27, 2003.

${ }^{83}$ C. C. Herman, D. R. Best, D. C. Koopman, and M. F. Williams, "Sludge Batch 3 Simulant Flowsheet Studies: Phase I SRAT Results,” WSRC-TR-2003-00088, March 20, 20023.

${ }^{84}$ C. M. Jantzen, J. R. Zamecnik, D. C. Koopman, C. C. Herman, and J. B. Pickett, "Electron Equivalents Model for Controlling Reduction-Oxidation (Redox) Equilibrium during High Level (HLW) Vitrification,” WSRC-TR-2003-00126, March 31, 2003

${ }^{85}$ T. H. Lorier, D. K. Peeler, D. C. Koopman, and T. B. Edwards, "Sludge Batch 3 Melt Rate Assessment," WSRC-TR-2003-00027, January 23, 2003. 
${ }^{86}$ M. E. Smith, C. C. Herman, and T. H. Lorier, "Sludge Batch 3 (Decant \#5)/Frit 202 Flowsheet Demonstration," WSRC-TR-2003-00138, March 31, 2003.

${ }^{87}$ A. S. Choi, "DWPF Melter Offgas Flammability Assessment for Sludge Batch 3," SRT-PDH2003-00007, February 24, 2003.

${ }^{88}$ G. K. Patello, R. L. Russell, G. R. Golcar, H. D. Smith, G. L. Smith, and M. L. Elliott, "Processing Simulated Oxalated High Level Waste Through a Vitrification Feed Preparation Flowsheet," Environmental Issues and Waste Management Technologies in the Ceramic and Nuclear Industries IV, J.C. Marra and G.T. Chandler, eds., American Ceramic Society, Westerville, Ohio, Ceramic Transactions Volume 93.

${ }^{89}$ C. C. Herman and D. R. Best, "Supplemental Solubility Data for SRAT Processing of Sludge Batch 3 with H-Canyon Slurry Containing Precipitated Pu and Gd in DWPF," WSRC-TR-200200508, November 15, 2002. 